\title{
Floristic, vegetational and
} geographic characteristics of the Sierra de Chiconquiaco, Veracruz, Mexico

\section{creative commons}

Botamical Sciences 95 (4): 610-659, 2017

DOI: 10.17129/botsci.1111

Received:

December 1st, 2016

Accepted:

April 4th, 2017

Associate Editor

Juan Nuñez Farfán
Copyright: (c) 2017 Lascurain-Rangel et al. This is an open access article distributed under the terms of the Creative Commons Attribution License, which permits unrestricted use, distribution, and reproduction in any medium, provided the original author and source are credited.

${ }^{1}$ Instituto de Ecología, A.C. Red Ambiente y Sustentabilidad, Mexico.

2 Instituto de Ecología, A.C. Herbario XAL, Mexico.

${ }^{3}$ Facultad de Biología.

Universidad Veracruzana, Mexico.

${ }^{4}$ Instituto de Ecología, A.C. Red Ecología Funcional, Mexico.

${ }^{5}$ Instituto de Ecología, A.C. Unidad de Servicios Profesionales Altamente Especializados, Mexico.

${ }^{6}$ Universidad Autónoma de Campeche, Mexico.

* Corresponding author: maite.lascurain@inecol.mx

\author{
Maite Lascurain-Rangel ${ }^{1 *}$, Sergio Avendaño-Reyes², Miguel Cházaro- \\ Basañez ${ }^{3}$, Daniel Geissert-Kientz ${ }^{4}$, Rafael Villegas-Patraca ${ }^{5}$, César \\ Augusto Gallo-Gómez ${ }^{5}$ y Celso Gutiérrez-Báez ${ }^{6}$
}

\section{Abstract}

Background: Explored botanically from the 19th century, the Sierra de Chiconquiaco is recognized for its large vegetal and topographical heterogeneity. However, the available floristic information is sparse and its geographic characteristics remain undefined. The objective of this study was therefore to integrate floristic, vegetal and geographic information in order to identify areas that have experienced floristic exploration as well as potential sites for conservation.

Question: Under which criteria can the Sierra be geographically delimited? What kind of floristic and vegetational studies have been carried out? How many species of plants have been registered? Which sites have been more widely explored? Which of them have conservation and research potentials?

Study site and years of study: Sierra de Chiconquiaco, Veracruz, Mexico, 2010-2014.

Methods: A bibliographical and records review of the XAL and MEXU herbariums, works and field survey were carried out. Through analysis of geomorphological attributes in a geographic information system, the boundaries of the Sierra were established, revealing an area of $3,632 \mathrm{~km}^{2}$, featuring 22 municipalities and an altitudinal range of 50 to $3,000 \mathrm{~m}$ a.s.1.

Results: Seven vegetation types were described, as well as a floristic list of 3,016 species, including 72 type localities, 36 endemics, 57 registered in the NOM-059, 2010 and 195 in the CITES.

Conclusions: Nine potential areas for conservation of flora were detected, as well as six that were scarcely documented in the herbaria. This study provides a relevant contribution to the knowledge, use and conservation of the vegetal resources of Mexico.

Key words: floristic inventory, vegetational, botanic collections, geographic delineation, conservation zones.

\section{Florística, vegetación y características geográficas de la Sierra de Chiconquiaco, Veracruz, México \\ Resumen}

Antecedentes: Explorada botánicamente desde el siglo XIX, la Sierra de Chiconquiaco destaca por su amplia heterogeneidad vegetal y topográfica. Sin embargo, la información florística disponible era dispersa y sus características geográficas indefinidas. Por este motivo, el objetivo de este estudio fue llevar a cabo una síntesis geográfica, florística y de vegetación, con el fin de identificar áreas exploradas florísticamente y sitios con potencial para la conservación.

Preguntas: ¿Bajo qué criterios se delimita geográficamente a la Sierra? ¿Qué estudios florísticos y de vegetación se han llevado cabo? ¿Cuántas especies de plantas se registran? ¿Cuáles sitios son más explorados?

Sitio de estudio y fechas: Sierra de Chiconquiaco, Veracruz, Mexico, 2010-2014.

Métodos: Registros de los herbarios XAL y MEXU, trabajos de campo. Mediante el análisis de atributos geomorfológicos en un sistema de información geográfica, se establecieron los límites de la Sierra, que abarca una extensión de $3,632 \mathrm{~km}^{2}, 22$ municipios y un intervalo altitudinal de 50 a 3,000 m s.n.m.

Resultados: Siete tipos de vegetación, una lista florística de 3,016 especies, que incluye 72 localidades tipo, 36 endémicas, 57 registradas en la NOM-059, 2010 y 195 en CITES.

Conclusiones: Se detectaron nueve áreas potenciales para la conservación de la flora y seis escasamente documentadas en los herbarios. Este estudio contribuye al conocimiento, uso y conservación de los recursos vegetales del país.

Palabras clave: inventario florístico, vegetación, colecciones botánicas, delimitación geográfica, zonas de conservación. 
loristic inventories and studies of vegetation are necessary in order to evaluate the plant diversity of a region, formulate actions of restoration, determine the risk category status of species and provide data pertaining to land use, conservation, environmental impact and fragmentation (Prance 1977, Bojórquez-Tapia et al. 1994, Norris et al. 2001, Villaseñor 2003, Jayakumar et al. 2011).

The Sierra de Chiconquiaco, also known as the Sierra de Misantla or Sierra de Naolinco, is a region in Mexico where the information generated by the botanic collections, floristic inventories and vegetation studies since the $19^{\text {th }}$ century, has never been effectively integrated. This is despite the fact that, from a biogeographic perspective, it is a critical zone in terms of the distribution of many tropical tree genera, particularly in the lowlands (Gómez-Pompa 1966). There have been two important floristic and vegetation studies carried out in the Sierra. One was presented by Gómez-Pompa (1966), who describes the area as a "region of 1,500 km², artificially circumscribed to the north by the Martínez de la Torre to Nautla road, parallel to the Nautla river, to the east by the Gulf of Mexico, to the west by the Martínez de la Torre to Misantla road and to the south by the Sierra de Chiconquiaco. This author describes the following vegetation types and plant associations: deciduous forest, tropical sub-perennial high forest (including forests of species of Lauraceae, Pseudolmedia glabrata (Liebm.) C.C. Berg. and Brosimum alicastrum $\mathrm{Sw}$. and riparian forest); oak forests (several types) and mangroves. Similarly, the author conducted a taxonomic and ecological analysis of the trees and shrubs, including the most important plant families of that area. The other important reference is by Gutiérrez-Baez (1993), who studied the vegetation in nine municipalities $\left(525 \mathrm{~km}^{2}\right)$. His work indicates that this region presents topographic heights featuring pine forests $(2,100-2,500 \mathrm{~m}$ a.s.1.), intermediate areas with deciduous forest $(1,100-2,100 \mathrm{~m}$ a.s.l.) and lowlands with tropical high sub-evergreen forest (400-1,100 $\mathrm{m}$ a.s.1.).

The Sierra de Chiconquiaco is considered a refuge for a wide diversity of plant species, belonging to different communities, including many useful plants (Gómez-Pompa 1966, Gutiérrez-Báez 1994, Zamora-Crescencio \& Avendaño-Reyes 1998, Ambrosio-Montoya \& Avendaño-Reyes 1999, Lascurain-Rangel et al. 2013, López-Acosta et al. 2014). However, according to the data of land use and vegetation of the Serie V (INEGI 2013), pastures occupy increasingly large areas providing clear evidence of land use changes that put conservation of the forest ecosystems at risk (Ellis \& Martínez-Bello 2010).

Despite the fact that the Sierra de Chiconquiaco has been mentioned in different studies (López-Infanzón 1991, Gutiérrez-Báez 1993, Ferrari et al. 2005), no clear geographic delineation is available, which complicates the location and analysis of the distribution of floristic and vegetal resources present in the area. The first official reference is presented by the Carta Estatal de Regionalización Fisiográfica (INEGI 1988), in which the Subprovince 14 Chiconquiaco is identified and mapped at a scale of 1:1,000,000 as a division of the Province X-Volcanic belt. This subprovince features different landform systems, such as mountains, low hills, plateaus and valleys as the most important. However, its geographic boundary extends towards the south and thus includes the low part and the piedmont of the Cofre de Perote-Pico de Orizaba mountain range, from Xalapa-Actopan to Huatusco, which do not belong to the Sierra de Chiconquiaco.

The general objective of this study was therefore to summarize geographic and floristic information from the vegetation and botanic collections from the Sierra de Chiconquiaco. The specific objectives were: a) to propose its geographical delineation based on landform criteria; b) to integrate the floristic and vegetation studies that have been conducted to date; c) to produce a list of plant species from the records of herbarium databases, including those of type locality, endemics and those registered in the NOM-059 SEMARNAT 2010, d) to identify priority sites with little history of botanic exploration and e) to propose potential sites for conservation and research.

\section{Materials and methods}

Study area. The Sierra de Chiconquiaco is a montane massif that traverses the coastal plain of the Gulf of Mexico from west to east, at latitude $19^{\circ} \mathrm{N}$. The name Chiconquiaco comes from the Náhuatl Chikon-kiaho-ko meaning "in the seven rains", the name given by the indigenous 
Totonac people in honor of the god of the storms. It is also the name of a municipality and settlement, located in the central part of the montane massif. From a biogeographic perspective, its vegetation belongs to the Holarctic realm, to the Mesoamerican Montane region and to the Sierras Meridionales floristic province. The coastal area corresponds to the Neotropical realm, to the Caribbean floristic region and to the province of the Gulf of Mexico coast (Rzedowski 1978), which extends in a continuous strip along the coast of the states of Veracruz and Tabasco, as well as some adjacent low portions of Tamaulipas, San Luis Potosí, Hidalgo, Puebla, Oaxaca, Chiapas and Campeche (Morrone 2005).

Delineation and zonation. Delineation of the Sierra de Chiconquiaco is based on morpho-structural features derived from the state physiographic regionalization (INEGI 1988) and from the geomorphological regionalization of Veracruz (Geissert 1999). In general, it was established delimited to the north by the fluvial plain of the Nautla river, to the northeast, east and southeast by the coastal plain of the Gulf of Mexico, to the south by the tectonic depression of Actopan and to the west by the canyon of the Bobos river. The precise boundary was traced manually on a shaded relief model produced from the DEM "Continuo de Elevaciones Mexicano 3.0" of INEGI (2015). Hydrological characterization was conducted with the information of the Conjunto de Datos Vectorial Hidrológico of INEGI (1999), climatic characterization with the Conjunto de Datos Vectorial Climático of INEGI (2000) and soil characterization with the Conjunto de Datos Vectorial Edafológico of INEGI (2007).

Geomorpho-geological zonation of the Sierra of Chiconquiaco was also conducted from the Continuo de Elevaciones Mexicano 3.0, using ArcGis Desktop 10.2. This continuum of elevations is constantly updated and, unlike other elevation models (SRTM-NASA, ASTER GDEMMETI), its spatial resolution of 15 meters per pixel provides greater detail. The landforms were obtained following Priego et al. (2003), based on the vertical dissection of the relief. The values were re-categorized into three landform types: steep mountainous $\left(>400 \mathrm{~m} / \mathrm{km}^{2}\right)$, gentle mountainous $\left(100-400 \mathrm{~m} / \mathrm{km}^{2}\right)$ and hills and minor elevations $\left(40-100 \mathrm{~m} / \mathrm{km}^{2}\right)$. The map of slopes was derived from the same continuum of elevations and featured four slope classes: low $\left(<5^{\circ}\right)$, moderate $\left(5-20^{\circ}\right)$, steep to very steep $\left(20-45^{\circ}\right)$ and abrupt $\left(>45^{\circ}\right)$. The geological information came from the Conjunto de Datos Vectorial Geológico by INEGI (1986). To create the partial maps that led to the final results, the following ArcGis tools were used: Create Fishnet, Dissolve, Interpolate to raster, Clip, Intersect, Eliminate, Smooth polygon and Slope. For the definitive geomorpho-geological zonation, the minimum mapping unit criterion was applied, which consists of only representing polygons greater than 500 ha. The cartography and inputs were processed in Projection UTM Zone 14 Q.

Floristic and vegetation studies. The type localities, presence of $19^{\text {th }}$ century collectors, floristic and vegetation studies, endemics and species registered in the NOM-059 SEMARNAT (2010) were identified with bibliographic support. Databases of the herbarium XAL and MEXU were chosen to generate a floristic list of species within an altitudinal range of 50 to $3,000 \mathrm{~m}$ a.s.l., since they contain information from many collections in the study zone. A raster map of density of points or sites was obtained from the geographic coordinates of the collections, as well as areas that presented the least historical collection effort.

\section{Results and discussion}

Geographic characteristics. The polygon of the Sierra of Chiconquiaco presents in its central part a variable length of 70-75 km (east-west) and a width of 50-55 km (north-south) covering an area of $3,632 \mathrm{~km}^{2}$. The maximum altitude is close to $3,000 \mathrm{~m}$ a.s.l. in the central portion, while the minimum is between 35 and $50 \mathrm{~m}$ a.s.l. adjacent to the peripheral coastal plain. The municipalities of Acatlán, Chiconquiaco, Coacoatzintla, Colipa, Juchique de Ferrer, Landero y Coss, Miahuatlán, Misantla, Naolinco, Tatatila, Tenochtitlan, Tepetlán, Tlacolulan, Tonayán and Yecuatla, as well as part of the municipalities of Actopan, Alto Lucero, Altotonga, Atzalan, Nautla, Martínez de la Torre and Vega de Alatorre (Figure 1).

Topography of the central-western sector (11\% of the area) comprises steep slopes of 20 to $\geq$ 
Figure 1. Map of the Sierra de Chiconquiaco and municipalities.
Figure 2. Slope gradient in the Sierra of Chiconquiaco. 1) Low $<5^{\circ}$; 2) Moderate $5-20^{\circ}$; 3) Steep $20-45^{\circ}$; 4) Abrupt $>45^{\circ}$.

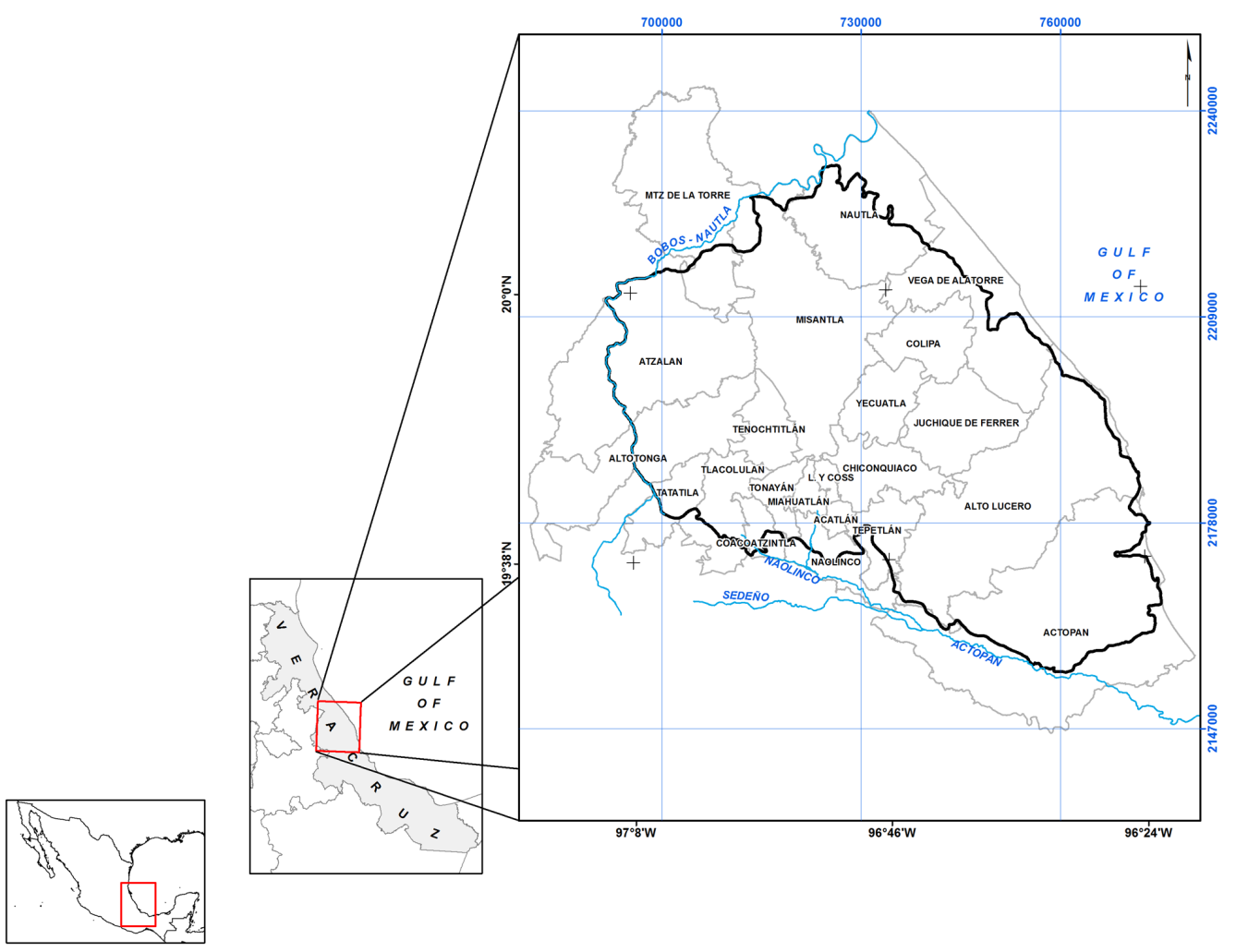

$45^{\circ}$ with relative heights of over $600 \mathrm{~m}$ (Figure 2). This is the result of destruction by PlioceneQuaternary fluvial erosion of upper Tertiary age andesitic and basaltic lava flows and pyroclastic flows (breccia). As a result, deep ravines were excavated in the northern mountainside, while the Quaternary lava flows on the southern side protected the topography from fluvial dissection (Geissert-Kientz 1999).

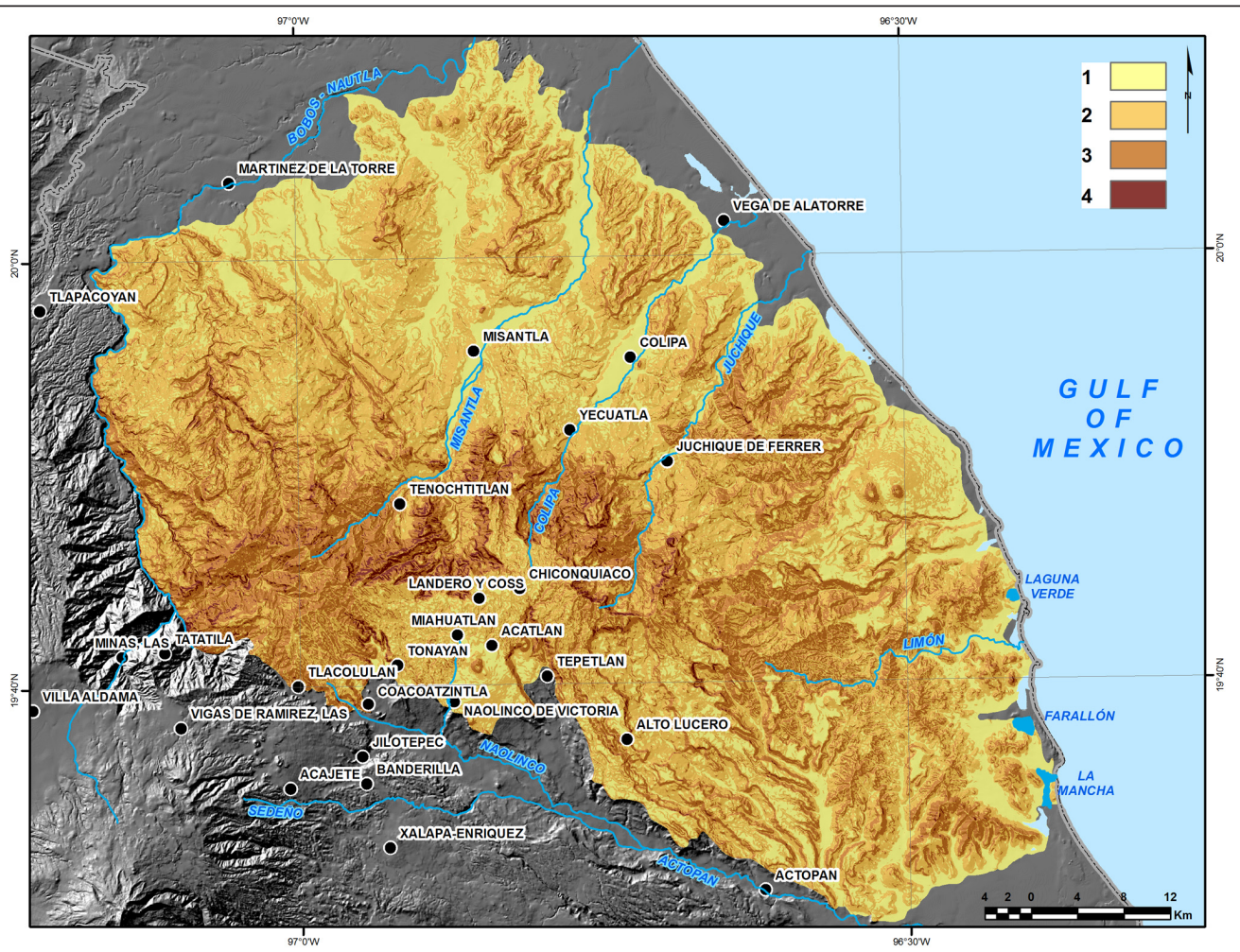


Figure 3. Landforms and geology of the slopes, sedimentary rocks, limestone; 2 Steep slopes, igneous extrusive rocks; 3 Moderate slopes, sedimentary rocks, sandstone; 4 Moderate slopes, sedimentary rocks, limestone; 5 Moderate slopes, igneous extrusive rocks; 6 Hills and minor elevations, sedimentary rocks, limestone; 7 Hills and minor elevations, sedimentary rocks, limestone- alluvial plain; 8 Hills and minor elevations, sedimentary rocks, conglomerate; 9 Hills and minor elevations, igneous extrusive rocks and 10 Hills and minor elevations, igneous extrusive rocks- alluvial plain.

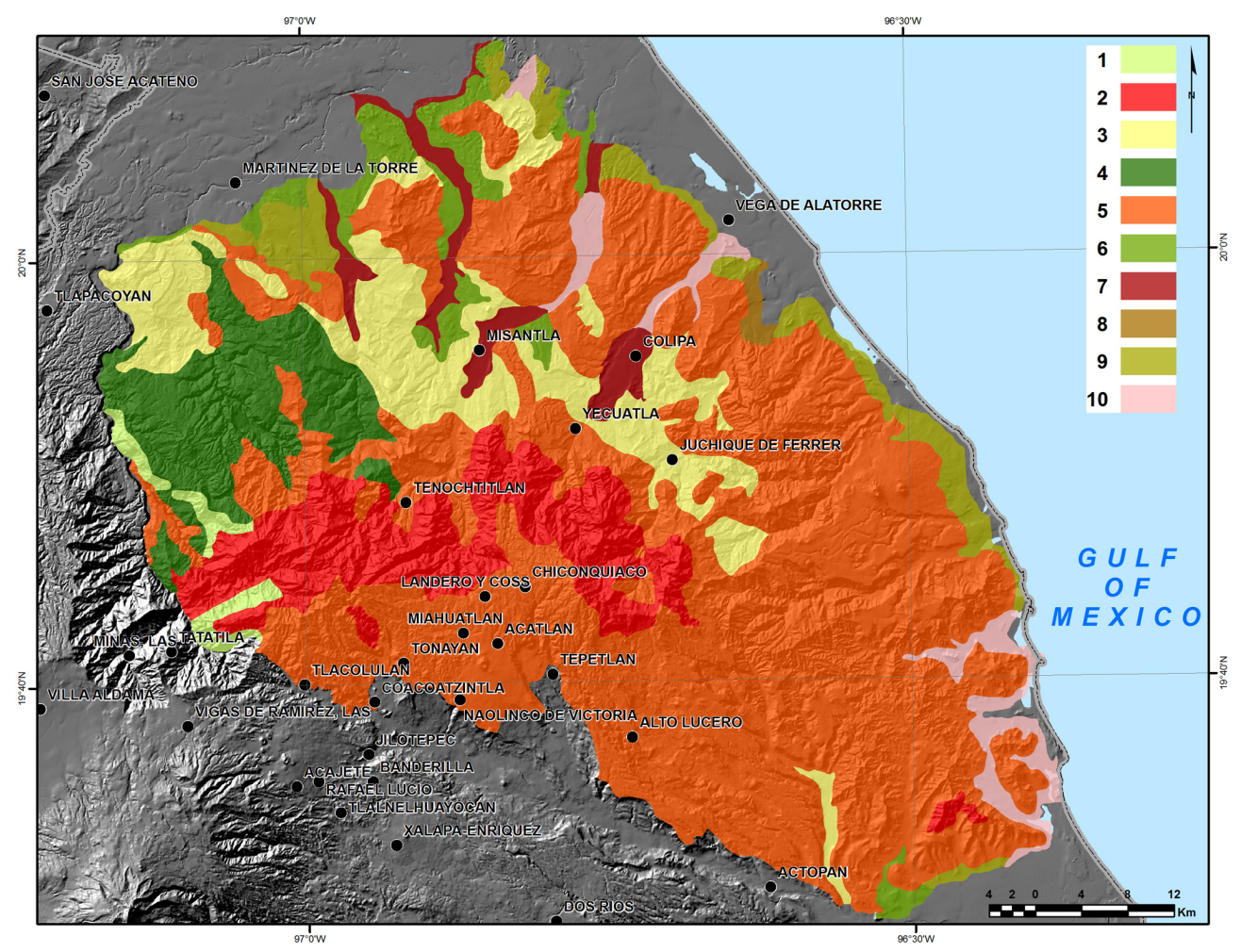

Landforms of moderate $\left(5-20^{\circ}\right)$ and steep slopes $\left(20-45^{\circ}\right)$ occupy most of the Sierra of Chiconquiaco (76\% of the area), overwhelming sedimentary rocks (limestone and sandstone) on the northern mountainside and igneous extrusive rocks on the southern side. The rest of the area is covered by hills and minor elevations, with slopes of less than $20^{\circ}$, over different geological substrates, mainly on the northern side (Figure 3).

The first stage of structural deformation began with the tectonic uplift of the Paleozoic geological basement along a dominant east-west direction (López-Infanzón 1991). This basement was subsequently covered by marine formations that produced the Jurassic and Cretaceous limestone and limestone-lutite, forming the geological structure of the Sierra Madre Oriental. Finally, the products of Cenozoic igneous activity covered the previous formations and, in its central part, a basaltic plateau formed between the Miocene and lower Pliocene (Ferrari et al. 2005). Quaternary lava flows, associated with volcanic monogenetic cones, occurred in the vicinity of Naolinco to the southwest, Chiconquiaco in the center and between Plan de las Hayas and Candelaria to the east, in the direction of Palma Sola.

The summits of the central part of this area constitute the divide of the "Nautla river and others" watershed that belongs to Hydrologic Region 27 (Tuxpan-Nautla) towards the north, and the "Río Jamapa and others" watershed of the Hydrologic Region 28 (Papaloapan) towards the south. Within the Sierra de Chiconquiaco, all of the main rivers (Bobos, Misantla, Colipa, Sedeño, Naolinco) and their tributaries are montane in character and flow quickly through ravines of variable depths.

According to Köppen's system modified by García (1988), the following climatic groups are distinguished from north to south: warm humid with abundant summer rains (type Am(f)) in the northern and northeastern sectors, at elevations below $250 \mathrm{~m}$ a.s.l.; warm humid with rains throughout the year (type $\operatorname{Af}(\mathrm{m})$ ) in a northern strip between 250 and $400 \mathrm{~m}$ a.s.l.; semi-warm with rains throughout the year (type $(\mathrm{A}) \mathrm{C}(\mathrm{fm}))$ up to around $1000 \mathrm{~m}$ a.s.l. in the southwest sector and up to 1,800 m a.s.l. in the central and central-eastern sectors. Above these altitudes, the climate changes to temperate humid with rains throughout the year (type $\mathrm{C}(\mathrm{fm})$ ) or temperate humid with summer rains $(\mathrm{C}(\mathrm{m}))$. Descending the southeast sector, the climate becomes semi-warm with abundant summer rains (type $(\mathrm{A}) \mathrm{C}(\mathrm{m})$ ) and, finally, warm subhumid with summer rains (type $\mathrm{Aw}_{1}(\mathrm{w})$ ) at altitudes below approximately $400 \mathrm{~m}$ a.s.l. towards Actopan and Mozomboa. 
The representative soil types are: a) on the northern mountainside, Luvisols on landforms below approximately 1,000 m a.s.l., over both sedimentary and igneous materials; Andosols on slopes above 1,000 $\mathrm{m}$ a.s.l. (central and western sectors, between Chiconquiaco and Altotonga), exclusively over volcanic ash deposits; Phaeozems on the upper valley fluvial plains and Vertisols on the lower fluvial and coastal plains (from Martínez de la Torre to Vega de Alatorre); b) on the southern mountainside, Andosols extend in the central-western (Altotonga-Las Vigas) and central-southern (Naolinco-Alto Lucero) sectors; Phaeozems in the eastern sector (Plan de las Hayas/Alto Lucero towards the coast) and Vertisols at the bottom of the valleys and on the narrow coastal plains to the south of Emilio Carranza.

Collectors, floristic and vegetation studies. Collections began in 1829 with the German botanists Christian Julius Wilhelm Schiede and Ferdinand Deppe. Franz Leonhard von Schlechtendal and Adelbert von Chamisso subsequently described various species. Schiede and Deppe visited this region in order to search for roots of the Xalapa Jalapa (Ipomoea purga Wender., and wild vanilla (Vanilla spp.). They travelled from Xalapa to El Espinal, Almolonga and Paso del Toro (Malpaís de Naolinco), Naolinco, via Cuesta Grande de Chiconquiaco to Acatlán and to Misantla by Cumbre del Obispo and Papantla. They returned to Xalapa via Hueytamalco, Puebla and Cuesta Grande de Jalacingo and Valle de Perote.

From 1841 to 1843, the Danish botanist Michael Frederick Liebmann conducted intensive collections in Mexico, most of which took place in Veracruz, Puebla and Oaxaca, and produced 8,000 records (Rzedowski et al. 2009). The main interest of this author was ferns and he published a book in 1849 about this group of plants in Mexico. Liebmann left Veracruz in 1841 accompanied by the Russian botanist Wilhelm Friedrich von Karwinski (1780-1855) and both travelled to Papantla, Colipa, Yecuatla, Misantla, Tlapacoyan and Teziutlán. Karwinski separated from Liebmann at El Pital (close to San Rafael) and travelled to Papantla.

In 1905, the German botanist Karl Albert Purpus (1851-1941) established himself in the Hacienda de El Mirador, in the municipality of Totutla (Veracruz state), and travelled from there to different regions of the country to collect plant specimens. On various occasions, he crossed the entire Sierra de Chiconquiaco from Naolinco (Sousa 1969).

Gómez-Pompa (1966) mentioned Ludwig Hahn, George Lewis Fisher and Carl August Ehrenberg, who collected specimens in this Sierra, without recording the exact dates. Between 1950 and 1970, Isabel Kelly and Ladislao Paray also collected specimens. In 1962, the Instituto Nacional de Investigaciones Forestales (INIF), through the Comisión de Estudios Sobre la Ecología de las Dioscóreas, sampled the vegetation of certain areas of the Sierra. Manuel Martínez collected a notable 700 specimens, from 1960 to 1965, and Gómez-Pompa obtained more than 2,000 records, almost always accompanied by Ramón Riba (Gómez-Pompa 1966). From 1970 up to the early 1990s, Francisco Ventura Aburto collected around 1900 specimens for the herbarium of the Escuela Nacional de Ciencias Biológicas. The work of Celso Gutiérrez between 1980 and 1988 is both for the number of specimens collected and the broad range of sites visited, and comprises more than 1,200 records. Roberto Acosta Pérez collected more than 700 specimens in the Sierra Manuel Díaz, located to the southeast of the Sierra de Chiconquiaco, close to the lagoon of La Mancha (Acosta 1986). Miguel Cházaro and his students Luis Robles, Pedro Padilla, Juan Márquez, Apolonia Hernández and Patricia Hernández, collected specimens intermittently from 1981 to the present in locations such as the volcano of Acatlán, Planta del Pié, Barranca de Rincón Grande, Monte de Oro, Cerro de La Magdalena and Las Magdalenitas, Malpaís de Almolonga-Tepetlán, Monte Real, Moxillon, among others, collecting around 500 records. Collectors with more than 100 records in different sites of this Sierra include: Antonio Lot Helgueras, Armando Rincón Gallardo, Carlos Vázquez Yanes, Fructuoso Vázquez Blanco, Mario Vázquez Torres, Gonzalo Castillo Campos, Juan Alba Landa, Javier Chabelas Polito, Jesús Dorantes López, Juan Ismael Calzada, Lorin I. Nevling, Mirna Ambrosio Montoya, Michael Nee, Ma. Teresa Mejía-Saulés and Roberto Ortega Ortiz.

A further result of the different explorations conducted in the Sierra of Chiconquiaco is that 72 species have been recorded with the type locality, 35 of which were early described by D.F. von Schlechtendal and/or F. von Chamisso (Table 1). In recent decades, the studies undertaken became more diverse and featured different approaches. Acosta (1986) produced an inventory 
Table 1. Species with the locality type of the Sierra de Chiconquiaco. Described by D.F von Schlechtendal and/or F. von Chamisso and other authors. DF (Deciduous Forest); THSEF (Tropical High Sub-Evergreen Forest); OF (Oak Forest); TMEF (Tropical Medium Evergreen Forest); TLDF (Tropical Low Deciduous Forest).

Species/Publication year

Bactris mexicana Mart.1844

Bartlettina sordida (Less.) R.M. King \& H. Rob. 19711831

Begonia multistaminea Burt-Utley 1983

B. nelumbonifolia Schldl. \& Cham. 1830

Centradenia grandifolia (Schltdl.) Endl. 1843

C. inaequilateralis G. Don. 1832

Centropogon grandidentatus (Schltdl.) Zahlbr. 1891

Ceratozamia morettii Vázq. Torres \& Vovides 1998

Cestrum endlicheri Miers 1846

Family Vegetation

C. fasciculatum Miers 1846

Apocynaceae

THSEF

Arecaceae

THSEF

Asteraceae

DF

Begoniaceae

DF

Begoniaceae DF

Melastomataceae DF

Melastomataceae DF

Campanulaceae DF

Zamiaceae DF

Solanaceae DF

Solanaceae DF

Chusquea enigmatica Ruiz-Sánchez, Mejía-Saulés \& L. G. Clark. 2014

Clidemia petiolaris Triana. 18721830

Columnea schiedeana Schldl. 1833

Poaceae

Melastomataceae

DF

Gesneriaceae

THSEF

Croton schiedeanus Schltdl. 1846

Cuphea calaminthifolia Schltdl. 1838

Euphorbiaceae

THSEF

Lythraceae

Lythraceae

C. salicifolia Cham. \& Schltdl 1830

Deppea purpusii Standl. 1921

Desmodium plicatum Cham. \& Schltdl. 1830

D. psilophyllum Schltdl. 1838

Desmopsis galeottiana Saff., 1916

Didymaea alsinoides (Schltdl. \& Cham.) Standl. 19381831

Diospyros riojae Gómez-Pompa. 1964

Epidendrum tuxtlense Hágsater, García-Cruz \& L. Sánchez.1999

Equisetum myriochaetum Schldl. \& Cham. 1830

Eugenia mozomboensis P.E. Sánchez. 1986

Eupatorium araliifolium Less. 1831

Euphorbia lancifolia Schldl. 1832

Ficus lapathifolia Miq. 1867

Goeppertia misantlensis(Lascur.) Borchs. \& S. Suárez. 19962012

Rubiaceae

Fabaceae

Fabaceae

Annonaceae

Rubiaceae

Ebenaceae

Orchidaceae

Equisetaceae

Myrtaceae

Asteraceae

Euphorbiaceae

Moraceae

THSEF

DF

DF

DF

DF

OF

TMEF

Gunnera mexicana Brandegee. 1922

Heterocentron elegans Kuntze, 1891

Hydrangea nebulicola Nevling \& Gómez Pompa. 1968

Ipomoea purga Wender. 1833

Leandra cornoides Cogn. 1886

Lepidonia mexicana (Less.) H. Rob. \& V.A. Funk. 19871831

Leucaena pulverulenta Benth. 1842

Licaria misantlae (Brandegee) Kosterm. 1937

Lysiloma auritum (Schltdl.) Benth. 1844

Magnolia schiedeana Schlecht. 1864

Mahonia russellii N.P. Taylor. 1989

Monstera florescanoana Croat, T. Krömer \& Acebey. 2010

Nama linearis D.L. Nash. 1979

Nelsonianthus tapianus (B.L. Turner) C. Jeffrey. 19921989

Odontonema callistachyum Kuntze. 1891

Oecopetalum mexicanum Greenm. \& C.H. Thomps. 1914

Persea schiedeana Nees. 1836

Perymenium gymnolomoides(Less.) DC. 1836

Piper misantlense C. DC. 1869

P. schiedeanum Steud. 1841

Pleopeltis fallax (Schltdl. \& Cham.) Mickel \& Beitel. 18301987

Protium copal (Schltdl. \& Cham.) Engl. 1883

Prunus tetradenia Koehne 1915

Pteris pulchra Schltdl. \& Cham. 1830

Quetzalia schiedeana (Loes.) Lundell. 19701900

Marantaceae

Gunneraceae

Melastomataceae

Hydrangeaceae

Convolvulaceae

Melastomataceae

Asteraceae

Mimosaceae

Lauraceae

Fabaceae

Magnoliaceae

Berberidaceae

Araceae

Boraginaceae

Asteraceae

Acanthaceae

Icacinaceae

Lauraceae

Asteraceae

Piperaceae

Piperaceae

Polypodiaceae

DF

OF

DF

THSEF

TLDF

THSEF

THSEF

THSEF

DF

DF

DF

DF

DF

OF

DF

TLDF

THSEF

THSEF, OF

DF, OF

DF

DF

OF

DF

THSEF

THSEF

THSEF

TMEF, OF

THSEF

TLDF

THSEF

Burseraceae THSEF

Rosaceae

Pteridaceae

THSEF, DF

Celastraceae

THSEF

DF 
Table 1. Continuation.

\begin{tabular}{lll} 
Species/Publication year & Family & Vegetation \\
\hline Rhynchoglossum azureum (Schltdl.) B.L. Burtt 1962 1833 & Gesneriaceae & DF \\
Rhynchosia erythrinoides Schltdl. \& Cham. 1830 & Fabaceae & THSEF \\
Ruellia jussieuoides Schltdl. 1831 & Acanthaceae & THSEF \\
Salvia chazaroana B.L.Turner. 2009 & Lamiaceae & DF \\
Saurauia leucocarpa Schltdl. 1836 & Actinidiaceae & DF \\
Snclairia andromachioides (Less.) Sch. Bip. ex Hemsl. Rydb. 1879-1888 & Asteraceae & THSEF \\
Stenostephanus haematodes (Schltdl.) T.F. Daniel. 1999 1832 & Acanthaceae & DF \\
Tibouchina purpusii Brandegee. 1913 & Melastomataceae & DF \\
T. schiedeana Cogn. 1891 & Melastomataceae & THSEF \\
Tilia mexicana Schltdl. 1837 & Malvaceae & DF \\
Vaccinium leucanthum Schltdl. 1834 1833 & Ericaceae & DF \\
Vernonia arctioides Less. 1831 & Asteraceae & DF \\
Wimmeria concolor Schltdl. \& Cham. 1831 & Celastraceae & TMEF, DF \\
Xylopia trunciflora Cham. \& Schltdl. 1831 & Annonaceae & THSEF \\
Zamia inermis Vovides, J.D. Rees \& Vázq. Torres. 1983 & Zamiaceae & TLDF \\
Zanthoxylum elegantissimum P. Wilson. 1910 & Rutaceae & DF \\
Zygia cognata (Schltdl.) Britton \& Rose. 1928 1838 & Fabaceae & THSEF \\
\hline
\end{tabular}

of the flora of the Sierra Manuel Díaz; Ortega-Ortiz (1981) observed the edge effect on tree densities in fragments of tropical montane cloud forest in Coacoatzintla; Pavón-Hernández (1992) studied the spatial distribution of Tilia mexicana Schltdl. in Naolinco; Bravo-Navarro (1993) conducted an ethnobotanical study in the municipality of Naolinco; Álvarez-Aquino (1997) carried out a population study of Fagus grandifolia subsp. mexicana (Martínez) A.E. Murray in Acatlán; Zamora-Crescencio \& Avendaño-Reyes (1998) studied the vegetation of the municipality of Yecuatla; Ambrosio-Montoya \& Avendaño-Reyes (1999) recorded the useful plants of the municipality of Misantla; Williams-Linera et al. (1996) studied the tropical montane cloud forest across an altitudinal gradient in central Veracruz; Godínez-Ibarra \& López-Mata (2002) recorded the northern limit of distribution of the tropical medium sub-evergreen forest in Santa Gertrudis, in the municipality of Vega de Alatorre; Torres-Cantú (2009) produced an inventory of bromeliads, and Cortés-Flores (2009) of orchids, in the watersheds of the Nautla, Misantla and Colipa rivers; Casildo (2004) produced a floristic inventory in the region Cerro de los Muertos, in the municipality of Altotonga; Gómez-Ortega (2010) contributed to the knowledge of the vegetation and flora of the municipality of Acatlán. Ethnobotanic and management systems of Oecopetalum mexicanum Greenm. \& C.H. Thomps., were studied by Lascurain-Rangel et al. (2013) and López-Acosta et al. (2014). Finally, Carbajal-Hernández et al. (2014) recorded 81 species of ferns in the region.

Vegetation types of the Sierra de Chiconquiaco. Based on the studies of Gómez-Pompa (1966) and Gutiérrez-Báez (1993), and with the aim of standardizing the terminology, the vegetation classification by Miranda \& Hernández X. (1963) was applied. Seven vegetation types were thereby identified (Table 2):

Bosque de pino-encino (Oak-Pine forest).- This type of forest is found on the northern mountainside from 2,100 to 3,000 m a.s.l., comprising communities of Pinus pseudostrobus Lindl., Cupressus lusitanica Mill., Fagus grandifolia subsp. mexicana and Hamamelis virginiana L. (Gutiérrez-Báez 1993). According to observations made by the present authors on the mountains of La Magdalena and Las Magdalenitas (municipalities of Tlacolulan and Tonayan) on the southern mountainside between 2,400 and 2,900 m a.s.l., the Oak-Pine forest is dominated by Pinus patula Schiede \& Deppe ex Schltdl., associated with Quercus glabrescens Benth., $Q$. crassifolia Bonpl. and $Q$. rugosa Née. This vegetation type is located on steep and moderate slopes over extrusive igneous rock.

Bosque caducifolio (Deciduous forest).- This vegetation type covers the majority of the area (Table 2) and is located between 1,100 and 2,100 m a.s.l., from the middle to the summits of 
Table 2. Vegetation types, area and cover percentage on the Sierra de Chiconquiaco. (Source: INEGI 2013 Set of vectorial data of land use and vegetation, scale 1:250,000, Series V. Instituto Nacional de Estadística, Geografía e Informática. México).

\begin{tabular}{lcc} 
Vegetation type & $\mathbf{k m}^{\mathbf{2}}$ & $\begin{array}{c}\text { Percentage } \\
\text { of total }\end{array}$ \\
\hline Oak - pine forest & 22.29 & 0.61 \\
Deciduous forest & 210.62 & 5.80 \\
Sub-evergreen tropical forest; medium sub-evergreen & 73.92 & 2.04 \\
tropical forest & & \\
Tropical low deciduous forest & 71.13 & 1.96 \\
Riparian vegetation & 14.68 & 0.40 \\
Oak forest & 7.86 & 0.22 \\
Secondary vegetation & 534.71 & 14.72 \\
Other vegetation types & 3.70 & 0.10 \\
Pasture & $1,829.09$ & 50.37 \\
Agriculture & 849.53 & 23.39 \\
Bodies of water & 5.75 & 0.16 \\
Urban areas & 8.49 & 0.23 \\
\hline
\end{tabular}

both the northern and southern sides (Gutiérrez-Báez 1993). The dominant arboreal species are: Alchornea latifolia Sw., Alnus acuminata subsp. arguta (Schltdl.) Furlow, Bejaria aestuans Loefl, Capparidastrum quiriguense (Standl.) Cornejo \& Iltis, Clethra mexicana DC., Cupressus lusitanica Mill., Diospyros riojae Gómez-Pompa, Drypetes lateriflora (Sw.) Krug \& Urb., Fagus grandifolia subsp. mexicana, Guarea glabra Vahl, Hamamelis virginiana, Juglans pyriformis Muhl., Liquidambar styraciflua L., Matudaea trinervia Lundell, Osmanthus americanus (L.) Benth. Hook. f. ex A. Gray, Podocarpus matudae Lundell, Quercus affinis M. Martens \& Galeotti, Q. castanea Née, Q. ghiesbreghtii M. Martens \& Galeotti, Q. lancifolia Schltdl. \& Cham., Q. laurina Bonpl., Q. germana Schltdl. \& Cham., Q. polymorpha Schltdl. \& Cham., $Q$. rugosa Née, $Q$. salicifolia Née, $Q$. sartorii Liebm., Q. xalapensis Bonpl., Symplocos coccinea Humb. \& Bonpl., S. limoncillo Bonpl. and Taxus globosa Schltdl. (Gómez-Pompa 1966, Gutiérrez-Báez 1993, Zamora-Crescencio \& Avendaño-Reyes 1998). In one of the highest sites (2,250 m a.s.1.), known locally as Planta del Pié (municipality of Chiconquiaco), WilliamsLinera et al. (1996) identified the most notable arboreal species as: Ageratina ligustrina (DC.) R.M. King \& H. Rob., Alnus acuminata subsp. arguta, Clethra mexicana, Cleyera theaeoides (Sw.) Chosy, Drimys winteri J.R. Forst. \& G. Forst., Ilex discolor var. tolucana (Hemsl.) Edwin ex T.R.Dudley, Osmanthus americanus, Ocotea helicterifolia (Meisn.) Hemsl., Quercus salicifolia, Saurauia leucocarpa Schltdl., Ternstroemia sylvatica Cham. \& Schltdl., Viburnum rhombifolium Hemsl., and Weinmannia pinnata L. Other species described as new are also found: Ardisia liebmannii Oerst., Bactris mexicana Mart., Begonia multinervia Liebm., Goeppertia misantlensis (Lascur.) Borchs. \& S. Suárez, Centradenia grandifolia (Schltdl.) Endl., Chamaedorea pinnatifrons Oerst., Cuphea calaminthifolia Schltdl., Deppea purpusii Standl., Diospyros riojae, Epidendrum tuxtlense Hágsater, García-Cruz \& L. Sánchez, Gunnera mexicana Brandegee, Hydrangea nebulicola Nevling \& Gómez Pompa, Magnolia schiedeana Schlecht., Oecopetalum mexicanum, Persea schiedeana Nees, Prunus tetradenia Koehne, Rumex obtusifolius L., Saurauia leucocarpa, Tibouchina purpusii Brandegee, Tilia mexicana, Vaccinium leucanthum Schltdl. and Vernonanthura patens (Kunth) H. Rob. The deciduous forest is randomly distributed on steep and moderate slopes over extrusive igneous rocks, steep slopes with limestone, moderate slopes upon sandstone and limestone.

Selva alta subperennfolia (Tropical high sub-evergreen forest).- This vegetation type is found the lowlands, between 400 and $850 \mathrm{~m}$ a.s.1., on low hills with low slopes. It was called "tropical Lauraceae forest" by Gómez-Pompa (1966) due to the predominance of species of this family. It is possible to find fragments of this vegetation type in the riparian zones of the streams, with trees of between 20 and $30 \mathrm{~m}$ in height. The physiognomically important species include: Alchornea latifolia, Beilschmiedia anay (S.F. Blake) Kosterm., B. mexicana (Mez) Kosterm., Brosimum alicastrum, Calatola costaricensis Standl., C. mollis Standl., Cymbopetalum pendu- 
liflorum Baill., Dendropanax arboreus (L.) Decne \& Planch., Drypetes lateriflora, Ficus microcarpa L.f., Guarea grandifolia DC., Ocotea sp., Oecopetalum mexicanum, Persea schiedeana, Protium copal (Schltdl. \& Cham.) Engl., Quercus oleoides Schltdl. \& Cham., and Tapirira mexicana Marchand, among others. The tropical high sub-evergreen forest is located on moderate slopes with different geological (extrusive igneous, sandstone and limestone), hills and minor elevations over extrusive igneous rock and on alluvial plains and minor elevation hills over sandstone.

The ecotone of deciduous forest and tropical high sub-evergreen forest, indicated by Gutiérrez-Báez (1993), corresponds to a transition between both vegetation types on wet soils between 850 and 1,100 m a.s.l. The typical species of this association are: Calatola mollis, Coccoloba hirtella Lundell, Drypetes laterifolia, Ficus aurea Nutt, Meliosma alba Walp., Nectandra sp., Oecopetalum mexicanum, Platanus mexicana Moric., Protium copal, Pseudolmedia glabrata, Talauma mexicana G. Don, Tapirira mexicana and Ulmus mexicana Planch.

Selva mediana subperennifolia (Tropical sub-evergreen forest).- Godínez-Ibarra \& López-Mata (2002) reported this vegetation type in Santa Gertrudis (municipality of Vega de Alatorre) at an altitude of between 400 and $651 \mathrm{~m}$ a.s.l. The canopy is greater than $20 \mathrm{~m}$ in height and the following floristic components are representative: Psychotria L. spp., Brosimum alicastrum, Ficus L. spp. Cojoba arborea (L.) Britton \& Rose, Leucaena leucocephala (Lam.) de Wit, Bursera simaruba (L.) Sarg., Trophis racemosa (L.) Urb., Manilkara zapota (L.) P. Royen, Aphananthe monoica (Hemsl.) J.-F. Leroy, Dendropanax arboreus, Cedrela odorata L., Pleuranthodendron lindenii (Turcz.) Sleumer and Nectandra ambigens (S.F. Blake) C.K. Allen. As with the tropical high sub-evergreen forest, the medium sub-evergreen forest is located on moderate slopes with extrusive igneous rocks, sandstone and limestone, on hills and minor elevations over extrusive igneous rock and sandstone, and on alluvial plains.

Selva baja caducifolia (Tropical low deciduous forest, secundary vegetation).- Acosta (1986) described this vegetation type in the Sierra Manuel Díaz (municipality of Actopan) with the following notable floristic components: Tabebuia chrysantha (Jacq.) G. Nicholson, Cochlospermum vitifolium Spreng., Ipomoea wolcottiana Rose, Plumeria rubra L., Bursera simaruba, Ceiba aesculifolia (Kunth) Breitten \& Baker f. and Lysiloma divaricatum (Jacq.) Benth.. This vegetation type covers the slopes of the mountain close to the Gulf of Mexico coast, up to $900 \mathrm{~m}$ a.s.l. Dorantes \& Acosta (1975) also described the tropical low deciduous forest near Farallón (municipality of Actopan) as presenting the following principal woody components: Annona globiflora Schltdl., Bursera simaruba, Caesalpinia cacalaco Bonpl., Cochlospermum vitifolium, Cordia dentata Poir., Diospyros verae-crucis Standl., Ehretia tinifolia L., Enterolobium cyclocarpum (Jacq.) Griseb., Euphorbia schlechtendalii Boiss., Luehea candida Mart., Lysiloma acapulcense (Kunth) Benth., Tabebuia chrysantha and T. rosea DC. This vegetation type is distributed on steep slopes with extrusive igneous rocks, moderate slopes with extrusive igneous rocks and sandstone and on hills and minor elevations with extrusive igneous rock and sandstone.

Encinares (Oak).- This vegetation type is found between 300 and $400 \mathrm{~m}$ a.s.l. and, according to Zamora-Crescencio \& Avendaño-Reyes (1998), on flat areas on the northern mountainside over clay soils. The arboreal stratum does not exceed $10 \mathrm{~m}$ in height and is dominated by Quercus oleoides, accompanied by Piscidia piscipula (L.) Sarg., Dendropanax arboreus, Guazuma ulmifolia Lam., Bursera simaruba, Mimosa albida Humb. \& Bonpl. ex Willd., among other species. According to Gómez-Pompa (1977), the oak forests can be divided into the temperate and warm climatic groups. The temperate oak forests, or those of medium height, are found between 1,000 and 1,300 m a.s.1., in duripan soils (locally called "tepetate") in Mesa de Guadalupe, Alto de Tío Diego, Alto Lucero and Alto del Tizar (Cházaro-Basáñez 1992). This is an arboreal community of 8-15 m in height, of which the notable floristic components are: Quercus peduncularis Née, Q. polymorpha Schltdl. \& Cham., Q. sapotifolia Liebm. and Zinowiew integerrima (Turcz.) Turcz. Ortega-Ortiz (1981) also described an oak forest close to El Espinal (municipality of Naolinco), composed of Quercus polymorpha and Quercus castanea Née. The oak forests of warm regions, or tropical oak forest, are found at an altitude of 10 to $400 \mathrm{~m}$ a.s.l., between Colipa and Vega de Alatorre (Gómez-Pompa 1966), as well as in the vicinity of Laguna Verde-Palma Sola (Gómez-Pompa 1972) and on the heights of Los Atlixcos and Topilitos (municipality of Vega de Alatorre) (Cházaro-Bazañez 1992). The landforms on which it is found correspond to 
Figure 4. Zones with little history of collection. Zone I, Centro del municipio de Alto Lucero; Zone II, Municipio de Actopan; Zone III, Sierra La Bandera; Zone IV, Barrancas de Chiconquiaco-Tepetlán; Zone V, Laderas bajas del norte de la Sierra de Chiconquiaco y Zone VI, Laderas escarpadas.

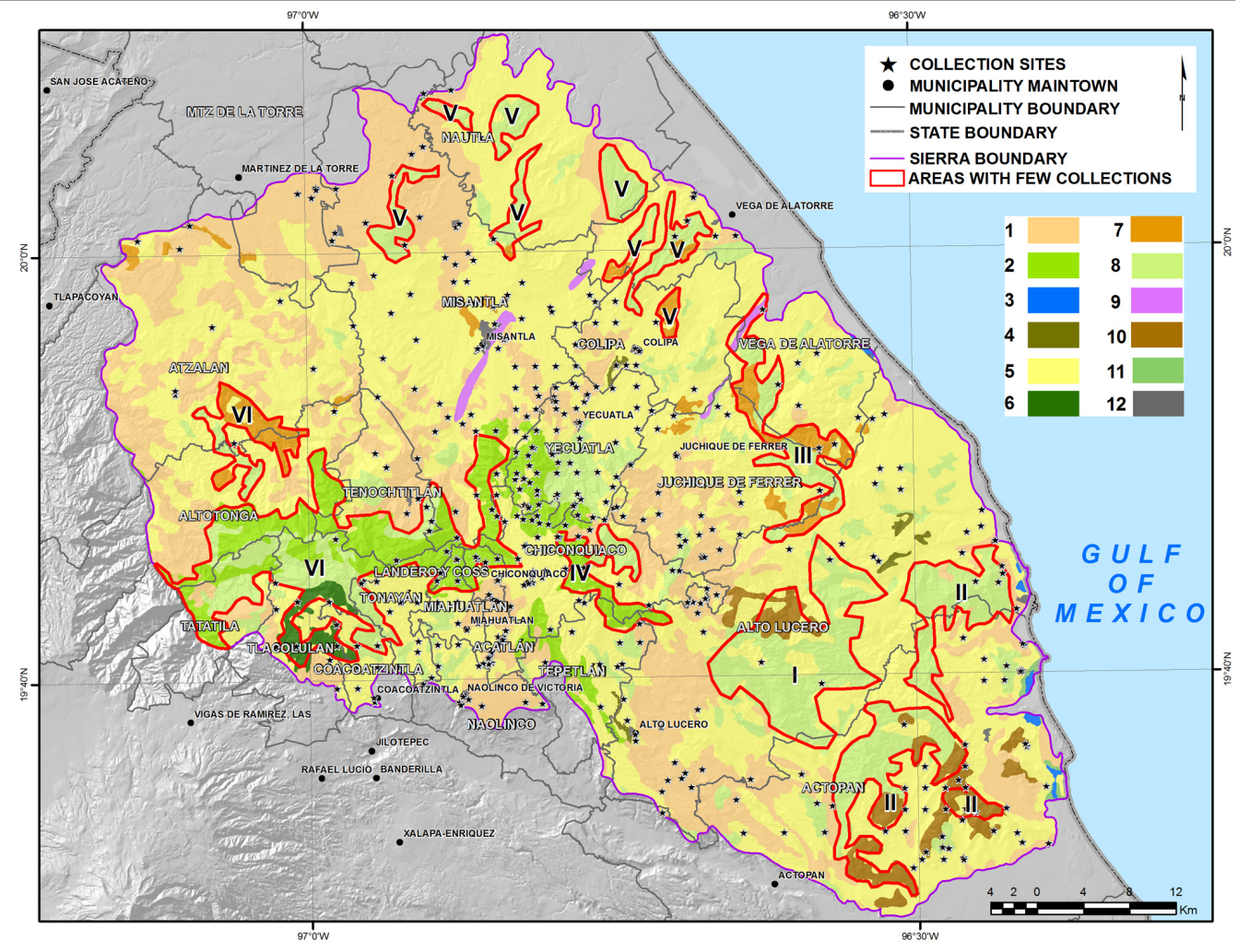

moderate slopes with extrusive igneous rocks, hills and minor elevations over sandstone and on alluvial plains.

Riparia (Riparian).- This vegetation type azonal distribution and is found along permanent or temporary streams, brooks and rivers. Its characteristic species are: Platanus mexicana, Salix humboldtiana Willd., Salix exigua Nutt., Ficus insipida Willd. and Syzigium jambos (L.) Alston, and its accompanying species are: Baccharis salicifolia (Ruiz \& Pav.) Pers. and Pithecellobium lanceolatum Benth. (Zamora-Crescencio \& Avendaño-Reyes 1998). Regarding landforms and geology, riparian vegetation has a ubiquitous distribution and can be found on moderate slopes with extrusive igneous rocks and sandstone, on hills and minor elevations with extrusive igneous rocks, sandstone and conglomerate and on the alluvial plains.

Number of species recorded on the Sierra de Chiconquiaco and rarely explored sites. According to the database of the herbarium XAL and MEXU, there were 3,016 species recorded up to correspond to $35 \%$ of the flora of Veracruz (Villaseñor 2016). The taxa exclusively endemic to the Sierra are: Ceratozamia morettii Vázq. Torres \& Vovides, Chusquea enigmatica Ruiz-Sánchez, Mejía-Saulés \& L. G. Clark, recently described on the volcano of Acatlán (Ruiz-Sánchez et al. 2014), Eugenia mozomboensis P.E. Sánchez, Monstera florescanoana Croat, T. Krömer \& Acebey, Nama linearis D.L. Nash, Piper colipanum C. DC., Salvia chazaroana B.L.Turner, Zamia inermis Vovides, J.D. Rees \& Vázq. Torres. Castilleja eggeri and Echeveria cuquita. The latter two species are currently being described.

The floristic information remains incomplete, since the 4,320 (XAL) specimens collected only cover $30 \%\left(1,061 \mathrm{~km}^{2}\right)$ of the total area. The remaining $70 \%\left(2,570 \mathrm{~km}^{2}\right)$ has undergone little or no collection. The zones with limited history of collection are described below, labelled as zones I to VI and shown in Figure 4.

Zone I, Centro del municipio de Alto Lucero $\left(126 \mathrm{~km}^{2}\right)$.- The zone corresponds to tropical low deciduous forest in Mesa de Tigres and El Tabacal, oak forests located in Las Mesitas, Rancho Nuevo, La Cañada and close to Topiltepec (Arroyo de la Peña and Arroyo de los Cedros), Barranca Hernández and Río de la Barranca to the south of Topilito de Zaragoza. The zone is located on moderate slopes with extrusive igneous rock. 
Figure 5. Potential sites for conservation and priority zones for conservation by $\mathrm{CO}$ NABIO (2004). 1) Centro del municipio de Alto Lucero; 2) Municipio de Actopan; 3) Sierra La Bandera, 4) Barrancas de Chiconquiaco-Tepetlán; 5) Laderas escarpadas en general; 6) Barrancas de Yecuatla; 7) Barranca Diamante; 8) Barranca Chapopote and 9) Laderas al este del cerro Acatlán. I) Pico de Orizaba-Cofre de Perote; II) Dunas costeras del centro de Veracruz and III) Encinares tropicales de la planicie costera Veracruzana.

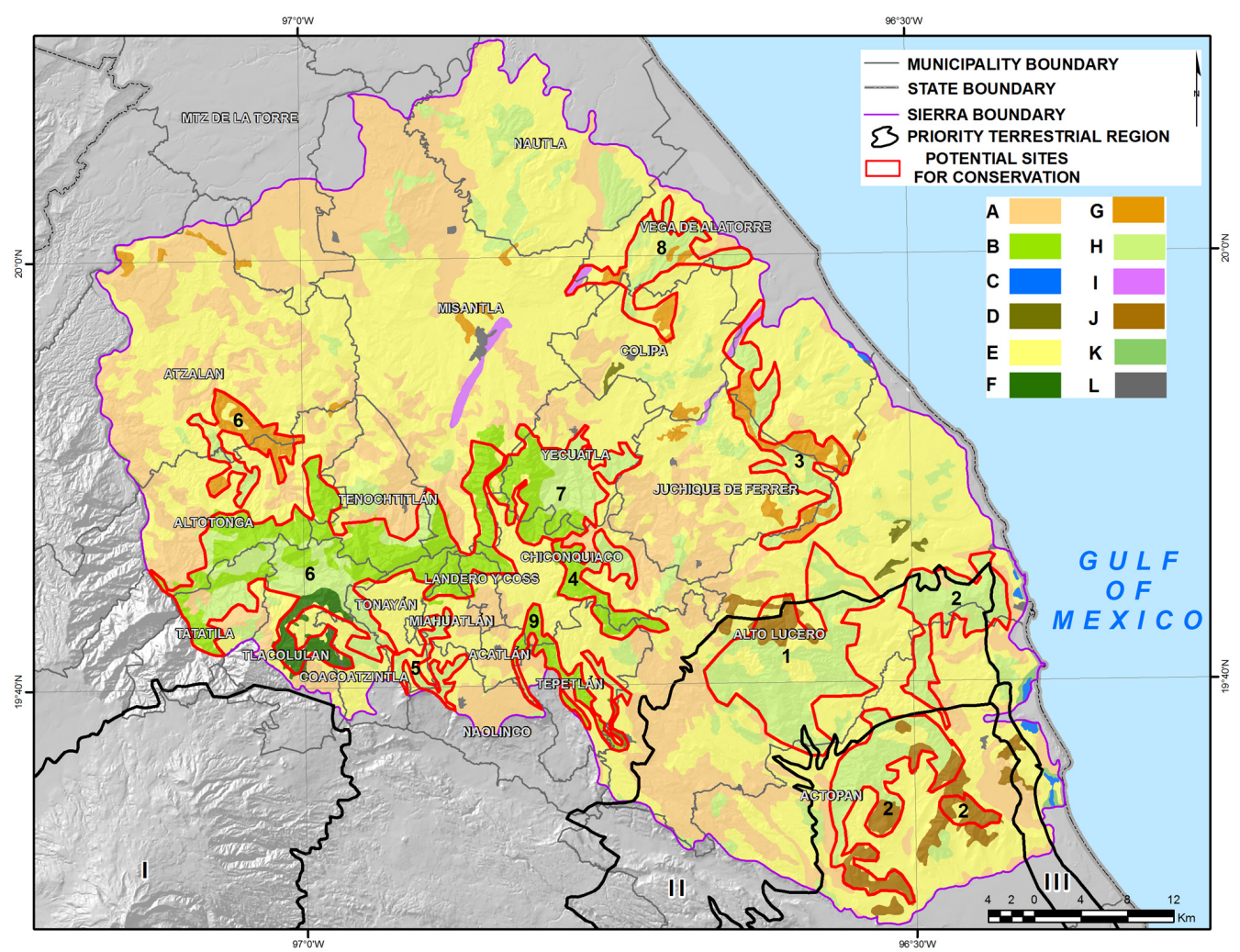

Zone II, Municipio de Actopan $\left(140 \mathrm{~km}^{2}\right)$.- The zone is characterized by tropical low deciduous forest located east of San José Pastorías and San José de la Punta, north of Agua Fría and northeast of Llano de Zárate, Cerro de Tres Picos (Sierra Manuel Díaz) and surroundings. In the vicinity of the mountain La Paila (near Monte de Oro) to the extreme southeast of the municipality of Alto Lucero, towards the coast and between the lagoons of Farallón and Laguna Verde, oak forest communities predominate, while in the northern part of the municipality an area of tropical low deciduous forest extends in the localities of Rancho Italia and Cerro de los Metates in the ravines of the Limón river. The zone is of moderate to steep slopes on extrusive igneous rocks, moderate slopes on sandstone, hills and minor elevations upon extrusive igneous rocks associated with alluvial plains, as well as hills and minor elevations built on sandstone.

Zone III, Sierra La Bandera $\left(63 \mathrm{~km}^{2}\right)$.- The zone corresponds to a tropical medium sub-evergreen forest located in the Sierra La Bandera and to the south of Santa Gertrudis, with the possible presence of secondary vegetation of tropical high evergreen forest. It also includes riparian vegetation along the Juchique river. This zone features moderate slopes with extrusive igneous rocks and sandstone, and hills and minor elevations.

Zone IV, Barrancas de Chiconquiaco-Tepetlán $\left(32 \mathrm{~km}^{2}\right)$.- The zone comprises deciduous and oak forests at Loma Alta, Vista Hermosa, the gullies of El Huérfano, La Sombra, Cerro Totola and Xucuyul (municipality of Chiconquiaco), and in the north of the municipality of Tepetlán in Colonia Cuauhtémoc and the locality of Ocote. The sites of the Rincón Grande canyon, Tepetlán and "malpaís" de San Lorenzo Tepetlán have had little collection. In general, this is a zone of steep and moderate slopes with extrusive igneous rocks.

Zone V, Laderas bajas del norte de la Sierra de Chiconquiaco $\left(94 \mathrm{~km}^{2}\right)$.- The zone extends to the north of the municipality of Misantla, south of Nautla, west of Vega de Alatorre and center of Colipa. The secondary vegetation of tropical high and medium sub-evergreen forest is present in Misantla: El Diamante, the mountains Quebrado and Vista Hermosa; in the municipality of Nautla: the mountains Dos Hermanos and Peña Colorada, El Salto and Pilancones; in Vega de Alatorre: Agua Santa and El Tepe; in Colipa, the mountain El Tigre and El Ocotillo. The zone is characterized by moderate slopes on extrusive igneous rocks and sandstone, hills and minor elevations with extrusive igneous rocks, and sandstone, associated with alluvial plains. 
Zone VI, Laderas escarpadas $\left(260 \mathrm{~km}^{2}\right)$.- It corresponds to the most extensive zone (nine municipalities), where no collection has occurred in the remnants of deciduous forest vegetation. The zone forms a strip that traverses the Sierra of Chiconquiaco from east to west and also includes fragments of secondary tropical high and medium subevergreen forest in the south of the municipality of Atzalan, near the mountains Huizozoco, Naranjal, Plan de la Luz and Martinica, as well as in the northeast of the municipality of Altotonga, on the peaks of Relicario, Cerro de los Muertos and Loma del Arco. Likewise, pine-oak and pine vegetation is found on the La Cebollana-Tlacolulan altitudinal gradient in the municipality of Tlacolulan. Steep and moderate slopes, extrusive igneous rocks and limestone characterize the zone.

Zones of interest for conservation and research. The Serie V (INEGI 2013) regarding land use and vegetation indicates that the overall surface covered by vegetation does not exceed $25 \%$ of the total area. Remnants of vegetation presenting different degrees of disturbance only remain on the abrupt slopes. Among these nine zones with potential for conservation and future research were recognized and labelled as ZCR 1 to 9 (Figure 5). Five of them are the zones with less botanical ZCR 1 (corresponds to Zone I), ZCR 2 (Zone II), ZCR 3 (Zone III), ZCR 4 (Zone

Table 3. Endemic species registered in the Sierra de Chiconquiaco. (Adaptaded from Castillo-Campos et al. 2005).

Species

Alophia veracruzana Goldblatt \& T.M. Howard

Amphitecna tuxtlensis A.H. Gentry

Aristolochia asclepiadifolia Brandegee

Begonia multistaminea Burt-Utley

Begonia pudica L.B. Sm. \& B.G. Schub.

Bomarea gloriosa M. Roem.

Bursera cinerea Engl.

Calyptranthes karwinskyana O. Berg

Calyptranthes schiedeana O. Berg

Calyptranthes schlechtendaliana O. Berg

Ceratozamia morettii Vázq. Torres \& Vovides

Cestrum endlicheri Miers

Chusquea enigmatica Ruiz-Sánchez, Mejía-Saulés \& L. G. Clark

Chusquea mulleri Munro

Costus dirzoi García-Mend. \& Ibarra-Manr.

Cuphea nitidula Kunth

Dioscorea cruzensis R. Knuth

Dioscorea spiculiflora Hemsl. var. fasciculocongesta Sosa \& B.G. Schub.

Eugenia colipensis O. Berg

Eugenia mozomboensis P.E. Sánchez

Eugenia trunciflora (Schltdl. \& Cham.) ex O. Berg

Goeppertia misantlensis (Lascur.) Borchs. \& S. Suárez

Hampea integerrima Schltdl.

Hydrangea nebulicola Nevling \& Gómez Pompa

Maianthemum macrophyllum (M. Martens \& Galeotti) La Frankie

Mammillaria eriacantha Link \& Otto ex Pfeiff.

Mammillaria sartorii J.A. Purpus

Monstera florescanoana Croat, T. Krömer \& Acebey

Nama linearis D.L. Nash

Oncidium stramineum Lindl.

Physalis greenmanii Waterf.

Piper colipanum C. DC.

Salvia chazaroana B.L.Turner

Selaginella pulcherrima Liebm.

Tillandsia tricolor Schltdl. \& Cham.

Zamia inermis Vovides, J.D. Rees \& Vázq. Torres
Family

Iridaceae

Bignoniaceae

Aristolochiaceae

Begoniaceae

Begoniaceae

Alstroemeriaceae

Burseraceae

Myrtaceae

Myrtaceae

Myrtaceae

Zamiaceae

Solanaceae

Poaceae

Poaceae

Costaceae

Lythraceae

Dioscoreaceae

Dioscoreaceae

Myrtaceae

Myrtaceae

Myrtaceae

Marantaceae

Malvaceae

Hydrangeaceae

Convallariaceae

Cactaceae

Cactaceae

Araceae

Boraginaceae

Orchidaceae

Solanaceae

Piperaceae

Lamiaceae

Selaginellaceae

Bromeliaceae

Zamiaceae 
IV), and ZCR 5 (Zone VI). The rest of the zones with interest for conservation a future research are associated with cultivated crops and pastures and correspond to:

ZCR 6. Barrancas de Yecuatla $\left(70 \mathrm{~km}^{2}\right)$, located between the Zones IV and VI with little history of collection, as a strip of deciduous forest to the southwest of Yecuatla, and the localities of Los Brincos towards the south, Chiconquillo to the east and the mountain Pesmón to the west.

ZCR 7. Barranca Diamante $\left(50 \mathrm{~km}^{2}\right)$, located to the southeast of Zone V, with little collection and formed by isolated fragments of tropical high and medium sub-evergreen forest, in the localities of La Planilla to the north, El Naranjal to the south, El Mango towards the east and El Tigre to the west. This zone also includes gallery vegetation along the limits of the municipalities of Vega de Alatorre and Misantla.

ZCR 8. Barranca Chapopote $\left(27 \mathrm{~km}^{2}\right)$, delimited by Rincón Grande to the north, Alto Tío Diego to the south, Las Palomas to the east and Los Cedros to the west, contains sites with deciduous and oak forests that cross the municipality of Tepetlán in a northeast-southeast direction.

ZCR 9. Laderas al este del cerro Acatlán $\left(17 \mathrm{~km}^{2}\right)$, which mostly comprise deciduous forest and diverse fragments of oak forest to the southeast. In other areas of the Sierra of Chiconquiaco, there are numerous disperse fragments of oak forests in the El Tecuán canyon, oak and tropical medium sub-evergreen forests in Los Atlixcos and gallery vegetation to the east of Misantla, along the river of the same name.

According to CONABIO (2004), three of the Veracruz state priority zones for conservation cover the Sierra de Chiconquiaco and correspond to approximately $13 \%$ of its total area (Figure 5): "Pico de Orizaba-Cofre de Perote", comprising a small area $\left(0.03 \mathrm{~km}^{2}\right)$, "Coastal dunes of central Veracruz" with $27 \mathrm{~km}^{2}$ and "Tropical oak forests of the Veracruz coastal plain" which presents the largest area $\left(447 \mathrm{~km}^{2}\right)$.

According to the NOM-059-SEMARNAT (2010), 57 species at risk are recorded in the flora of this Sierra (Appendix 1). They are mainly related to the genus Chamaedorea Willd. and Tillandsia $\mathrm{L}$., with four species each. In that same inventory there are 198 species referenced in CITES (2015), there are registered 36 endemic species from Veracruz (Castillo-Campos et al. 2005), that can be found there. Among them, it is worth mentioning the genus Eugenia L. and Calyptranthes Sw. with three species each one (Table 3).

Oncidium stramineum Lindl., Mammillaria eriacantha Link \& Otto ex Pfeiff. y M. sartorii J.A. Purpus are endemic to Veracruz (Castillo-Campos et al. 2005) and are registered in CITES (2015) appendix II. Tillandsia tricolor Schltdl. \& Cham. and Hydrangea nebulicola Nevling \& Gómez Pompa, are endemic to Veracruz and are also registered in the NOM-059-SEMARNAT (2010); Zamia inermis Vovides, J.D. Rees \& Vázq. Torres, is in appendix II, endemic to Veracruz and in the NOM-059-SEMARNAT (2010).

\section{Conclusion}

Through analysis of geomorphological attributes in a geographic information system, the boundaries of the Sierra of Chiconquiaco were established. Based on a bibliographic review, records of the herbaria, studies and field exploration, seven vegetation types were described, as well as a floristic list of species. Six zones scarcely documented in the herbaria and nine potential areas for conservation and research were detected.

Regarding land use and vegetation of its total area, pastures occupy $50 \%$, agriculture $23 \%$, secondary vegetation $19 \%$, conserved vegetation $7 \%$ and of water and urban zones occupy the remaining $0.7 \%$. This is an indication that there is still $25 \%$ of land covered by vegetation with different degrees of disturbance in the region. The nine zones of interest for conservation (786 $\mathrm{km} 2$ ) together account for only $22 \%$ of the area. Due to the hitherto scarce exploration, these zones could have the potential for the discovery of new species and endemisms. In this Sierra, different types of arboreal vegetation still exist in an altitudinal range between 800 and 2,500 m a.s.l., where deciduous forest occupies the largest area and extends in a strip towards the municipalities of Hueytamalco, Teziutlán, Zongozotla, Zapotitlán de Méndez, Tlaola and Pahuatlán, among others in the state of Puebla.

Floristic importance of the area. The eight exclusively endemic species have rarely been collected and some are of recent description. It is therefore possible to find them in other sites. 
Evaluation of endemism and its distribution and abundance will be crucial in order to formulate and undertake measures for its protection through conservation strategies. This contribution is considered a baseline from which future studies can be conducted in the Sierra of Chiconquiaco related to floristic inventories, quality and estimation of the vegetation cover, land use change, strategies of natural resource management and detection of priority areas for conservation and restoration based on native species and those of traditional use. Floristic and vegetation studies at regional level will continue to be of great importance to the knowledge, use and conservation of biodiversity and to measures for the mitigation of the environmental deterioration of this particular site in Veracruz.

\section{Dedication}

The authors dedicate this contribution to Dr. Arturo Gómez-Pompa for his important studies in the Sierra de Chiconquiaco visionary of the conservation and use of biodiversity of Mexico, and professional guidance.

\section{Acknowledgements}

We thank to Gonzalo Castillo-Campos and Mario Vázquez Torres for their valuable comments on earlier versions of this manuscript. We are grateful to Melissa Covarrubias, Gregoria Zamora, Víctor Luna and Israel Acosta for the support in organizing information the database of plants, and Reyna Paula Zárate for the organization of the manuscript and literature. To Clarissa Ramírez and Gabriela Díaz for mapping the plants collections. This study was supported in part by sabbatical grant to the first author from the Consejo Nacional de Ciencia y Tecnología (Conacyt), Project 233738.

\section{Literature cited}

Acosta PR. 1986. Vegetación de la Sierra de Manuel Díaz, Veracruz. BSc. Thesis, Universidad Veracruzana.

Álvarez-Aquino, C. 1997. Estudio poblacional de Fagus mexicana Martínez en Acatlán, Veracruz, México. MSc. Thesis. Instituto de Ecologia, A.C.

Ambrosio-Montoya M, Avendaño-Reyes S. 1999. Catálogo de plantas útiles del municipio de Misantla, Veracruz. La Ciencia y El Hombre 31: 43-88.

Bojórquez-Tapia LA, Balvanera P, Cuarón AD. 1994. Biological inventories and computer data bases: their role in environmental assessments. Environmental Management 18: 775-785. DOI:10.1007/ BF02394640

Bravo-Navarro F. 1993. Estudio etnobotánico en el Municipio de Naolinco, Veracruz. BSc. Thesis, Universidad Veracruzana.

Casildo A. 2004. Inventario florístico en la región "Cerro de los Muertos” Municipio de Altotongo, Ver. Bs Thesis. Veracruz; Universidad Veracruzana.

Castillo-Campos G, Medina-Abreo ME, Dávila-Aranda PD, Zavala-Hurtado JA. 2005. Contribución al conocimiento del endemismo de la flora vascular en Veracruz, México. Acta Botánica Mexicana 73: 19-57. DOI: $10.21829 / \mathrm{abm} 73.2005 .1004$.

Cházaro-Basáñez M. 1992. Exploraciones botánicas en Veracruz y estados circunvecinos I. Pisos altitudinales de vegetación en el centro de Veracruz y zonas limítrofes de Puebla. La Ciencia y El Hombre 10: 67-116.

CITES. 2015. Convención sobre el Comercio Internacional de Especies Amenazadas de Fauna y Flora Silvestres <cites.org/esp/app/appendices.php> (accessed February 14, 2016).

CONABIO. 2004. Regiones Terrestres Prioritarias. Scale 1:1'000,000. México D.F. <http://www.conabio. gob.mx/informacion/metadata/gis/rtp1mgw.xml?_xsl=/db/metadata/xsl/fgdc_html.xsl\&_indent=no> (accessed October 25, 2016).

Cortés-Flores IS. 2009. Las bromeliáceas en relictos de vegetación de las cuencas de los ríos Nautla, Colipa y Misantla. BSc. Thesis, Universidad Veracruzana.

Dorantes LJ, Acosta M. 1975. Excursión a la zona de Xalapa-Boca Andrea. Guías botánicas de excursiones en México II. Mexico City: Sociedad Botánica de México.

Ellis EA, Martínez-Bello M. 2010. Vegetación y uso de suelo. In Florescano E, Ortiz-Escamilla J. eds. Atlas del Patrimonio Natural, Histórico y Cultural de Veracruz. Comisión del estado de Veracruz para la conmemoración de la Independencia Nacional y la Revolución Mexicana. Universidad Veracruzana. 
Ferrari L, Tagami T, Eguchi M, Orozco-Esquivel T, Pretone CM, Jacobo-Albarrán J, López-Martínez M. 2005. Geology, geochronology and tectonic setting of late Cenozoic volcanism along the southwestern Gulf of Mexico: The Eastern Alkaline Province Revisited. Journal of Volcanology and Geothermal Research 146: 284-306. DOI: org/10.1016/j.jvolgeores.2005.02.004

García E. 1988. Modificaciones al sistema de clasificación climática de Köppen (para adaptarlo a las condiciones de la República Mexicana). Instituto de Geografía, UNAM.

Geissert-Kientz D. 1999. Regionalización geomorfológica del estado de Veracruz. Boletín del Instituto de Geografía UNAM 40: 23-47.

Godínez-Ibarra O, López-Mata L. 2002. Estructura, composición, riqueza y diversidad de árboles en tres muestras de selva mediana subperennifolia. Anales del Instituto de Biología Serie Botánica 73: 283-314.

Gómez-Ortega VA. 2010. Contribución al conocimiento de la Vegetación y Flora del Municipio de Acatlán, Veracruz. BSc. Thesis, Universidad Veracruzana.

Gómez-Pompa A. 1966. Estudios botánicos en la región de Misantla, Veracruz. Mexico, DF: Instituto Mexicano de Recursos Naturales Renovables.

Gómez-Pompa A. 1972. Estudio preliminar de la vegetación y la flora en la región de Laguna Verde, Ver. Informe final del convenio celebrado entre el Instituto de Biología de la UNAM y y el Departamento de Zoología de la Escuela Nacional de Ciencias Biológicas del IPN, dentro del proyecto estudio ecológico de Laguna Verde, Ver. de la Comisión Federal de Electricidad. México DF.

Gómez Pompa A. 1978. Ecología de la vegetación del estado de Veracruz. México: Compañía Editorial Continental.

Gutiérrez Báez, C. 1993. Listado florístico de la sierra de Chiconquiaco, Ver. Textos Universitarios, Universidad Veracruzana.

Gutiérrez-Báez C. 1994. Plantas útiles de Yecuatla, Veracruz. La Ciencia y el Hombre 16: 59-75.

INEGI. 1986. Conjunto de Datos Vectorial Geológico, E1403 y F1412, Escala 1:250,000, Serie I. Aguascalientes, México: Instituto Nacional de Estadística, Geografía e Informática.

INEGI. 1988. Síntesis geográfica, Nomenclator y Anexo Cartográfico del Estado de Veracruz. Aguascalientes, Mexico: Instituto Nacional de Estadística, Geografía e Informática.

INEGI. 1999. Conjunto de Datos Hidrológicos Vectoriales Serie I. Escala 1:250,000. Cartas E1403 y F1412. Mexico: Instituto Nacional de Estadística, Geografía e Informática.

INEGI. 2000. Conjunto de Datos Vectoriales Escala 1:1'000,000. Mexico: Instituto Nacional de Estadística, Geografía e Informática.

INEGI. 2007. Conjunto de Datos Vectoriales Edafológico Serie II. Escala 1:250,000. Mexico: Instituto Nacional de Estadística y Geografía.

INEGI. 2013. Conjunto de datos vectoriales de uso de suelo y vegetación escala 1:250,000, Serie V. Aguascalientes, Mexico: Instituto Nacional de Estadística y Geografía.

INEGI. 2015. Continuo de elevaciones mexicano (CEM) V 3.0. Mexico: Instituto Nacional de Estadística y Geografía. <www.inegi.org.mx/geo/contenidos/datosrelieve/continental/continuoelevaciones.aspx> (accessed May 3, 2016)

Jayakumar S, Kim SS, Heo J. 2011. Floristic inventory and diversity assessment. A critical review. Proceedings of the International Academy of Ecology and Environmental Sciences 1: 151-168.

Lascurain-Rangel M, Avendaño-Reyes S, López-Binnqüist C, López-Acosta JC, Covarrubias-Báez M, Duno-de Stefano R. 2013. Uso y flora leñosa asociada a Oecopetalum mexicanum (Icacinaceae): una especie comestible nativa de la Sierra de Misantla, Veracruz, México. Botanical Sciences 91: 477-484. DOI: $10.17129 /$ botsci.424

López-Acosta JC, Lascurain M, López-Binnqüist C, Covarrubias M. 2014. Structure and floristic composition in local forest management systems of the edible fruit tree Oecopetalum mexicanum in the Sierra de Misantla, Veracruz, Mexico. Economic Botany 68: 44-58. DOI: 10.1007/s12231-014-9260-0

López-Infanzón M. 1991. Petrologic study of volcanic rocks from the Chiconquiaco-Palma Sola area, Central Veracruz, Mexico. MSc. Thesis, New Orleans: Tulane University.

Miranda F, Hernández X. 1963. Los tipos de vegetación de México y su clasificación. Boletín de la Sociedad Botánica de México 28: 29-179.

Morrone JJ. 2005. Hacia una síntesis biogeográfica de México. Revista Mexicana de Biodiversidad 76: 207-252.

Norris WR, Lewis DQ, Widrlechner MP, Thompson JD, Pope RO. 2001. Lessons from an inventory of the Ames, Iowa, flora (1859-2000). Journal-Iowa Academy of Science 108: 34-63.

Ortega-Ortiz R. 1981. Vegetación y flora de una corriente de lava (mal país) al NE del Cofre de Perote, Veracruz. Biótica 6: 57-97.

Pavón-Hernández NP. 1992. Estudio de la distribución espacial de Tilia mexicana Schlecht. en una zona de bosque mesófilo de montaña, en la Sierra de Naolinco, Veracruz. BSc. Thesis, Universidad Veracruzana.

Prance GT. 1977. Floristic inventory of the tropics: where do we stand? Annals of the Missouri Botanical Garden 64: 659-684. DOI: 10.2307/2395293 
Priego Santander AG, Isunza Vera E, Luna González N, Pérez Damián JL. 2003. Anexo I. Disección vertical del relieve de México a escala 1:250 000. In: Priego A, Bocco G, Mendoza M, Garrido A. 2008. Propuesta para la Generación Semi-Automatizada de Unidades de Paisajes: Fundamentos y Métodos. Secretaría del Medio Ambiente y Recursos Naturales, Instituto Nacional de Ecología, Centro de Investigaciones en Geografía Ambiental (UNAM). <http://www.emapas.inecc.gob.mx/download/ paisaje_unidades_paisaje.pdf $>$ (accessed May 25, 2016)

Ruiz-Sánchez E, Mejía-Saules T, Clark LG. 2014. A new endangered species of Chusquea (Poaceae: Bambusoideae) from the Acatlan volcano in central Veracruz, Mexico, and keys to the Mexican Chusquea species. Phytotaxa 163: 16-26. DOI: http://dx.doi.org/10.11646/phytotaxa.163.1.2

Rzedowski J. 1978. Vegetación de México. Mexico DF: Limusa.

Rzedowski J, Calderón-de Rzedowski G, Butanda A. 2009. Los principales colectores de plantas activos en México entre 1700 y 1930. Patzcuaro, Michoacan: Instituto de Ecología, A.C.-CONABIO.

SEMARNAT 2010. Norma Oficial Mexicana NOM-059-SEMARNAT-2010, Protección ambiental-Especies nativas de México de flora y fauna silvestres-Categorías de riesgo y especificaciones para su inclusión, exclusión o cambio-Lista de especies en riesgo. Diario Oficial de la Federación (Segunda Sección). Mexico, DF: Secretaría de Medio Ambiente y Recursos Naturales.

Sousa M. 1969. Las colecciones botánicas de C.A. Purpus en México. University of California Publications in Botany 51: 1-36.

Torres-Cantú GB. 2009. Orquídeas (epidendroideae y vandoideae) presentes en los remanentes de vegetación original de la zona propuesta como reserva de la Biosfera de las Cuencas de los Ríos Nautla, Colipa y Misantla. BSc. Thesis, Universidad Veracruzana.

Villaseñor JL. 2003. Diversidad y distribución de las Magnoliophyta de México. Interciencia 28: 160167.

Villaseñor JL. 2016. Checklist of the native vascular plants of México. Revista Mexicana de Biodiversidad 87: $559-902$.

Williams-Linera G, Pérez GY, Tolome J. 1996. El Bosque Mesófilo de Montaña y un Gradiente Altitudinal en el Centro de Veracruz, México. La Ciencia y el Hombre 8: 149-161.

Zamora-Crescencio P, Avendaño-Reyes S. 1998. La vegetación del Municipio de Yecuatla, Veracruz, México. La Ciencia y el Hombre 28: 27-65. 
Appendix 1.

\begin{tabular}{|c|c|c|c|c|c|}
\hline SCIENTIFIC NAME & CITES & NOM- 059 & SCIENTIFIC NAME & CITES & NOM- 059 \\
\hline ACANTHACEAE & & & Saurauia leucocarpa Schltdl. & & \\
\hline Aphelandra schiedeana Cham. \& Schltdl. & & & Saurauia pedunculata Hook. & & \\
\hline Barleria discolor Nees & & & Saurauia scabrida Hemsl. & & \\
\hline Barleria oenotheroides Dum. Cours. & & & Saurauia villosa DC. & & \\
\hline Blechum brownei Juss. & & & ADOXACEAE & & \\
\hline Blechum pyramidatum (Lam.) Urb. & & & Sambucus canadensis L. & & \\
\hline Chileranthemum trifidum Oerst. & & & Viburnum caudatum Greenm. & & \\
\hline Dicliptera acuminata Juss. & & & Viburnum ciliatum Greenm. & & \\
\hline Dicliptera unguiculata Nees & & & Viburnum microcarpum Schltdl. \& Cham. & & \\
\hline Dyschoriste decumbens (A. Gray) Kuntze & & & Viburnum rhombifolium Hemsl. & & \\
\hline Dyschoriste quadrangularis (Oerst.) Kuntze & & & Viburnum tiliifolium Hemsl. & & \\
\hline Eytraria bromoides Oerst. & & & AIZOACEAE & & \\
\hline 日ytraria imbricata (Vahl) Pers. & & & Trianthema portulacastrum L. & & \\
\hline Glockeria gracilis Nees & & & ALISMATACEAE & & \\
\hline Hansteinia gracilis Oerst. & & & Echinodorus andrieuxii (Hook. \& Arn.) & & \\
\hline Henrya insularis Nees & & & Small & & \\
\hline Hypoestes lasiostegia var. sanguinolenta & & & ALLIACEAE & & \\
\hline (Van Houtte) Benoist & & & Nothoscordum bivalve (L.) Britton & & \\
\hline Hypoestes phyllostachya Baker & & & ALSTROEMERIACEAE & & \\
\hline acobinia paniculata Oerst. & & & Bomarea acutifolia Herb. & & \\
\hline Msticia fulvicoma Cham. \& Schltdl. & & & Bomarea edulis Herb. & & \\
\hline Msticia aurea Schltdl. & & & Bomarea gloriosa M. Roem. & & \\
\hline Msticia borrerae Hemsl. & & & ALTINGIACEAE & & \\
\hline Usticia breviflora Rusby & & & Liquidambar styraciflua Oerst. & & \\
\hline Msticia campechiana Standl. & & & AMARANTHACEAE & & \\
\hline Msticia candelariae (Oerst.) Leonard & & & Achyranthes aspera L. & & \\
\hline Msticia comata (L.) Lam. & & & Alternanthera flavescens Kunth & & \\
\hline Msticia macrantha Benth. & & & Alternanthera gracilis Loes. & & \\
\hline Msticia pectoralis Jacq. & & & Alternanthera Ianceolata Schinz & & \\
\hline Msticia sessilis Jacq. & & & Amaranthus scariosus Benth. & & \\
\hline Msticia spicigera Schltdl. & & & Amaranthus spinosus L. & & \\
\hline Odontonema callistachyum Kuntze & & & Blutaparon vermiculare (L.) Mears & & \\
\hline Pseuderanthemum praecox (Benth.) & & & Celosia argentea L. & & \\
\hline Leonard & & & Celosia nitida Vahl & & \\
\hline Pseuderanthemum standleyi Leonard & & & Chamissoa altissima Kunth & & \\
\hline in Standl. & & & Chenopodium ambrosioides $\mathrm{L}$. & & \\
\hline Ruellia coerulea Morong & & & Chenopodium graveolens Willd. & & \\
\hline Ruellia erythropus Lindau & & & Chenopodium murale L. & & \\
\hline Ruellia inundata Kunth & & & Cyathula achyranthoides Moq. & & \\
\hline Ruellia jussieuoides Standl. & & & Froelichia floridana (Nutt.) Moq. & & \\
\hline Ruellia spissa Leonard & & & Gomphrena nana Standl. & & \\
\hline Siphonoglossa canbyi (Greenm.) & & & Gomphrena pilosa Moq. & & \\
\hline Hilsenb. & & & Gomphrena serrata L. & & \\
\hline Spathacanthus hahnianus Baill. & & & Hebanthe grandiflora (Hook.) Borsch & & \\
\hline Spathacanthus parviflorus Leonard & & & \& Pedersen & & \\
\hline Stenandrium dulce Nees & & & Iresine arbuscula Uline \& W.L. Bray & & \\
\hline Stenostephanus haematodes (Schltdl.) & & & Iresine diffusa Humb. \& Bonpl. ex Willd. & & \\
\hline T.F. Daniel & & & Iresine hebanthoides Suess. & & \\
\hline Tetramerium nervosum Nees & & & Iresine herbstii Hook. & & \\
\hline Tetramerium scorpioides (L.) Hemsl. & & & Iresine herrerae Conz. \& S.F. Blake & & \\
\hline Thunbergia alata Bojer ex Sims & & & Iresine interrupta Benth. & & \\
\hline Thunbergia convolvulifolia Baker & & & Iresine Iatifolia Moq. & & \\
\hline Thunbergia grandiflora Roxb. & & & Iresine nigra Uline \& W.L. Bray & & \\
\hline ACERACEAE & & & Pleuropetalum sprucei Standl. & & \\
\hline Acer negundo L. & & & AMARYLLIDACEAE & & \\
\hline ACTINIDIACEAE & & & Allium glandulosum Link \& Otto & & \\
\hline Saurauia cana B.T. Keller \& Breedlove & & & Crinum americanum L. & & \\
\hline
\end{tabular}


Appendix 1. Continuation.

\begin{tabular}{|c|c|c|c|c|c|}
\hline SCIENTIFIC NAME & CITES & NOM- 059 & SCIENTIFIC NAME & CITES & NOM- 059 \\
\hline Crinum x powellii hort. ex Baker & & & APOCYNACEAE & & \\
\hline Manfreda scabra (Ortega) McVaugh & & & Allamanda cathartica L. & & \\
\hline Zephyranthes carinata Herb. & & & Alstonia longifolia (A. DC.) Pichon & & \\
\hline ANACARDIACEAE & & & Apocynum cannabinum L. & & \\
\hline Astronium graveolens Jacq. & & $\diamond$ & Asclepias curassavica L. & & \\
\hline Comocladia engleriana Loes. & & & Asclepias similis Hemsl. & & \\
\hline Pistacia mexicana Kunth & & & Asclepias woodsoniana Standl. & & \\
\hline Rhus terebinthifolia Schltdl. \& Cham. & & & \& Steyerm. & & \\
\hline Spondias mombin L. & & & Aspidosperma megalocarpon & & \\
\hline Tapirira mexicana Marchand & & & Müll. Arg. & & \\
\hline Toxicodendron radicans (L.) Kuntze & & & Blepharodon mucronatum (Schltdl.) & & \\
\hline ANEMIACEAE & & & Decne. & & \\
\hline Anemia phyllitidis (L.) Sw. & & & Catharanthus roseus (L.) G. Don & & \\
\hline Anemia tomentosa (Sav.) Sw. & & & Cryptostegia grandiflora R. Br. & & \\
\hline ANNONACEAE & & & Cynanchum mexicanum Brandegee & & \\
\hline Annona cherimola Miller & & & Echites microcalyx A. DC. & & \\
\hline Annona globiflora Schltdl. & & & Fernaldia pandurata (A. DC.) & & \\
\hline Annona longiflora S. Watson & & & Woodson & & \\
\hline Annona muricata L. & & & Forsteronia myriantha Donn. Sm. & & \\
\hline Annona purpurea Moc. \& Sessé ex Dunal & & & Forsteronia spicata G. Mey. & & \\
\hline Cymbopetalum baillonii R.E. Fr. & & & Funastrum clausum Schltr. & & \\
\hline Cymbopetalum penduliflorum Baill. & & & Gomphocarpus physocarpus E. Mey. & & \\
\hline Desmopsis galeottiana Saff. & & & Gonolobus chloranthus Schltdl. & & \\
\hline Desmopsis trunciflora (Schltdl. \& Cham.) & & & Gonolobus erianthus Decne. & & \\
\hline G.E. Schatz & & & Gonolobus niger (Cav.) R. Br. & & \\
\hline Guatteria amplifolia Triana \& Planch. & & & ex Schult. & & \\
\hline Mosannona depressa (Baill.) Chatrou & & & Gonolobus uniflorus Kunth & & \\
\hline Rollinia mucosa (Jacq.) Baill. & & & Mandevilla acutiloba (A. DC.) & & \\
\hline Tridimeris hahniana Baill. & & & Woodson & & \\
\hline Xylopia trunciflora Schltdl. \& Cham. & & & Mandevilla subsagittata (Ruiz \& & & \\
\hline APIACEAE & & & Pav.) Woodson & & \\
\hline Ammi majus L. & & & Mandevilla torosa (Jacq.) Woodson & & \\
\hline Angelica nelsonii J.M. Coult. \& Rose & & & Marsdenia macrophylla E. Fourn. & & \\
\hline Apium leptophyllum (Pers.) F. Muell. & & & Matelea nigrescens (Schltdl.) Woodson & & \\
\hline ex Benth. & & & Matelea sugillata W.D. Stevens & & \\
\hline Arracacia aegopodioides J.M. Coult. & & & Matelea velutina (Schltdl.) Woodson & & \\
\hline \& Rose & & & Mesechites trifidus Müll. Arg. & & \\
\hline Arracacia nelsonii J.M. Coult. \& Rose & & & Metastelma barbigerum Scheele & & \\
\hline Arracacia rigida J.M. Coult. \& Rose & & & Metastelma latifolium Rose & & \\
\hline Berula erecta (Huds.) Coville & & & Metastelma pringlei A. Gray & & \\
\hline Cicuta maculata var. maculata L. & & & Metastelma schlechtendalii Decne. & & \\
\hline Coriandrum sativum L. & & & Oxypetalum cordifolium (Vent.) Schltr. & & \\
\hline Cyclospermum leptophyllum (Pers.) & & & Pentalinon andrieuxii (Müll. Arg.) & & \\
\hline Sprague ex Britton \& P. Wilson & & & B.F. Hansen \& Wunderlin & & \\
\hline Daucus montanus Humb. \& Bonpl. & & & Plumeria rubra L. & & \\
\hline ex Spreng. & & & Polystemma viridiflorum Decne. & & \\
\hline Eryngium carlinae F. Delaroche & & & Prosthecidiscus guatemalensis Donn. Sm. & & \\
\hline Eryngium deppeanum Schltdl. \& Cham. & & & Rauvolfia tetraphylla L. & & \\
\hline Eryngium foetidum $\mathrm{L}$. & & & Rhabdadenia biflora Müll. Arg. & & \\
\hline Eryngium nasturtiifolium Juss. ex F. & & & Sarcostemma clausum Schult. & & \\
\hline Delaroche & & & Sarcostemma elegans Decne. & & \\
\hline Foeniculum vulgare Hill & & & Sarcostemma pannosum Decne. & & \\
\hline Micropleura renifolia Lag. & & & Stemmadenia donnell-smithii (Rose) & & \\
\hline Prionosciadium thapsoides (DC.) Mathias & & & Woodson & & \\
\hline Sanicula liberta Cham. \& Schltdl. & & & Stemmadenia litoralis (Kunth) L. Allorge & & \\
\hline Spananthe paniculata Jacq. & & & Tabernaemontana alba Mill. & & \\
\hline Tauschia nudicaulis Schltdl. & & & Thevetia ahouai (L.) A. DC. & & \\
\hline
\end{tabular}


Appendix 1. Continuation.

$\frac{\text { SCIENTIFIC NAME }}{\text { Thevetia peruviana K. Schum. }}$

Tintinnabularia gratissima J.F. Morales

Tonduzia longifolia (DC.) Markgr.

Trachelospermum difforme (Walter)

$$
\text { A. Gray }
$$

Vinca major L.

AQUIFOLIACEAE

Ilex discolor Hemsl. var. tolucana

(Hemsl.) Edwin ex T.R. Dudley

Ilex pringlei Standl.

ARACEAE

Alocasia macrorrhizos (L.) G. Don

Anthurium andicola Liebm.

Anthurium crassinervium (Jacq.) Schott

Anthurium harrisii G. Don

Anthurium pentaphyllum G. Don

Anthurium podophyllum Kunth

Anthurium scandens (Aubl.) Engl.

Anthurium schlechtendalii Kunth

Anthurium umbrosum Liebm.

Arisaema dracontium (L.) Schott

Arisaema macrospathum Benth.

Dieffenbachia oerstedii Schott

Monstera acuminata K. Koch

Monstera florescanoana Croat, T.

Kromer \& Acebey

Monstera lechleriana Schott

Philodendron advena Schott

Philodendron guttiferum Kunth

Philodendron inaequilaterum subsp.

Inaequilaterum Liebm.

Philodendron jacquinii Schott

Philodendron radiatum Schott

Philodendron sagittifolium Liebm.

Philodendron seguine subsp.

lingua-bovis Grayum

Syngonium neglectum Schott

Syngonium podophyllum Schott

Xanthosoma mexicanum Liebm.

Xanthosoma robustum Schott

Zantedeschia aethiopica Spreng.

ARALIACEAE

Dendropanax arboreus (L.) Decne

\& Planch.

Hydrocotyle mexicana Cham. \& Schltdl.

Hydrocotyle umbellata L.

Hydrocotyle verticillata Thunb.

Oreopanax capitatus (Jacq.) Decne.

$\&$ Planch.

Oreopanax echinops Decne. \& Planch.

Oreopanax flaccidus Marchal

Oreopanax liebmannii Marchal

Oreopanax peltatus Linden

Oreopanax xalapensis Decne. \& Planch.

ARECACEAE

Acrocomia aculeata Lodd. ex Mart.

Bactris mexicana Mart.
CITES NOM- 059 SCIENTIFIC NAME

CITES NOM- 059

Bactris trichophylla Burret

Chamaedorea concolor Mart.

Chamaedorea elatior Mart.

Chamaedorea elegans Mart.

Chamaedorea klotzschiana $\mathrm{H}$. Wendl.

Chamaedorea monostachys Burret

Chamaedorea oblongata Mart.

Chamaedorea oreophila Mart.

Chamaedorea pinnatifrons Oerst.

Chamaedorea sartorii Liebm.

Sabal mexicana Mart.

ARISTOLOCHIACEAE

Aristolochia asclepiadifolia Brandegee

Aristolochia pentandra Jacq.

ASPARAGACEAE

Agave angustifolia Haw.

$\checkmark \quad$ Agave applanata Koch

Agave filifera Salm-Dyck

Agave obscura Schiede

Agave pendula Schnittsp.

Agave polyacantha Haw.

Agave univittata Haw.

Agave xalapensis Roezl ex Jacobi

Beaucarnea recurvata Lem.

Beschorneria calcicola García-Mend.

Beschorneria yuccoides subsp.

dekosteriana (K. Koch) García-Mend.

Cordyline fruticosa (L.) A. Chev.

Echeandia longipedicellata Cruden

Echeandia parviflora Baker

Maianthemum macrophyllum (M.

Martens \& Galeotti) La Frankie

Maianthemum paniculatum (M. Martens

\& Galeotti) La Frankie

Maianthemum scilloideum (M. Martens

\& Galeotti) LaFrankie

Nolina humilis S. Watson

Yucca guatemalensis Baker

ASPLENIACEAE

Asplenium achilleifolium (M. Martens

\& Galeotti) Liebm.

Asplenium alatum Humb. \& Bonpl.

ex Willd.

Asplenium auriculatum Sw.

Asplenium auritum Sw.

Asplenium blepharodes D.C. Eaton

Asplenium cristatum Lam.

Asplenium cuspidatum Lam.

Asplenium formosum Willd.

Asplenium hastatum Klotzsch ex Kunze

Asplenium miradorense Liebm.

Asplenium monanthes L.

Asplenium pumilum Sw.

Asplenium repandulum Kunze

Asplenium resiliens Kunze

Asplenium salicifolium L.

Asplenium scolopendrium L. 
Appendix 1. Continuation.

\section{SCIENTIFIC NAME}

Asplenium serra Langsd. \& Fisch.

Asplenium sessilifolium Desv.

Asplenium sphaerosporum A.R. Sm.

ASTERACEAE

Achillea lanulosa Nutt.

Achillea millefolium L.

Acmella oppositifolia (Lam.) R.K. Jansen

Acourtia veracruzana B.L. Turner

Ageratina aschenborniana (S. Schauer)

R.M. King \& H. Rob.

Ageratina bellidifolia (Benth.) R.M.

King \& H. Rob.

Ageratina chiapensis (B.L. Rob.) R.M.

King \& H. Rob.

Ageratina choricephala (B.L. Rob.)

R.M. King \& H. Rob.

Ageratina crassiramea (B.L. Rob.)

R.M. King \& H. Rob.

Ageratina enixa (B.L. Rob.) R.M.

King \& $\mathrm{H}$. Rob.

Ageratina havanensis (Kunth) R.M.

King \& H. Rob.

Ageratina ligustrina (DC.) R.M.

King \& $\mathrm{H}$. Rob.

Ageratina mairetiana (DC.) R.M.

King \& H. Rob.

Ageratina petiolaris (Moc. \& Sessé

ex DC.) R.M. King \& H. Rob.

Ageratina pichichensis (Kunth)

R.M. King \& H. Rob.

Ageratina vernalis (Vatke \& Kurtz)

R.M. King \& Rob.

Ageratina wrightii (A. Gray) R.M.

King \& $\mathrm{H}$. Rob

Ageratum conyzoides L.

Ageratum corymbosum Zuccagni

Ageratum houstonianum Mill.

Aldama dentata La Llave

Alloispermum integrifolium (DC.)

H. Rob.

Alloispermum scabrum (Lag.) H. Rob.

Alomia echioides(Less.) B.L. Rob.

Ambrosia peruviana All.

Archibaccharis asperifolia S.F. Blake

Archibaccharis hirtella (DC.) Heering

Archibaccharis intermedia (S.F. Blake)

B.L. Turner

Archibaccharis schiedeana (Benth.)

J.D. Jacks.

Archibaccharis serratifolia S.F. Blake

Archibaccharis sescenticeps (S.F.

Blake) S.F. Blake

Artemisia Iudoviciana Nutt.

Artemisia mexicana Willd. ex Spreng.

Aster exilis Elliott

Aster schaffneri Sch. Bip. ex S.D. Sundb.

\& A.G. Jones

CITES NOM- 059 SCIENTIFIC NAME

CITES NOM- 059

Aster subulatus Michx.

Astranthium xanthocomoides (Less.)

Larsen

Baccharis conferta Kunth

Baccharis rhexioides Kunth

Baccharis salicifolia (Ruiz \& Pav.)

Pers.

Baccharis serratifolia Kunth

Baccharis serrifolia DC.

Baccharis thesioides Kunth

Baccharis trinervis Pers.

Baltimora geminata (Brandegee)

Stuessy

Barkleyanthus salicifolius (Kunth)

H. Rob. \& Brettell

Bartlettina karwinskiana (DC.)

R.M. King \& H. Rob.

Bartlettina oresbia (B.L. Rob.)

R.M. King \& H. Rob.

Bartlettina sordida (Less.) R.M.

King \& H. Rob.

Bartlettina tuerckheimii (Klatt)

R.M. King \& H. Rob.

Bartlettina xalapana (B.L. Turner)

B.L. Turner

Bidens aurea (Aiton) Sherff

Bidens triplinervia Kunth

Brickellia diffusa (Vahl) A. Gray

Brickellia pacayensis J.M. Coult.

Brickellia paniculata (Mill.) B.L.

Rob.

Calea ternifolia Kunth

Calea urticifolia DC.

Calendula officinalis L.

Calyptocarpus vialis Less.

Chaptalia nutans (L.) Pol.

Chromolaena odorata (L.) R.M.

King \& H. Rob.

Chrysanthemum parthenium Bernh.

Cirsium conspicuum Sch. Bip.

Cirsium lappoides Sch. Bip.

Cirsium mexicanum DC.

Cirsium pinetorum Greenm.

Clibadium surinamense $\mathrm{L}$.

Conyza bonariensis (L) Cronquist

Conyza canadensis (L.) Cronquist

Conyza coronopifolia Kunth

Conyza laevigata (Rich.) Pruski

Critonia dal eoides DC.

Critonia hospitalis (B.L. Rob.) R.M.

King \& H. Rob.

Critonia morifolia (Mill.) R.M.

King \& H. Rob.

Critoniadelphus nubigenus (Benth.)

R.M. King \& H. Rob.

Critoniopsis triflosculosa (Kunth)

Rob 
Appendix 1. Continuation.

\begin{tabular}{|c|c|c|c|c|c|}
\hline SCIENTIFIC NAME & CITES & NOM- 059 & SCIENTIFIC NAME & CITES & NOM- 059 \\
\hline Dahlia coccinea Cav. & & & Koanophyllon solidaginoides & & \\
\hline Decachaeta perornata (Klatt) R.M. & & & (Kunth) R.M. King \& H. Rob. & & \\
\hline King \& H. Rob. & & & Lactuca graminifolia Michx. & & \\
\hline Delilia berteroi Spreng. & & & Lactuca ludoviciana (Nutt.) & & \\
\hline Dyssodia aurantia (L.) B.L. Rob. & & & Riddell & & \\
\hline Dyssodia porophyllum (Cav.) Cav. & & & Laennecia schiedeana (Less.) & & \\
\hline Dyssodia tagetiflora Lag. & & & G.L. Nesom & & \\
\hline Eclipta prostrata (L.) L. & & & Lagascea helianthifolia Kunth & & \\
\hline Egletes liebmannii Sch. Bip. & & & Lagascea mollis Cav. & & \\
\hline Bephantopus mollis Kunth & & & Lapsana communis L. & & \\
\hline Epaltes mexicana Less. & & & Launaea intybacea Beauverd & & \\
\hline Erechtites hieracifolia Raf. & & & Leiboldia serrata Gleason & & \\
\hline Erechtites valerianifolia Less & & & Lepidaploa salzmannii (DC.) & & \\
\hline Erigeron karvinskianus DC. & & & H. Rob. & & \\
\hline Erigeron longipes DC. & & & Lepidaploa tortuosa (L.) H. Rob. & & \\
\hline $\begin{array}{l}\text { Erigeron procumbens (Houst. ex } \\
\text { Mill.) G.L. Nesom }\end{array}$ & & & $\begin{array}{l}\text { Lepidonia mexicana (Less.) H. } \\
\text { Rob. \& V.A. Funk. }\end{array}$ & & \\
\hline Erigeron scaberrimus Gardner & & & Leucanthemum vulgare Lam & & \\
\hline Erigeron veracruzensis G.L. Nesom & & & Liabum bourgeaui Hieron. & & \\
\hline $\begin{array}{l}\text { Eupatorium albicaule Sch. Bip. } \\
\text { ex Klatt }\end{array}$ & & & $\begin{array}{l}\text { Loxothysanus sinuatus (Less.) } \\
\text { B.L. Rob. }\end{array}$ & & \\
\hline Eupatorium araliifolium Less & & & Matricaria chamomilla L. & & \\
\hline Eupatorium collinum DC. & & & Melampodium americanum L. & & \\
\hline Eupatorium leucocephalum Benth. & & & Melampodium divaricatum DC. & & \\
\hline Eupatorium schultzii Schnittsp. & & & Melampodium gracile Less. & & \\
\hline $\begin{array}{l}\text { Feischmannia capillipes (Benth. } \\
\text { ex Oerst.) R.M. King \& H. Rob. }\end{array}$ & & & $\begin{array}{l}\text { Melampodium microcephalum Less. } \\
\text { Melampodium perfoliatum Kunth }\end{array}$ & & \\
\hline $\begin{array}{l}\text { Feischmannia pycnocephala } \\
\text { (Less.) R.M. King \& H. Rob. }\end{array}$ & & & $\begin{array}{l}\text { Melanthera angustifolia A. Rich. } \\
\text { Melanthera aspera Steud. }\end{array}$ & & \\
\hline Forestina liebmannii Sch.Bip. & & & Melanthera nivea (L.) Small & & \\
\hline ex Greenm. & & & Mikania houstoniana B.L. Rob. & & \\
\hline Galeana pratensis Rydb. & & & Mikania pyramidata Donn. Sm. & & \\
\hline Galinsoga parviflora Cav. & & & Milleria quinqueflora L. & & \\
\hline Galinsoga quadriradiata Ruiz \& Pav. & & & Montanoa grandiflora DC. & & \\
\hline Gnaphalium attenuatum DC. & & & Montanoa tomentosa Cerv. & & \\
\hline Gnaphalium berlandieri DC. & & & Nelsonianthus tapianus (B.L. Turner) & & \\
\hline Gnaphalium canescens DC. & & & C. Jeffrey & & \\
\hline Gnaphalium leucocephalum A. & & & Neomirandea araliifolia (Less.) & & \\
\hline Gray & & & R.M. King \& H. Rob. & & \\
\hline Gnaphalium obtusifolium L. & & & Neurolaena lobata R. Br. & & \\
\hline Gnaphalium oxyphyllum DC. & & & Neurolaena macrophylla Greenm. & & \\
\hline Gnaphalium purpureum L. & & & Neurolaena venturana B.L. Turner & & \\
\hline Gynura aurantiaca DC. & & & Otopappus curviflorus Hemsl. & & \\
\hline Helenium quadridentatum Labill. & & & Oxylobus adscendens B.L. Rob. & & \\
\hline Helianthus annuus L. & & & \& Greenm. & & \\
\hline Heliopsis buphthalmoides Dunal & & & Packera coahuilensis (Greenm.) & & \\
\hline Heterosperma pinnatum Cav. & & & C. Jeffrey & & \\
\hline Heterotheca inuloides Cass. & & & Packera sanguisorbae (DC.) C. Jeffrey & & \\
\hline Hidalgoa ternata La Llave & & & Packera tampicana (DC.) C. & & \\
\hline Hieracium abscissum Less. & & & Jeffrey & & \\
\hline Hieracium pringlei A. Gray & & & Palafoxia lindenii A. Gray & & \\
\hline Hymenostephium guatemalense & & & Parthenium fruticosum Less. & & \\
\hline S.F. Blake & & & Pectis prostrata Cav. & & \\
\hline Isocarpha oppositifolia (L.) Cass. & & & Pentacalia parasitica (Hemsl.) & & \\
\hline Iva asperifolia Less. & & & H. Rob. \& Cuatrec. & & \\
\hline aegeria hirta (Lag.) Less. & & & Perymeniopsis ovalifolia (A. & & \\
\hline aegeria macrocephala Less. & & & Gray) H. rob. & & \\
\hline
\end{tabular}


Appendix 1. Continuation.

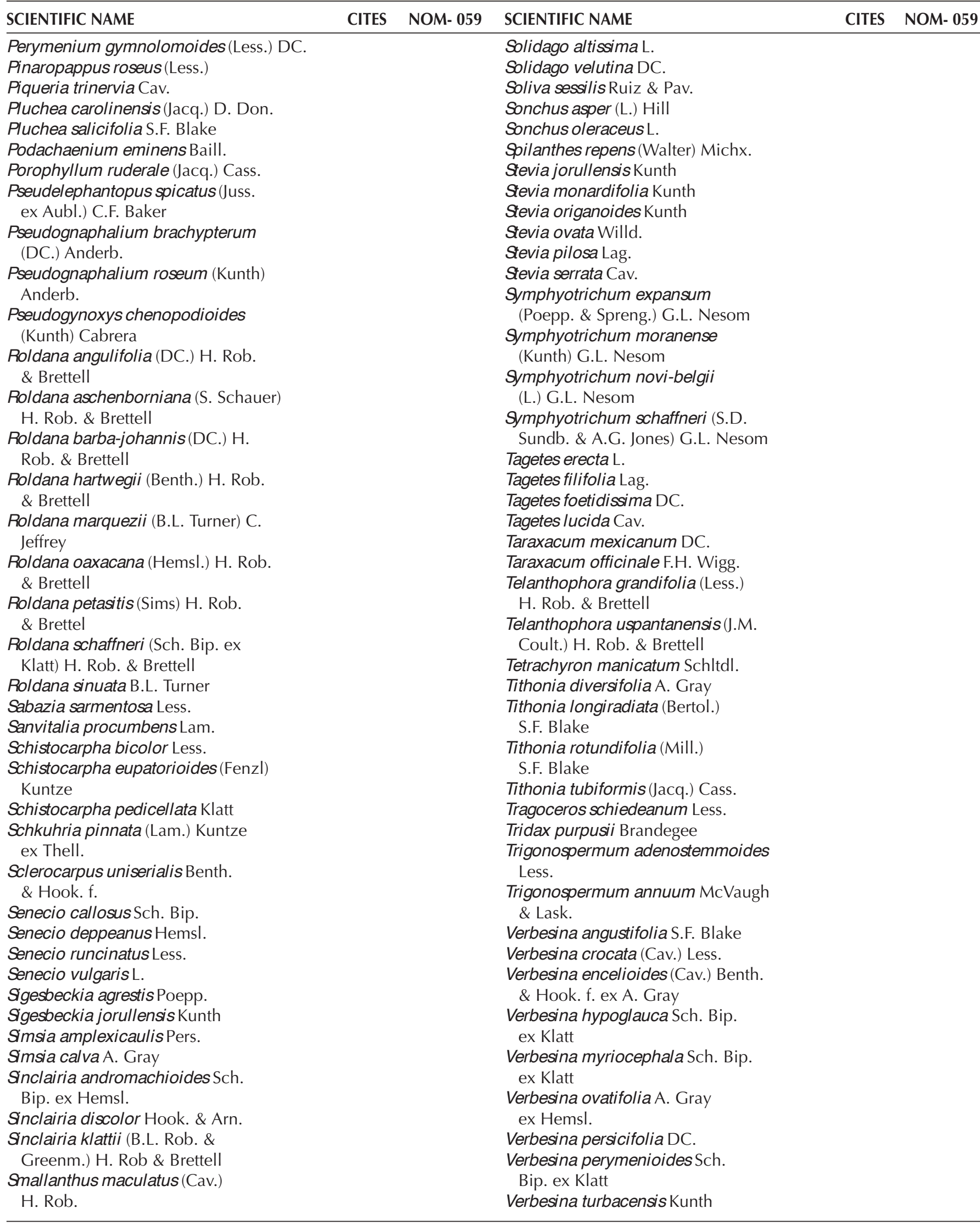


Appendix 1. Continuation.

\begin{tabular}{|c|c|c|c|c|c|}
\hline SCIENTIFIC NAME & CITES & NOM- 059 & SCIENTIFIC NAME & CITES & NOM- 059 \\
\hline Vernonanthura patens (Kunth) H. Rob. & & & Alnus jorullensis Kunth & & \\
\hline Vernonia arctioides Less. & & & Carpinus caroliniana Walter & & $\diamond$ \\
\hline Viguiera cordata (Hook. \& Arn.) & & & Ostrya virginiana Koch & & $\diamond$ \\
\hline D'Arcy & & & BIGNONIACEAE & & \\
\hline Viguiera grammatoglossa DC. & & & Amphilophium molle Schltdl. & & \\
\hline Wedelia acapulcensis Kunth & & & \& Cham. & & \\
\hline Xanthium strumarium L. & & & Amphitecna apiculata A.H. Gentry & & \\
\hline Youngia japonica(L.) DC. & & & Amphitecna latifolia (Mill.) A.H. & & \\
\hline Zinnia americana (Mill.) Olorode & & & Gentry & & \\
\hline \& A.M. Torres & & & Amphitecna tuxtlensis A.H. Gentry & & \\
\hline Zinnia peruviana (L.) L. & & & Anemopaegma puberulum & & \\
\hline ATHYRIACEAE & & & (Seibert) Miranda & & \\
\hline Diplazium cristatum Alston & & & Arrabidaea blanchetii A. DC. & & \\
\hline Diplazium donnell-smithii Christ & & & Arrabidaea inaequalis Baill. & & \\
\hline Diplazium franconis Liebm. & & & Bignonia alliacea Lam. & & \\
\hline Diplazium grandifolium Sw. & & & Crescentia alata Kunth & & \\
\hline Diplazium plantaginifolium & & & Crescentia cujete L. & & \\
\hline (L.) Urb. & & & Cydista potosina (K. Schum. \& & & \\
\hline Diplazium striatum (L.) Presl & & & Loes.) Loes. & & \\
\hline Diplazium ternatum Liebm. & & & Dolichandra quadrivalvis (Jacq.) & & \\
\hline Diplazium urticifolium Christ & & & L.G. Lohmann & & \\
\hline BALSAMINACEAE & & & acaranda mimosifolia D. Don & & \\
\hline Impatiens walleriana Hook. $\mathrm{f}$. & & & Macfadyena unguis-cati (L.) A.H. & & \\
\hline BASELLACEAE & & & Gentry & & \\
\hline Anredera cordifolia (Ten.) Steenis & & & Mansoa verrucifera (Schltdl.) A.H. & & \\
\hline Anredera vesicaria (Lam.) C.F. & & & Gentry & & \\
\hline Gaertn. & & & Parmentiera aculeata (Kunth) Seem. & & \\
\hline BATACEAE & & & Pithecoctenium crucigerum (L.) & & \\
\hline Batis maritima L. & & & A.H. Gentry & & \\
\hline BEGONIACEAE & & & Podranea ricasoliana Sprague & & \\
\hline Begonia barkeri Knowles \& Westc. & & & Tabebuia chrysantha (Jacq.) G. & & \\
\hline Begonia cucullata Willd. & & & Nicholson & & $\diamond$ \\
\hline Begonia fischeri Schrank & & & Tabebuia ochracea (Cham.) Standl. & & \\
\hline Begonia fusca Liebm. & & & Tabebuia rosea DC. & & \\
\hline Begonia glabra Aubl. & & & BIXACEAE & & \\
\hline Begonia gracilis Kunth & & & Amoreuxia wrightii A. Gray & & $\diamond$ \\
\hline Begonia heracleifolia Cham. & & & Bixa orellana L. & & \\
\hline \& Schltdl. & & & BLECHNACEAE & & \\
\hline Begonia incarnata Link \& Otto & & & Blechnum asplenioides Sw. & & \\
\hline Begonia ludicra A. DC. & & & Blechnum ensiforme (Liebm.) & & \\
\hline Begonia maculata Raddi & & & C. Chr. & & \\
\hline Begonia manicata Brongn. Cels & & & Blechnum falciforme (Liebm.) & & \\
\hline ex Vis. & & & C. Chr. & & \\
\hline Begonia multinervia Liebm. & & & Blechnum lehmannii Hieron. & & \\
\hline Begonia multistaminea Burt-Utley & & & Blechnum occidentale L. & & \\
\hline Begonia nelumbonifolia Schltdl. & & & Blechnum polypodioides Raddi & & \\
\hline \& Cham. & & & Blechnum pteropus (Kuntze) Mett. & & \\
\hline Begonia oaxacana A. DC. & & & Blechnum schiedeanum (Pr.) & & \\
\hline Begonia pudica L.B. Sm. \& B.G. & & & Hieron. & & \\
\hline Schub. & & & Blechnum stoloniferum Mett. & & \\
\hline BERBERIDACEAE & & & Blechnum varians (Fourn.) C. Chr. & & \\
\hline Berberis lanceolata Benth. & & & Woodwardia martinezii Maxon & & \\
\hline Berberis tenuifolia Lindl. & & & ex Weath. & & \\
\hline Mahonia russellii N.P. Taylor & & & Woodwardia spinulosa M. Martens & & \\
\hline BETULACEAE & & & \& Galeotti & & \\
\hline $\begin{array}{l}\text { Alnus acuminata subsp. arguta } \\
\text { (Schltdl.) Furlow }\end{array}$ & & & $\begin{array}{l}\text { Woodwardia } \times \text { semicordata Mickel } \\
\& \text { Beitel }\end{array}$ & & \\
\hline
\end{tabular}


Appendix 1. Continuation.

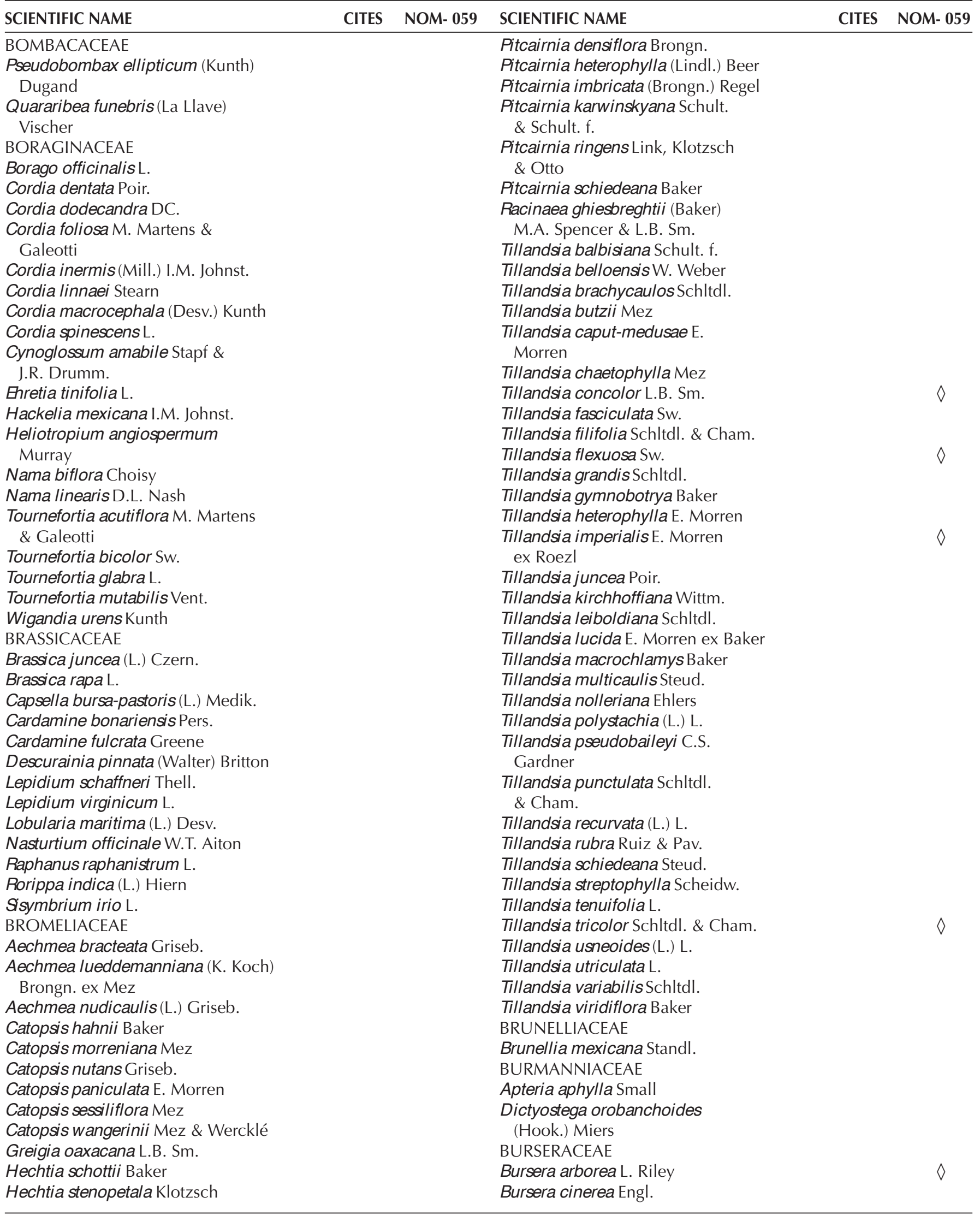


Appendix 1. Continuation.

\begin{tabular}{|c|c|c|c|c|c|}
\hline SCIENTIFIC NAME & CITES & NOM- 059 & SCIENTIFIC NAME & CITES & NOM- 059 \\
\hline Bursera grandifolia Engl. & & & Lobelia sartorii Vatke & & \\
\hline Bursera graveolens Triana \& Planch. & & & Lobelia tarsophora Seaton ex Green & & \\
\hline Bursera simaruba (L.) Sarg. & & & Lobelia xalapensis Kunth & & \\
\hline Protium copal (Schltdl. \& Cham.) & & & Triodanis perfoliata subsp. perfoliata & & \\
\hline Engl. & & & (L.) Nieuwl. & & \\
\hline CACTACEAE & & & CANNABACEAE & & \\
\hline $\begin{array}{l}\text { Acanthocereus tetragonus (L.) } \\
\text { Hummelinck }\end{array}$ & Appendix II & & $\begin{array}{l}\text { Aphananthe monoica (Hemsl.) } \\
\text { J.-F. Leroy }\end{array}$ & & \\
\hline Aporocactus flagelliformis Lem. & Appendix II & $\diamond$ & Celtis iguanaea (Jacq.) Sarg. & & \\
\hline Aporocactus martianus Britton \& Rose & Appendix II & & Lozanella enantiophylla (Donn. Sm.) & & \\
\hline $\begin{array}{l}\text { Cylindropuntia imbricata (Haw.) } \\
\text { F.M. Knuth }\end{array}$ & Appendix II & & $\begin{array}{l}\text { Killip \& C.V. Morton } \\
\text { Trema micrantha (L.) Blume }\end{array}$ & & \\
\hline $\begin{array}{l}\text { Disocactus ackermannii (Lindl.) } \\
\text { Barthlott }\end{array}$ & Appendix II & & $\begin{array}{l}\text { CANNACEAE } \\
\text { Canna generalis L.H. Bailey \& }\end{array}$ & & \\
\hline $\begin{array}{l}\text { Disocactus phyllanthoides (DC.) } \\
\text { Barthlott }\end{array}$ & Appendix II & $\diamond$ & $\begin{array}{l}\text { E.Z. Bailey } \\
\text { Canna indica L. }\end{array}$ & & \\
\hline Epiphyllum caudatum Britton \& Rose & Appendix II & & CAPPARACEAE & & \\
\hline Epiphyllum crenatum (Lindl.) G. Don & Appendix II & & Capparidastrum discolor (Donn. Sm.) & & \\
\hline Epiphyllum oxypetalum Haw. & Appendix II & & Cornejo \& Iltis & & \\
\hline Epiphyllum hookeri Haw. & Appendix II & & Capparidastrum mollicellum (Standl.) & & \\
\hline $\begin{array}{l}\text { Hylocereus undatus (Haw.) Britton } \\
\text { \& Rose }\end{array}$ & Appendix II & & $\begin{array}{l}\text { Cornejo \& Iltis } \\
\text { Capparidastrum quiriguense (Standl.) }\end{array}$ & & \\
\hline $\begin{array}{l}\text { Mammillaria eriacantha Link \& Otto } \\
\text { ex Pfeiff. }\end{array}$ & Appendix II & & $\begin{array}{l}\text { Cornejo \& Iltis } \\
\text { Capparis flexuosa (L.) L. }\end{array}$ & & \\
\hline Mammillaria sartorii J.A. Purpus & Appendix II & & Crateva tapia L. & & \\
\hline $\begin{array}{l}\text { Neobuxbaumia euphorbioides (Haw.) } \\
\text { Buxb. }\end{array}$ & Appendix II & & $\begin{array}{l}\text { Morisonia americana L. } \\
\text { Quadrella incana (Kunth) Iltis }\end{array}$ & & \\
\hline $\begin{array}{l}\text { Nopalxochia phyllanthoides(DC.) } \\
\text { Britton \& Rose }\end{array}$ & Appendix II & & $\begin{array}{l}\text { \& Cornejo } \\
\text { Quadrella pringlei (Briq.) Iltis }\end{array}$ & & \\
\hline Opuntia decumbens Salm-Dyck & Appendix II & & \& Cornejo & & \\
\hline Opuntia stricta (Haw.) Haw. & Appendix II & & CAPRIFOLIACEAE & & \\
\hline Pereskiopsis kellermanii Rose & & & Abelia floribunda Decne. & & \\
\hline $\begin{array}{l}\text { Pilosocereusleucocephalus (Poselger) } \\
\text { Byles \& G.D. Rowley }\end{array}$ & Appendix II & & $\begin{array}{l}\text { Lonicera japonica Thunb. } \\
\text { Valeriana clematitis Kunth }\end{array}$ & & \\
\hline $\begin{array}{l}\text { Pterocereus gaumeri (Britton \& Rose) } \\
\text { Th. MacDougall \& Miranda }\end{array}$ & Appendix II & $\diamond$ & $\begin{array}{l}\text { Valeriana scandens Loefl. } \\
\text { Valeriana urticifolia var. scorpioides }\end{array}$ & & \\
\hline Rhipsalis baccifera (Sol.) Stearn & Appendix II & & (DC.) Barrie & & \\
\hline $\begin{array}{l}\text { Selenicereus grandiflorus (L.) Britton } \\
\text { \& Rose }\end{array}$ & Appendix II & & $\begin{array}{l}\text { CARICACEAE } \\
\text { Carica cauliflora Jacq. }\end{array}$ & & \\
\hline $\begin{array}{l}\text { Selenicereus hamatus (Scheidw.) } \\
\text { Britton \& Rose }\end{array}$ & Appendix II & & $\begin{array}{l}\text { Carica papaya L. } \\
\text { acaratia mexicana A. DC. }\end{array}$ & & \\
\hline $\begin{array}{l}\text { Selenicereus testudo (Karw. ex Zucc.) } \\
\text { Buxb. }\end{array}$ & Appendix II & & $\begin{array}{l}\text { CARYOPHYLLACEAE } \\
\text { Arenaria decussata D.F.K. Schltdl. }\end{array}$ & & \\
\hline Stenocereus griseus (Haw.) Buxb. & Appendix II & & ex D.F.K. Schltdl. & & \\
\hline $\begin{array}{l}\text { Stenocereus pruinosus (Otto ex Pfeiff.) } \\
\text { Buxb. }\end{array}$ & Appendix II & & $\begin{array}{l}\text { Arenaria lanuginosa (Michx.) Rohrb. } \\
\text { Arenaria lycopodioides Willd. ex }\end{array}$ & & \\
\hline CALCEOLARIACEAE & & & D.F.K. Schltdl. & & \\
\hline Calceolaria mexicana Benth. & & & Arenaria reptans Hemsl. & & \\
\hline Calceolaria tripartita Ruiz \& Pav. & & & Cerastium glomeratum Thuill. & & \\
\hline CAMPANULACEAE & & & Drymaria cordata (L.) Willd. ex & & \\
\hline $\begin{array}{l}\text { Centropogon grandidentatus (Schltdl.) } \\
\text { Zahlbr. }\end{array}$ & & & $\begin{array}{l}\text { Roem. \& Schult. } \\
\text { Drymaria glandulosa Bartl. }\end{array}$ & & \\
\hline Diastatea micrantha (Kunth) McVaugh & & & Drymaria gracilis Cham. \& Schltdl. & & \\
\hline Hippobroma longiflora (L.) G. Don & & & Drymaria villosa Cham. \& Schltdl. & & \\
\hline Lobelia cardinalis L. & & & Stellaria media (L.) Vill. & & \\
\hline Lobelia Iaxiflora subsp. Iaxiflora Kunth & & & Stellaria nemorum L. & & \\
\hline Lobelia picta B.L. Rob. \& Seaton & & & Stellaria ovata Willd. ex D.F.K. Schltdl. & & \\
\hline
\end{tabular}


Appendix 1. Continuation.

\begin{tabular}{|c|c|c|c|c|c|}
\hline SCIENTIFIC NAME & CITES & NOM- 059 & SCIENTIFIC NAME & CITES & NOM- 059 \\
\hline CASUARINACEAE & & & COCHLOSPERMACEAE & & \\
\hline Casuarina equisetifolia L. & & & Cochlospermum vitifolium (Willd.) & & \\
\hline CELASTRACEAE & & & Spreng. & & \\
\hline Casearia aculeata Jacq. & & & COMBRETACEAE & & \\
\hline Celastrus pringlei Rose & & & Combretum farinosum Kunth & & \\
\hline Eaeodendron trichotomum (Turcz.) & & & Combretum fruticosum (Loefl.) Stuntz & & \\
\hline Lundell & & & COMMELINACEAE & & \\
\hline Euonymus benthamii Lundell & & & Aneilema geniculatum (Jacq.) & & \\
\hline Euonymus occidentalis Nutt. Ex Torr. & & & Woodson & & \\
\hline Hippocratea volubilis L. & & & Callisia fragrans (Lindl.) Woodson & & \\
\hline Maytenus texana Lundell & & & Callisia multiflora (M. Martens \& & & \\
\hline Perrottetia longistylis Rose & & & Galeotti) Standl. & & \\
\hline Perrottetia ovata Hemsl. & & & Callisia repens L. & & \\
\hline Pristimera celastroides (Kunth) & & & Campelia zanonia (L.) Kunth & & \\
\hline A.C. Sm. & & & Commelina diffusa Burm. f. & & \\
\hline Quetzalia schiedeana (Loes.) Lundell & & & Commelina rufipes var. glabrata (D.R. & & \\
\hline Quetzalia stipitata(Lundell) Lundell & & & Hunt) Faden \& D.R. Hunt & & \\
\hline Wimmeria bartlettii Lundell & & & Commelina tuberosa L. & & \\
\hline Wimmeria concolor Schltdl. \& Cham. & & & Gibasis geniculata (Jacq.) Rohweder & & \\
\hline Wimmeria persicifolia Radlk. & & & Gibasisoaxacana D.R. Hunt & & \\
\hline Zinowiewia integerrima Turcz. & & & Gibasispellucida (M. Martens \& & & \\
\hline CERATOPHYLLACEAE & & & Galeotti) D.R. Hunt & & \\
\hline Ceratophyllum demersum L. & & & Phaeosphaerion leiocarpum Hassk. & & \\
\hline CHLORANTHACEAE & & & ex C.B. Clarke & & \\
\hline Hedyosmum mexicanum C. Cordem. & & & Tinantia erecta (Jacq.) Fenzl & & \\
\hline CHRYSOBALANACEAE & & & Tinantia standleyi Steyerm. & & \\
\hline Couepia polyandra Rose & & & Tradescantia commelinoides Schult. & & \\
\hline Hirtella triandra Sw. & & & \& Schult.f. & & \\
\hline Licania platypus Fritsch & & & Tradescantia pallida (Rose) D.R. Hunt & & \\
\hline CIBOTIACEAE & & & Tradescantia spathacea Sw. & & \\
\hline Cibotium schiedei Schltdl. \& Cham. & & & Tradescantia zanonia (L.) Sw. & & \\
\hline CISTACEAE & & & Tradescantia zebrina Bosse & & \\
\hline Helianthemum coulteri S. Watson & & & Tripogandra disgrega (Kunth) Woodson & & \\
\hline CLEOMACEAE & & & Tripogandra purpurascens (S. Schauer) & & \\
\hline Andinocleome magnifica (Briq.) & & & Handlos & & \\
\hline Iltis \& Cochrane & & & Tripogandra serrulata (Vahl) Handlos & & \\
\hline Cleome aculeata L. & & & CONNARACEAE & & \\
\hline Cleome gigantea $\mathrm{L}$. & & & Rourea glabra Kunth & & \\
\hline Cleome guianensis Aubl. & & & CONVOLVULACEAE & & \\
\hline Cleome gynandra L. & & & Convolvulus nodiflorus Desr. & & \\
\hline Cleome speciosa Raf. & & & Cuscuta boldinghii Urb. & & \\
\hline Cleome spinosa Jacq. & & & Cuscuta jalapensis Schltdl. & & \\
\hline Cleome viscosa $\mathrm{L}$. & & & Cuscuta mitriformis Engelm. ex Hemsl. & & \\
\hline Tarenaya hassleriana (Chodat) Iltis & & & Dichondra argentea Humb. \& & & \\
\hline CLETHRACEAE & & & Bonpl. ex Willd. & & \\
\hline Clethra Ianata M. Martens \& Galeotti & & & Dichondra sericea Sw. & & \\
\hline Clethra macrophylla M. Martens & & & Evolvulus alsinoides L. & & \\
\hline \& Galeotti & & & Ipomoea affinis M. Martens \& Galeotti & & \\
\hline Clethra mexicana DC. & & & Ipomoea arborescens (Humb. \& & & \\
\hline Clethra pringlei S. Watson & & & Bonpl. ex Willd.) G. Don & & \\
\hline CLUSIACEAE & & & Ipomoea batatas (L.) Lam. & & \\
\hline Clusia guatemalensis Hemsl. & & & Ipomoea batatoides Choisy & & \\
\hline Clusia Iundellii Standl. & & & Ipomoea carnea Jacq. subsp. fistulosa & & \\
\hline Clusia quadrangula Bartlett & & & (Mart. ex Choisy) D.F. Austin & & \\
\hline Garcinia intermedia (Pittier) & & & Ipomoea cholulensis Kunth & & \\
\hline Hamel Mammea americana L. & & & Ipomoea costellata Torr. & & \\
\hline & & & Ipomoea dumosa (Benth.) L.O. Williams & & \\
\hline
\end{tabular}


Appendix 1. Continuation.

\begin{tabular}{|c|c|c|c|c|c|}
\hline SCIENTIFIC NAME & CITES & NOM- 059 & SCIENTIFIC NAME & CITES N & NOM- 059 \\
\hline Ipomoea hastigera Kunth & & & CUCURBITACEAE & & \\
\hline Ipomoea hederifolia L. & & & Cucumis anguria L. & & \\
\hline Ipomoea imperati (Vahl) Griseb. & & & Cucumis sativus L. & & \\
\hline Ipomoea indica (Burm.) Merr. & & & Cucurbita ficifolia Bouché & & \\
\hline Ipomoea jalapa (L.) Pursh & & & Cucurbita martinezii L.H. Bailey & & \\
\hline Ipomoea lindenii M. Martens & & & Cucurbita maxima Duchesne & & \\
\hline \& Galeotti & & & Cyclanthera dissecta (Torr. \& & & \\
\hline Ipomoea mairetii Choisy & & & A. Gray) Arn. & & \\
\hline Ipomoea neei (Spreng.) O'Donell & & & Cyclanthera explodens Naudin & & \\
\hline Ipomoea nil (L.) Roth & & & Cyclanthera langaei Cogn. & & \\
\hline Ipomoea pauciflora M. Martens & & & Cyclanthera ribiflora Cogn. & & \\
\hline \& Galeotti & & & Cyclanthera tamnoides Cogn. & & \\
\hline Ipomoea purga Hayne & & & Doyerea emetocathartica Grosourdy & & \\
\hline Ipomoea purpurea (L.) Roth & & & Hanburia mexicana Seem. & & \\
\hline Ipomoea setosa Ker Gawl. & & & Lagenaria siceraria (Molina) Standl. & & \\
\hline Ipomoea wolcottiana Rose & & & Luffa cylindrica M. Roem. & & \\
\hline Jacquemontia oaxacana (Meisn.) & & & Melothria pendula L. & & \\
\hline Hallier $\mathrm{f}$. & & & Microsechium palmatum Cogn. & & \\
\hline acquemontia sphaerostigma Rusby & & & Momordica charantia L. & & \\
\hline acquemontia tamnifolia (L.) Griseb. & & & Sechium edule Sw. & & \\
\hline Merremia dissecta Hallier f. & & & Scydium schiedeanum Schltdl. & & \\
\hline Merremia quinquefolia Hallier $\mathrm{f}$. & & & Sicyos longisepalus Cogn. & & \\
\hline Merremia umbellata (L.) Hallier f. & & & Scyos microphyllus Kunth & & \\
\hline Turbina corymbosa (L.) Raf. & & & Vaseyanthus insularis Rose & & \\
\hline CORNACEAE & & & CUNONIACEAE & & \\
\hline Cornus disciflora Moc. \& Sessé ex DC. & & & Weinmannia balbisiana Kunth & & \\
\hline Cornus excelsa Kunth & & & Weinmannia pinnata L. & & \\
\hline Costus dirzoi García-Mend. \& & & & CUPRESSACEAE & & \\
\hline Ibarra-Manr. & & & Cupressus lindleyi Klotzsch ex Endl. & & \\
\hline Costus pictus D. Don ex Lindl. & & & Cupressus I usitanica Mill. & & $\diamond$ \\
\hline Costus pulverulentus C. Presl & & & Taxodium mucronatum Ten. & & \\
\hline CRASSULACEAE & & & CYATHEACEAE & & \\
\hline Bryophyllum delagoensis (Eckl. \& & & & Cyathea bicrenata Liebm. & Appendix II & \\
\hline Zeyh.) Schinz & & & Cyathea divergens Kunze & & $\diamond$ \\
\hline Echeveria amoena D. Smet ex E. Morren & & & Cyathea divergens var. tuerckheimii & Appendix II & \\
\hline Echeveria atropurpurea (Baker) & & & (Maxon) R.M. Tryon & & \\
\hline É. Morren & & & Cyathea fulva Fée & Appendix II & $\diamond$ \\
\hline Echeveria microcalyx Britton \& Rose & & & Nephelea mexicana (Schltdl. \& Cham.) & & $\diamond$ \\
\hline Echeveria racemosa var. citrina & & & R.M. Tryon & & \\
\hline Kimnach & & & Sphaeropteris horrida (Liebm.) R.M. Tryon & & $\diamond$ \\
\hline Echeveria rosea Lindl. & & & Trichipteris schiedeana (C. Presl) & & \\
\hline Kalanchoe pinnata Pers. & & & R.M. Tryon & & \\
\hline Sedum adolphi Raym.-Hamet & & & CYCLANTHACEAE & & \\
\hline Sedum botterii Hemsl. & & & Asplundia Iabela (R.E. Schult.) Harling & & \\
\hline Sedum confusum Hemsl. & & & Asplundia liebmanniii Harling & & \\
\hline Sedum dendroideum Moc. \& & & & CYPERACEAE & & \\
\hline Sessé ex DC. & & & Bulbostylis capillaris(L.) Kunth & & \\
\hline Sedum goldmanii (Rose) Moran & & & ex C.B. Clarke & & \\
\hline Sedum hemsleyanum Rose & & & Bulbostylisjuncoides (Vahl) Kük. & & \\
\hline Sedum hultenii Fröd. & & & ex Osten & & \\
\hline Sedum moranense Kunth & & & Carex chordalis Liebm. & & \\
\hline Sedum nussbaumerianum Bitter & & & Carex longii Mack. & & \\
\hline Sedum palmeri S. Watson & & & Carex Iurida Wahlenb. & & \\
\hline Villadia jurgensenii (Hemsl.) Jacobsen & & & Carex melanosperma Liebm. & & \\
\hline Villadia mexicana (Schltdl.) H. & & & Carex perlonga Fernald & & \\
\hline Jacobsen & & & Carex physorhyncha Liebm. ex Steud. & & \\
\hline & & & Carex polystachya Sw. ex Wahlenb. & & \\
\hline
\end{tabular}


Appendix 1. Continuation.

\begin{tabular}{|c|c|c|c|c|c|}
\hline SCIENTIFIC NAME & CITES & NOM- 059 & SCIENTIFIC NAME & CITES & NOM- 059 \\
\hline Carex standleyana Steyerm. & & & DILLENIACEAE & & \\
\hline Carex vulpinoidea Michx. & & & Tetracera erecta Sessé \& Moc. ex DC. & & \\
\hline Cyperus aggregatus Endl. & & & DIOSCOREACEAE & & \\
\hline Cyperus digitatus Roxb. & & & Dioscorea composita Hemsl. & & \\
\hline Cyperus filiculmis Vahl & & & Dioscorea convolvulacea Cham. \& & & \\
\hline Cyperusflavus J. Presl \& C. Presl & & & Schltdl. & & \\
\hline Cyperus haspan L. & & & Dioscorea cruzensis R. Knuth & & \\
\hline Cyperus hermaphroditus Standl. & & & Dioscorea floribunda M. Martens \& & & \\
\hline Cyperus involucratus Rottb. & & & Galeotti & & \\
\hline Cyperus laxus Lam. & & & Dioscorea mexicana Scheidw. & & \\
\hline Cyperus/uzulae (L.) Rottb. ex Retz. & & & Dioscorea pallens Schltdl. & & \\
\hline Cyperus mutisii Andersson & & & Dioscorea polygonoides Humb. \& & & \\
\hline Cyperus odoratus L. & & & Bonpl. ex Willd. & & \\
\hline Cyperus spectabilis Link & & & Dioscorea spiculiflora var. & & \\
\hline Cyperus tenuis Sw. & & & fasciculocongesta V. Sosa \& B.G. & & \\
\hline Cyperus thyrsiflorus Jungh. & & & DRYOPTERIDACEAE & & \\
\hline Cyperus virens Michx. & & & Arachniodes denticulata (Sw.) Ching & & \\
\hline Beocharis geniculata (L.) Roem. & & & Bolbitis hastata (E. Fourn.) Hennipman & & \\
\hline \& Schult. & & & Bolbitis semipinnatifida (Fée) Alston & & \\
\hline Beocharis minima Kunth & & & Ctenitis equestris var. equestris & & \\
\hline Eeocharis montana Roem. \& Schult. & & & (Kunze) Ching & & \\
\hline Eeocharis nervata Svenson & & & Ctenitis melanosticta (Kunze) Copel. & & \\
\hline Fimbristylis autumnalis Roem. \& Schult. & & & Cystopteris fragilis (L.) Bernh. & & \\
\hline Kyllinga brevifolia Rottb. & & & Didymochlaena truncatula (Sw.) J. Sm. & & \\
\hline Kyllinga odorata Vahl & & & Dryopteris filix-mas (L.) Schott & & \\
\hline Kyllinga pumila Michx. & & & Dryopteris maxonii Underw. \& C. Chr. & & \\
\hline Rhynchospora nervosa Boeckeler & & & Dryopteris patula (Sw.) Underw. & & \\
\hline Rhynchospora aristata Boeckeler & & & Dryopteris wallichiana (Spreng.) Hyl. & & \\
\hline Rhynchospora corymbosa (L.) Britton & & & Baphoglossum davidsei Mickel & & \\
\hline Rhynchospora dives Standl. & & & Baphoglossum guatemalense & & \\
\hline Rhynchospora polyphylla (Vahl) Vahl & & & (Klotzsch) T. Moore & & \\
\hline $\begin{array}{l}\text { Rhynchospora radicans subsp. radicans } \\
\text { (Schltdl. \& Cham.) H. Pfeiff. }\end{array}$ & & & $\begin{array}{l}\text { 日aphoglossum mesoamericanum } \\
\text { A. Rojas }\end{array}$ & & \\
\hline Rhynchospora schiedeana Kunth & & & Baphoglossum obovatum Mickel & & \\
\hline Rhynchospora scutellata Griseb. & & & Baphoglossum petiolatum (Sw.) Urb. & & \\
\hline Scleria bracteata Cav. & & & Baphoglossum seminudum Mickel & & \\
\hline Scleria macrophylla J. Presl \& C. Presl & & & Baphoglossum vestitum (Schltdl. & & \\
\hline Scleria melaleuca Rchb. ex Schltdl. & & & \& Cham.) T. Moore & & \\
\hline \& Cham. & & & Lastreopsis effusa (Sw.) Tindale & & \\
\hline Scleria oligantha Michx. & & & Megalastrum subincisum (Willd.) A.R. & & \\
\hline Uncinia hamata Urb. & & & Sm. \& R.C. Moran & & \\
\hline CYTINACEAE & & & Phanerophlebia gastonyi Yatsk. & & \\
\hline Bdallophytum americanum (R. Br.) & & & Phanerophlebia macrosora (Baker) & & \\
\hline Harms & & & Underw. & & \\
\hline DAVALLIACEAE & & & Phanerophlebia nobilis var. remotispora & & \\
\hline Nephrolepis exaltata (L.) Schott & & & (E. Fourn.) Yatsk. & & \\
\hline DENNSTAEDTIACEAE & & & Phanerophlebia remotispora E. Fourn. & & \\
\hline Dennstaedtia bipinnata (Cav.) Maxon & & & Polystichum hartwegii (Klotzsch) Hieron. & & \\
\hline Dennstaedtia dissecta (Sw.) T. Moore & & & Polystichum mickelii A.R. Sm. & & \\
\hline Hypolepis blepharochlaena Mickel & & & Polystichum muricatum Fée & & \\
\hline \& Beitel & & & Stigmatopteris longicaudata (Liebm.) & & \\
\hline Pteridium caudatum (L.) Maxon & & & C. Chr. & & \\
\hline DICKSONIACEAE & & & EBENACEAE & & \\
\hline Dicksonia sellowiana Hook. & Appendix II & $\diamond$ & Diospyros riojae Gómez Pompa & & $\Delta$ \\
\hline Lophosoria quadripinnata (J.F. Gmel.) & & & Diospyros verae-crucis Standl. & & \\
\hline C. Chr. & & & EQUISETACEAE & & \\
\hline & & & Equisetum giganteum L. & & \\
\hline
\end{tabular}


Appendix 1. Continuation.

\section{$\frac{\text { SCIENTIFIC NAME }}{\text { Equisetum hyemale L. }}$}

Equisetum myriochaetum Schltdl. \& Cham.

ERICACEAE

Agarista mexicana (Hemsl.) Judd

Andromeda squamulosa D. Don

Arbutus xalapensis Kunth

Bejaria aestuans Loefl.

Chimaphila maculata (L.) Pursh

Chimaphila umbellata (L.) W.P.C. Barton

Comarostaphylis discolor (Hook.) Diggs

Gaultheria acuminata Cham. \& Schltdl.

Gaultheria erecta Banks \& Sol. Ex

Hook. f.

Lyonia ferruginea (Walter) Nutt.

Lyonia squamulosa M. Martens \&

Galeotti

Monotropa uniflora L.

Pernettya prostrata Sleumer

Pyrola angustifolia (Alef.) Hemsl.

Vaccinium confertum Kunth

Vaccinium leucanthum Schltdl.

EUPHORBIACEAE

Acalypha adenostachya Müll. Arg.

Acalypha alopecuroidea Jacq.

Acalypha arvensis Poepp.

Acalypha botteriana Müll. Arg.

Acalypha diversifolia Jacq.

Acalypha hispida Burm. f.

Acalypha indica L.

Acalypha leptopoda Müll. Arg.

Acalypha longistipularis Müll. Arg.

Acalypha mollis Kunth

Acalypha neomexicana Müll. Arg.

Acalypha pohliana Müll. Arg.

Acalypha poiretii Spreng.

Acalypha schiedeana Schltdl.

Acalypha schlechtendaliana Müll. Arg.

Acalypha schlumbergeri Müll. Arg.

Acalypha setosa A. Rich.

Acalypha subviscida S. Watson

Acalypha villosa Jacq.

Acalypha wilkesiana Müll. Arg.

Adelia barbinervis Cham. \& Schltdl.

Adelia oaxacana Hemsl.

Alchornea latifolia Sw.

Argythamnia heterantha (Zucc.)

Müll. Arg.

Bernardia dodecandra (Sessé ex

Cav.) McVaugh

Bernardia macrocarpa A.Cerv.

\& Flores Olv.

Bernardia mexicana Müll. Arg.

Caperonia palustris Kunth

Chamaesyce densiflora (Klotzsch

\& Garcke) Millsp.

Chamaesyce hirta (L.) Millsp.

Chamaesyce stictospora (Engelm.) Small
CITES NOM- 059 SCIENTIFIC NAME

CITES NOM- 059

Cnidoscolus aconitifolius (Mill.)

I.M. Johnst.

Cnidoscolus multilobus (Pax) I.M.

Johnst.

Cnidoscolus tubulosus I.M. Johnst.

Codiaeum variegatum (L.) A. Juss.

Croton billbergianus Müll. Arg.

Croton ciliatoglandulifer Ortega

Croton ciliatoglandulosus Ortega

$\diamond \quad$ ex Steud.

Croton discolor Willd.

Croton draco Schltdl.

Croton flavens $\mathrm{L}$.

Croton hirtus L'Hér.

Croton liebmannii Müll. Arg.

Croton lobatus L.

Croton miradorensis Müll. Arg.

Croton nitens Sw.

Croton niveus Jacq.

Croton panamensis Müll. Arg.

Croton punctatus Retz.

Croton reflexifolius Kunth

Croton repens Schltdl.

Croton schiedeanus Schltdl.

Croton soliman Cham. \& Schltdl.

Croton stipulaceus Kunth

Croton suberosus Kunth

Croton xalapensis Kunth

Dalechampia scandens L.

Ditaxis guatemalensis Pax \& K. Hoffm.

Euphorbia prostrata Aiton

Euphorbia calcarata (Schltdl.)

V.W. Steinm.

Euphorbia cyathophora Murray

Euphorbia cymosa Poir.

Euphorbia delicatula Boiss.

Euphorbia densiflora (Klotzsch \&

Garcke) Klotzsch

Euphorbia dentata Michx.

Euphorbia dioeca Kunth

Euphorbia filiformis (P.R.O. Bally) Bruyns

Euphorbia finkii (Boiss.) V.W. Steinm.

Euphorbia graminea Jacq.

Euphorbia heterophylla L.

Euphorbia hirta L.

Euphorbia hypericifolia L.

Euphorbia hyssopifolia L.

Euphorbia ixtlana Huft

Euphorbia lancifolia Schltdl.

Euphorbia macropus Boiss.

Euphorbia maculata L.

Euphorbia marginata Pursh

Euphorbia mendezii Boiss.

Euphorbia neriifolia L.

Euphorbia nutans Lag.

Euphorbia ocymoidea L.

Euphorbia orizabae Boiss.
Appendix II

Appendix II

Appendix II Appendix II Appendix II Appendix II

Appendix II Appendix II Appendix II Appendix II Appendix II Appendix II Appendix II Appendix II Appendix II Appendix II Appendix II Appendix II Appendix II Appendix II Appendix II

Appendix II Appendix II Appendix II 
Appendix 1. Continuation.

\begin{tabular}{|c|c|c|c|c|}
\hline SCIENTIFIC NAME & NOM- 059 & SCIENTIFIC NAME & CITES & NOM- 059 \\
\hline Euphorbia schlechtendalii Boiss. & Appendix II & Calliandra spraguei (Britton \& Rose) & & \\
\hline Euphorbia subreniformis S. Watson & Appendix II & Lundell & & \\
\hline Euphorbia tithymaloides L. & Appendix II & Calliandra tergemina (L.) Benth. & & \\
\hline Euphorbia xalapensis Kunth & Appendix II & Calopogonium mucunoides Desv. & & \\
\hline Garcia nutans Rohr & & Canavalia brasiliensis Mart. ex Benth. & & \\
\hline Gymnanthes actinostemoides Müll. Arg. & & Cassia grandis L. f. & & \\
\hline Gymnanthes Iongipes Müll. Arg. & & Centrosema pascuorum Mart. ex Benth. & & \\
\hline Gymnanthes riparia Klotzsch & & Centrosema plumieri Benth. & & \\
\hline Jatropha curcas L. & & Centrosema virginianum (L.) Benth. & & \\
\hline atropha podagrica Hook. & & Chamaecrista diphylla(L.) Greene & & \\
\hline Manihot aesculifolia Pohl & & Chamaecrista glandulosa Greene & & \\
\hline Manihot rhomboidea Mull Arg. & & Chamaecrista hispidula (Vahl) H.S. & & \\
\hline Pleradenophora tuerckheimiana (Pax & & Irwin \& Barneby & & \\
\hline \& K. Hoffm.) A. L. Melo \& Esser & & Chamaecrista kunthiana (Schltdl.) \& & & \\
\hline Plukenetia volubilis L. & & Cham.) H.S. Irwin \& Barneby & & \\
\hline Ricinus communis $\mathrm{L}$. & & Chamaecrista rufa Britton \& Rose & & \\
\hline Sapium lateriflorum Hemsl. & & Chloroleucon mangense (Jacq.) & & \\
\hline Sebastiania pavoniana Müll. Arg. & & Britton \& Rose & & \\
\hline Tragia nepetifolia Cav. & & Clitoria falcata Lam. & & \\
\hline Tragia yucatanensis Millsp. & & Clitoria mexicana Link & & \\
\hline FABACEAE & & Cojoba arborea (L.) Britton \& Rose & & \\
\hline Abrus precatorius L. & & Cologania broussonetii DC. & & \\
\hline Acacia angustissima (Mill.) Kuntze & & Cologania hirta Rose & & \\
\hline Acacia berlandieri Benth. & & Coursetia caribaea var. caribaea & & \\
\hline Acacia glauca (L.) Moench & & (Jacq.) Lavin & & \\
\hline $\begin{array}{l}\text { Acacia macracantha Humb. \& Bonpl. } \\
\text { ex Willd. }\end{array}$ & & $\begin{array}{l}\text { Crotalaria bupleurifolia Schltdl. \& Cham. } \\
\text { Crotalaria incana L. }\end{array}$ & & \\
\hline Acacia sphaerocephala Cham. \& Schltdl. & & Crotalaria maypurensis Kunth & & \\
\hline Acacia tortuosa (L.) Willd. & & Crotalaria micans Link & & \\
\hline Aeschynomene fascicularis Cham. & & Crotalaria nitens Kunth & & \\
\hline \& Schltdl. & & Crotalaria pumila Ortega & & \\
\hline Aeschynomene purpusii Brandegee & & Crotalaria quercetorum Brandegee & & \\
\hline Albizia tomentosa Standl. & & Crotalaria rotundifolia (Walter) J.F. Gmel. & & \\
\hline Amicia zygomeris DC. & & Crotalaria rzedowskii J. Espinosa & & \\
\hline Amphicarpaea bracteata (L.) Fernald & & Crotalaria sagittalis L. & & \\
\hline Andira inermis (W. Wright) DC. & & Dalbergia monetaria L.f. & & \\
\hline Arachis hypogaea L. & & Dalea carthagenensis (Jacq.) J.F. Macbr. & & \\
\hline Bauhinia divaricata $\mathrm{L}$. & & Dalea foliolosa (Aiton) Barneby var. & & \\
\hline Bauhinia latifolia Cav. & & citrina (Rydb.) Barneby & & \\
\hline Bauhinia mexicana Vogel & & Dalea leporina (Aiton) Bullock & & \\
\hline Bauhinia purpurea L. & & Dalea scandens var. scandens (Mill.) & & \\
\hline Caesalpinia bonduc Roxb. & & R.T. Clausen & & \\
\hline Caesalpinia cacalaco Bonpl. & & Desmanthus virgatus (L.) Willd. & & \\
\hline Caesalpinia pulcherrima (L.) Sw. & & Desmodium adscendens(Sw.) DC. & & \\
\hline Cajanus cajan (L.) Huth & & Desmodium affine Schltdl. & & \\
\hline Calliandra anomala (Kunth) J.F. Macbr. & & Desmodium angustifolium (Kunth) DC. & & \\
\hline Calliandra capillata Benth. & & Desmodium axillare DC. & & \\
\hline Calliandra emarginata (Humb. \& & & Desmodium caripense (Kunth) G. Don & & \\
\hline Bonpl. ex Willd.) Benth. & & Desmodium distortum (Aubl.) J.F. Macbr. & & \\
\hline Calliandra houstoniana (Mill.) Standl. & & Desmodium glutinosum (Muhl. ex & & \\
\hline Calliandra laxa (Willd.) Benth. & & Willd.) Wood & & \\
\hline Calliandra palmeri S. Watson & & Desmodium grahamii A. Gray & & \\
\hline Calliandra portoricensis (Jacq.) Benth. & & Desmodium helleri Peyr. & & \\
\hline Calliandra rubescens (M. Martens & & Desmodium incanum (G.Mey.) DC. & & \\
\hline \& Galeotti) Standl. & & Desmodium infractum DC. & & \\
\hline Calliandra rupestris Brandegee & & $\begin{array}{l}\text { Desmodium intortum (Mill.) Urb. } \\
\text { Desmodium leptoclados Hemsl. }\end{array}$ & & \\
\hline
\end{tabular}


Appendix 1. Continuation.

$\frac{\text { SCIENTIFIC NAME }}{\text { Desmodium nicaraguense Oerst. Ex }}$

Benth. \& Orst.

Desmodium nudiflorum (L.) DC.

Desmodium orbiculare Schltdl.

Desmodium plicatum Cham. \& Schltdl.

Desmodium prehensile Schltdl.

Desmodium procumbens (Mill.) Hitchc.

Desmodium psilophyllum Schltdl.

Desmodium purpusii Brandegee

Desmodium sessilifolium Torr.

\& A. Gray

Desmodium strobilaceum Schltdl.

Desmodium tortuosum (Sw.) DC.

Diphysa carthagenensis Jacq.

Diphysa macrophylla Lundell

Diphysa minutifolia Rose

Diphysa sennoides Benth. ex

Benth. \& Oerst.

Dussia mexicana Harms

Enterolobium cyclocarpum

(Jacq.) Griseb.

Eriosema diffusum G. Don

Eriosema grandiflorum G. Don

Erythrina americana Mill.

Eythrina berenices Krukoff \& Barneby

Erythrina flabelliformis Kearney

Erythrina folkersii Krukoff \& Moldenke

Eysenhardtia polystachya (Ortega) Sarg.

Galactia striata Urb.

Gliricidia sepium Kunth

Indigofera jamaicensis Spreng.

Indigofera thibaudiana DC.

Inga flexuosa Graham

Inga jinicuil Schltdl.

Inga latibracteata Harms

Inga micheliana Harms

Inga paterno Harms

Inga punctata Willd.

Inga sapindoides Willd.

Inga vera Willd.

Lennea brunnescens Standl.

Lennea melanocarpa Vatke ex Harms

Leucaena diversifolia Benth.

Leucaena lanceolata S. Watson

Leucaena leucocephala (Lam.) de Wit

Leucaena pulverulenta Benth.

Lonchocarpus guatemalensis Benth.

Lonchocarpus santarosanus Donn. Sm.

Lotus angustifolius Gouan

Lupinus elegans Kunth

Lysiloma acapulcense (Kunth) Benth.

Lysiloma auritum (Schltdl.) Benth.

Lysiloma divaricatum Benth

Lysiloma microphyllum Benth.

Machaerium biovulatum Micheli

Machaerium chiapense Brandegee

Macroptilium atropurpureum Urb.
CITES NOM- 059 SCIENTIFIC NAME

CITES NOM- 059

Macroptilium gibbosifolium (Ortega)

A. Delgado

Macroptilium lathyroides (L.) Urb

Marina scopa Barneby

Medicago lupulina L.

Melilotus indicus (L.) All.

Mimosa affinis B.L. Rob.

Mimosa albida Humb. \& Bonpl.

ex Willd.

Mimosa caerulea Rose

Mimosa ervendbergii A. Gray

Mimosa invisa Mart. ex Colla

Mimosa pigra L.

Mimosa polyantha Willd.

Mimosa pudica L.

Mucuna argyrophylla Standl.

Mucuna jarocha T.M. Moura, Mansano,

Gereau \& A.M.G. Azevedo

Mucuna pruriens (L.) DC.

Phaseolus anisotrichos Schltdl.

Phaseolus coccineus L.

Phaseolus glabellus Piper

Phaseolus lunatus L.

Phaseolus pedicellatus Benth.

Phaseolus vulgaris $\mathrm{L}$.

Piscidia piscipula (L.) Sarg.

Pithecellobium lanceolatum Benth.

Rhynchosia erythrinoides Schltdl.

\& Cham.

Rhynchosia longeracemosa M.

Martens \& Galeotti

Rhynchosia phaseoloides (Sw.) DC.

Rhynchosia pyramidalis Urb.

Senna atomaria (L.) H.S. Irwin \&

Barneby

Senna bacillaris (L.f.) H.S. Irwin \& Barneby

Senna cobanensis (Britton) H.S. Irwin \& Barneby

Senna didymobotrya (Fresen.) H. S. Irwin \& Barnby

Senna fruticosa (Mill.) H.S. Irwin \& Barneby

Senna leiophylla (Vogel) H.S. Irwin

\& Barneby

Senna mexicana (Jacq.) H.S. Irwin

\& Barneby

Senna multiglandulosa (Jacq.) H.S.

Irwin \& Barneby

Senna occidentalis (L.) Link

Senna pallida (Vahl) H.S. Irwin \&

Barneby

Senna papillosa (Britton \& Rose) H.S. Irwin \& Barneby

Senna pendula (Humb. \& Bonpl. ex Willd.) H.S. Irwin \& Barneby 
Appendix 1. Continuation.

\begin{tabular}{|c|c|c|c|c|c|}
\hline SCIENTIFIC NAME & CITES & NOM- 059 & SCIENTIFIC NAME & CITES & NOM- 059 \\
\hline Senna septemtrionalis(Viv.) H.S. & & & Quercus sebifera Trel. & & \\
\hline Irwin \& Barneby & & & Quercus splendens Née & & \\
\hline Senna spectabilis (DC.) H.S. Irwin & & & Quercus xalapensis Bonpl. & & \\
\hline \& Barneby & & & GARRYACEAE & & \\
\hline Senna uniflora (Mill.) H.S. Irwin \& & & & Garrya Iaurifolia Hartw. ex Benth. & & \\
\hline Barneby & & & GELSEMIACEAE & & \\
\hline Senna villosa (Mill.) H.S. Irwin \& Barneby & & & Gelsemium sempervirens (L.) J. St.- Hil. & & \\
\hline Stylosanthes guianensis (Aubl.) Sw. & & & GENTIANACEAE & & \\
\hline Stylosanthes humilis Kunth & & & Gentiana ovatiloba Kusnezow & & \\
\hline Stylosanthes viscosa (L.) Sw. & & & Gentiana spathacea Kunth & & $\Delta$ \\
\hline Tamarindus indica L. & & & Halenia brevicornis(Kunth) G. Don & & \\
\hline Tephrosia belizensis Lundell & & & Halenia schiedeana Griseb. & & \\
\hline Tephrosia nitens Benth. & & & GERANIACEAE & & \\
\hline Tephrosia vicioides Schltdl. & & & Erodium cicutarium (L.) L'Hér. ex Aiton & & \\
\hline Teramnus labialis (L.f.) Spreng. & & & Geranium schiedeanum Schltdl. & & \\
\hline Trifolium amabile Kunth & & & Geranium seemannii Peyr. & & \\
\hline Trifolium repens $\mathrm{L}$. & & & Pelargonium peltatum (L.) L'Hér. & & \\
\hline Vicia faba L. & & & GESNERIACEAE & & \\
\hline Vigna Iuteola (Jacq.) Benth. & & & Besleria cyrtanthemum Hanst. & & \\
\hline Vigna speciosa (Kunth) Verdc. & & & Columnea schiedeana Schltdl. & & \\
\hline Vigna vexillata (L.) A. Rich. & & & Kohleria deppeana (Schltdl. \& Cham.) & & \\
\hline Zapoteca Formosa (Kunth) H.M. Hern. & & & Fritsch & & \\
\hline Zapoteca lambertiana (G. Don) & & & Kohleria elegans Loes. & & \\
\hline H.M. Hern. & & & Kohleria papillosa Fritsch & & \\
\hline Zapoteca portoricensis (Jacq.) & & & Kohleria rugata (Scheidw.) L.P. Kvist & & \\
\hline H.M. Hern. & & & \& L.E. Skog & & \\
\hline Zornia reticulata Sm. & & & Kohleria spicata (Kunth) Oerst. & & \\
\hline Zygia cognata (Schltdl.) Britton \& Rose & & & Kohleria viminalis Brandegee & & \\
\hline FAGACEAE & & & Moussonia deppeana (Schltdl. \& & & \\
\hline Fagus grandifolia Ehrh. var. mexicana & & $\diamond$ & Cham.) Hanst. & & \\
\hline (Martínez) Little & & & Moussonia fruticosa (Brandegee) Wiehler & & \\
\hline Quercus acutifolia Née & & & Moussonia triflora Hanst. & & \\
\hline Quercus affinis Scheidw. & & & Rhynchoglossum azureum (Schltdl.) & & \\
\hline Quercus candicans Née & & & B.L. Burtt & & \\
\hline Quercus castanea Née & & & Snningia speciosa Hiern & & \\
\hline Quercus conspersa Benth & & & Smithiantha zebrine Kuntze & & \\
\hline Quercus cortesii Liebm. & & & Solenophora glomerata Weigend & & \\
\hline Quercus crassifolia Bonpl. & & & \& Förther & & \\
\hline Quercus crassipes Bonpl. & & & GLEICHENIACEAE & & \\
\hline Quercus depressa Bonpl. & & & Diplopterygium bancroftii (Hook. ) & & \\
\hline Quercus elliptica Née & & & A.R. Sm. & & \\
\hline Quercus germana Schltdl. \& Cham. & & & Gleichenella pectinata (Willd.) Ching & & \\
\hline Quercus ghiesbreghtii M. Martens \& & & & Gleichenia palmata (Schaffn.) T. Moore & & \\
\hline Galeotti & & & Sicherus bifidus (Willd.) Ching & & \\
\hline Quercus glabrescens Benth. & & & GUNNERACEAE & & \\
\hline Quercus laeta Liebm. & & & Gunnera mexicana Brandegee & & \\
\hline Quercus Iancifolia Schltdl. \& Cham. & & & HAMAMELIDACEAE & & \\
\hline Quercus laurina Bonpl. & & & Hamamelis virginiana L. & & \\
\hline Quercus obtusata Bonpl. & & & Matudaea trinervia Lundell & & $\Delta$ \\
\hline Quercus oleoides Schltdl. \& Cham. & & & HELICONIACEAE & & \\
\hline Quercus peduncularis Née & & & Heliconia adflexa Standl. & & \\
\hline Quercus pinnativenulosa C.H. Mull. & & & Heliconia latispatha Benth. & & \\
\hline Quercus polymorpha Schltdl. \& Cham. & & & Heliconia schiedeana Klotzsch & & \\
\hline Quercus rugosa Née & & & Heliconia wagneriana Petersen & & \\
\hline Quercus salicifolia Née & & & HERNANDIACEAE & & \\
\hline Quercus sapotifolia Liebm. & & & Gyrocarpus americanus Jacq. & & \\
\hline Quercus sartorii Liebm. & & & Hernandia sonora L. & & \\
\hline
\end{tabular}


Appendix 1. Continuation.

\begin{tabular}{|c|c|c|c|c|c|}
\hline SCIENTIFIC NAME & CITES & NOM- 059 & SCIENTIFIC NAME & CITES & NOM- 059 \\
\hline Hernandia wendtii Espejo & & & JUNCACEAE & & \\
\hline HYDRANGEACEAE & & & luncus effusus $\mathrm{L}$. & & \\
\hline Hydrangea hortensis Sm. & & & Luzula caricina E. Mey. & & \\
\hline Hydrangea macrophylla (Thunb.) Ser. & & & LACISTEMATACEAE & & \\
\hline $\begin{array}{l}\text { Hydrangea nebulicola Nevling \& } \\
\text { Gómez Pompa }\end{array}$ & & $\diamond$ & $\begin{array}{l}\text { Lacistema aggregatum (P.J. Bergius) Rusby } \\
\text { LAMIACEAE }\end{array}$ & & \\
\hline Philadelphus affinis Schltdl. & & & Aegiphila deppeana Steud. & & \\
\hline Philadelphus mexicanus Schltdl. & & & Agastache mexicana (Kunth) H.P. & & \\
\hline Philadelphus pueblanus S.Y. Hu & & & Kelsey \& Dayton & & \\
\hline HYMENOPHYLLACEAE & & & Agastache palmeri (B.L. Rob.) Standl. & & \\
\hline Hymenophyllum fucoides Sw. & & & Asterohyptis mociniana (Benth.) Epling & & \\
\hline Hymenophyllum hirsutum (L.) Sw. & & & Asterohyptis stellulata (Benth.) Epling & & \\
\hline Hymenophyllum polyanthos (Sw.) Sw. & & & Clerodendrum bungei Steud. & & \\
\hline Hymenophyllum trapezoidale Liebm. & & & Clerodendrum japonicum (Thunb.) & & \\
\hline Hymenophyllum tunbridgense (L.) Sm. & & & Sweet & & \\
\hline Trichomanes bucinatum Mickel \& Beitel & & & Clerodendrum ligustrinum R. Br. & & \\
\hline Trichomanes capillaceum L. & & & Clerodendrum philippinum Schauer & & \\
\hline Trichomanes collariatum Bosch & & & Clerodendrum thomsoniae Balf. & & \\
\hline Trichomanes crispum L. & & & Clinopodium brownei (Sw.) Kuntze & & \\
\hline Trichomanes hymenophylloides Bosch & & & Cornutia pyramidata L. & & \\
\hline Trichomanes krausii Hook. \& Grev. & & & Cunila Iythrifolia Benth. & & \\
\hline Trichomanes radicans Sw. & & & Cunila polyantha Benth. & & \\
\hline Trichomanes reptans Sw. & & & Hedeoma piperita Benth. & & \\
\hline HYPERICACEAE & & & Hyptis albida Kunth & & \\
\hline Ascyrum hypericoides L. & & & Hyptis atrorubens Poit. & & \\
\hline Hypericum formosum Kunth & & & Hyptis capitata Jacq. & & \\
\hline Hypericum hypericoides (L.) Crantz & & & Hyptis pectinata Poit. & & \\
\hline Hypericum oaxacanum R. Keller ex N. & & & Hyptis suaveolens (L.) Poit. & & \\
\hline Robson subsp. veracrucense N. Robson & & & Hyptis urticoides Kunth & & \\
\hline Hypericum pratense Cham. \&Schltdl. & & & Leonurus japonicus Houtt. & & \\
\hline Hypericum silenoides Juss. & & & Lepechinia caulescens (Ortega) Epling & & \\
\hline Hypericum simulans Rose & & & Lepechinia schiedeana Vatke & & \\
\hline HYPOXIDACEAE & & & Marrubium vulgare $\mathrm{L}$. & & \\
\hline Hypoxis decumbens L. & & & Marsypianthes chamaedrys (Vahl) & & \\
\hline IRIDACEAE & & & Kuntze & & \\
\hline Alophia veracruzana Goldblatt \& & & & Melissa officinalis L. & & \\
\hline T.M. Howard & & & Mentha spicata L. & & \\
\hline Eeutherine latifolia (StandI. \& L.O. & & & Monarda malloryi Gilly & & \\
\hline Williams) Ravenna & & & Ocimum basilicum $\mathrm{L}$. & & \\
\hline Neomarica gracilis Sprague & & & Ocimum carnosum (Spreng.) Link \& & & \\
\hline Neomarica variegata (M. Martens \& & & & Otto ex Benth & & \\
\hline Galeotti) Henrich \& Goldblatt & & & Origanum vulgare L. & & \\
\hline Orthrosanthus exsertus (R.C. Foster) & & & Pogostemon cablin Benth. & & \\
\hline Ravenna & & & Prunella vulgaris L. & & \\
\hline Sisyrinchium angustifolium Mill. & & & Rosmarinus officinalis L. & & \\
\hline Sisyrinchium convolutum Nocca & & & Salvia albiflora M. Martens \& Galeotti & & \\
\hline Sisyrinchium micranthum Cav. & & & Salvia arthrocoma Fernald & & \\
\hline Sisyrinchium scabrum Schltdl. \& Cham & & & Salvia biserrata M. Martens \& Galeotti & & \\
\hline Sisyrinchium schaffneri S. Watson & & & Salvia carnea Kunth & & \\
\hline Sisyrinchium tinctorium Kunth & & & Salvia chazaroana B.L. Turner & & \\
\hline Tigridia pavonia (L. f.) DC. & & & Salvia coccinea Buc'hoz ex Etl. & & \\
\hline Tritonia $\times$ crocosmiiflora G. Nicholson & & & Salvia elegans Vahl & & \\
\hline JUGLANDACEAE & & & Salvia hispanica L. & & \\
\hline Carya ovata (Mill.) K. Koch var. mexicana & & & Salvia involucrata Cav. & & \\
\hline (Engelm. Ex Hemsl.) W.E. Manning & & & Salvia lasiocephala Hook. \& Arn. & & \\
\hline Mglans pyriformis Liebm. & & $\diamond$ & Salvia lavanduloides Kunth & & \\
\hline & & & Salvia leucantha Cav. & & \\
\hline
\end{tabular}


Appendix 1. Continuation.

\begin{tabular}{|c|c|c|c|c|c|}
\hline SCIENTIFIC NAME & CITES & NOM- 059 & SCIENTIFIC NAME & CITES & NOM- 059 \\
\hline Salvia Iongispicata M. Martens \& Galeotti & & & Nectandra salicifolia Kunth & & \\
\hline Salvia microphylla Kunth & & & Nectandra sanguinea Rol. & & \\
\hline Salvia misella Kunth & & & Ocotea acuminatissima (Lundell) Rohwer & & \\
\hline Salvia mocinoi Benth. & & & Ocotea dendrodaphne Mez & & \\
\hline Salvia nana Kunth & & & Ocotea helicterifolia (Meisn.) Hemsl. & & \\
\hline Salvia occidentalis Sw. & & & Ocotea heydeana (Mez \& Donn. Sm.) & & \\
\hline Salvia polystachia Cav. & & & Bernardi & & \\
\hline Salvia protracta Benth. & & & Ocotea klotzschiana (Nees) Hemsl. & & \\
\hline Salvia purpurea Cav. & & & Ocotea psychotrioides Kunth & & \\
\hline Salvia recurva Benth. & & & Ocotea uxpanapana T. Wendt \& van & & \\
\hline Salvia rubiginosa Benth. & & & der Werff & & \\
\hline Salvia splendens ex Wied-Neuw & & & Persea americana Mill. & & \\
\hline Salvia thyrsiflora Benth. & & & Persea chamissonis Mez & & \\
\hline Salvia tiliifolia Vahl & & & Persea cinerascens S.F. Blake & & \\
\hline Salvia xalapensis Benth. & & & Persea donnell-smithii Mez & & \\
\hline Salvia zacuapanensis Briq. & & & Persea liebmannii Mez & & \\
\hline Scutellaria dumetorum Schltdl. & & & Persea longipes Meisn. & & \\
\hline Scutellaria racemosa Pers. & & & Persea schiedeana Nees & & \\
\hline Scutellaria seleriana Loes. & & & Persea standleyi C.K. Allen & & \\
\hline Scutellaria splendens Link, Klotzsch & & & LEMNACEAE & & \\
\hline \& Otto & & & Lemna minor L. & & \\
\hline Stachys agraria Schltdl. \& Cham. & & & LENTIBULARIACEAE & & \\
\hline Stachys biflora Hook \& Arn. & & & Pinguicula emarginata Zamudio \& Rzed. & & \\
\hline Stachys boraginoides Schltdl. \& Cham. & & & Pinguicula macrophylla Kunth & & \\
\hline Stachys coccinea Ortega & & & Pinguicula moranensis Kunth & & \\
\hline Stachys nepetifolia Desf. & & & LILIACEAE & & \\
\hline Stachys pringlei Greenm. & & & Lilium candidum L. & & \\
\hline Stachys radicans Epling & & & LINACEAE & & \\
\hline Stachys rotundifolia Moc. \& Sessé & & & Linum orizabae Planch. & & \\
\hline Teucrium vesicarium Mill. & & & Linum tenellum Cham.\& Schltdl. & & \\
\hline LAURACEAE & & & LINDSAEACEAE & & \\
\hline Beilschmiedia anay (S.F. Blake) Kosterm. & & & Lonchitis hirsuta L. & & \\
\hline Beilschmiedia mexicana (Mez) Kosterm. & & & Odontosoria schlechtendalii (Pr.) C. Chr. & & \\
\hline Cassytha filiformis L. & & & LOASACEAE & & \\
\hline $\begin{array}{l}\text { Cinnamomum amplexicaule (Cham. } \\
\text { \& Schltdl.) Kosterm. }\end{array}$ & & & $\begin{array}{l}\text { Eucnide hirta (Pav. ex G. Don) H.J. } \\
\text { Thomps. \& W.R. Ernst }\end{array}$ & & \\
\hline Cinnamomum effusum (Meisn.) Kosterm. & & & Gronovia scandens L. & & \\
\hline Cinnamomum leptophyllum Lorea-Hern. & & & Loasa triphylla Juss & & \\
\hline Cinnamomum pachypodum (Nees) & & & Mentzelia hispida Willd. & & \\
\hline Kosterm. & & & LOGANIACEAE & & \\
\hline Cinnamomum padiforme (Standl. \& & & & Spigelia anthelmia L. & & \\
\hline Steyerm.) Kosterm. & & & Soigelia scabra Cham. \& Schltdl. & & \\
\hline Cinnamomum triplinerve (Ruiz \& Pav.) & & & LORANTHACEAE & & \\
\hline Kosterm. & & & Psittacanthus schiedeanus Blume & & \\
\hline Cinnamomum zeylanicum Blume & & & Stuthanthus crassipes Eichler & & \\
\hline Licaria capitata (Cham. \& Schltdl.) & & & Struthanthus deppeanus Blume & & \\
\hline Kosterm. & & & Struthanthus marginatus Blume & & \\
\hline Licaria misantlae (Brandegee) Kosterm. & & & Struthanthus quercicola Blume & & \\
\hline Licaria peckii (I.M. Johnst.) Kosterm. & & & LYCOPODIACEAE & & \\
\hline Litsea glaucescens Kunth & & $\diamond$ & Huperzia dichotoma (Jacq.) Trevis. & & $\diamond$ \\
\hline Litsea neesiana (S. Schauer) Hemsl. & & & Huperzia linifolia (L.) Trevis & & \\
\hline $\begin{array}{l}\text { Nectandra ambigens (S.F. Blake) C.K. } \\
\text { Allen }\end{array}$ & & & $\begin{array}{l}\text { Huperzia pithyoides (Schltdl. \& Cham.) } \\
\text { Holub }\end{array}$ & & \\
\hline Nectandra coriacea Griseb. & & & Huperzia reflexa (Lam.) Trevis. & & \\
\hline Nectandra Iundellii C.K. Allen . & & & Huperzia taxifolia (Sw.) Trevis & & \\
\hline Nectandra membranacea (Sw.) Griseb & & & Lycopodiella cernua (L.) Pic. Serm. & & \\
\hline
\end{tabular}


Appendix 1. Continuation.

\begin{tabular}{|c|c|c|c|c|c|}
\hline SCIENTIFIC NAME & CITES & NOM- 059 & SCIENTIFIC NAME & CITES & NOM- 059 \\
\hline Lycopodium cernuum L. & & & Sweet Abutilon vexillarium $\mathrm{E}$. & & \\
\hline Lycopodium clavatum L. & & & Morren Anoda acerifolia Cav. & & \\
\hline Lycopodium thyoides Willd. & & & Anoda cristata (L.) Schltdl. & & \\
\hline LYGODIACEAE & & & Ayenia micrantha Standl. & & \\
\hline Lygodium venustum Sw. & & & Ayenia purpusii Brandegee & & \\
\hline LYTHRACEAE & & & Bakeridesia ferruginea (Martyn) Krapov. & & \\
\hline Adenaria floribunda Kunth & & & Bastardia viscosa (L.) Kunth & & \\
\hline Cuphea aequipetala Cav. & & & Belotia mexicana K. Schum. & & \\
\hline Cuphea calaminthifolia Schltdl. & & & Byttneria catalpifolia Jacq. & & \\
\hline Cuphea carthagenensis (Jacq.) J.F. Macbr. & & & Carpodiptera ameliae Lundell & & \\
\hline Cuphea cyanea DC. & & & Ceiba aesculifolia (Kunth) Britten \& & & \\
\hline Cuphea decandra W.T. Aiton & & & Baker f. & & \\
\hline Cuphea hyssopifolia Griseb. & & & Corchorus hirtus L. & & \\
\hline Cuphea micropetala Baill. & & & Corchorus orinocensis Kunth & & \\
\hline Cuphea nitidula Kunth & & & Corchorus siliquosus L. & & \\
\hline Cuphea pinetorum Benth. & & & Corchorus tridens L. & & \\
\hline Cuphea procumbens Ortega & & & Dombeya $\times$ cayeuxii André & & \\
\hline Cuphea racemosa (L. f.) Spreng. & & & Fuertesimalva limensis (L.) Fryxell & & \\
\hline Cuphea salicifolia Cham. \& Schltdl. & & & Guazuma ulmifolia Lam. & & \\
\hline Cuphea utriculosa Koehne & & & Hampea integerrima Schltdl. & & \\
\hline Cuphea wrightii A. Gray & & & Hampea nutricia Fryxell & & \\
\hline Lagerstroemia indica L. & & & Hampea rovirosae Standl. & & \\
\hline Lawsonia inermis L. & & & Heliocarpus americanus $\mathrm{L}$. & & \\
\hline Lythrum acinifolium ex DC. & & & Heliocarpus appendiculatus Turcz. & & \\
\hline Nesaea salicifolia Kunth & & & Heliocarpus mexicanus Sprague & & \\
\hline MAGNOLIACEAE & & & Heliocarpus pallidus Rose & & \\
\hline Magnolia grandiflora L. & & & Herissantia crispa Medik. & & \\
\hline Magnolia schiedeana Schlecht. & & $\diamond$ & Hibiscus acetosella Welw. ex Fic. & & \\
\hline Talauma mexicana G. Don & & & Hibiscus bifurcatus Cav. & & \\
\hline MALPIGHIACEAE & & & Hibiscus costatus A. Rich. & & \\
\hline Banisteria beecheyana (A. Juss.) C.B. & & & Hibiscus phoeniceus Jacq. & & \\
\hline Rob. & & & Hibiscus rosa-sinensis L.f. var. & & \\
\hline Bunchosia lindeniana A. Juss. & & & schizopetalus Mast. & & \\
\hline Bunchosia palmeri S. Watson & & & Hibiscus sabdariffa L. & & \\
\hline Bunchosia swartziana Griseb. & & & Hibiscus spiralis Cav. & & $\diamond$ \\
\hline Byrsonima crassifolia Steud & & & Hibiscus tiliaceus L. & & \\
\hline Callaeum malpighioides (Turcz.) & & & Hibiscus uncinellus ex DC. & & \\
\hline D.M. Johnson & & & Hochreutinera amplexifolia (DC.) & & \\
\hline Galphimia glauca Cav. & & & Fryxell & & \\
\hline Gaudichaudia albida Cham. \& Schltdl. & & & Kearnemalvastrum lacteum (Aiton) & & \\
\hline Heteropterys brachiata Kunth & & & D.M.Bates & & \\
\hline Malpighia glabra L. & & & Kosteletzkya tubiflora (DC.) O.J. & & \\
\hline Mascagnia vacciniifolia Nied. & & & Blanch. \& McVaugh & & \\
\hline Psychopterys polycarpa (Brandegee) & & & Luehea candida Mart. & & \\
\hline W.R. Anderson \& S. Corso & & & Luehea speciosa Willd. & & \\
\hline Stigmaphyllon bannisteroides(L.) & & & Malachra capitata L. & & \\
\hline C.E. Anderson & & & Malva parviflora L. & & \\
\hline Stigmaphyllon lindenianum A. Juss. & & & Malvastrum coromandelianum (L.) & & \\
\hline MALVACEAE & & & Garcke & & \\
\hline Abelmoschus manihot (L.) Medik. & & & Malvastrum spicatum A. Gray & & \\
\hline Abelmoschus moschatus Medik. & & & Malvaviscus arboreus Cav. & & \\
\hline Abutilon hulseanum (Torr. \& A. Gray) & & & Melochia bernoulliana Donn. Sm. & & \\
\hline Torr. ex A. Gray & & & Melochia pyramidata L. & & \\
\hline Abutilon hypoleucum A. Gray & & & Melochia tomentosa L. & & \\
\hline Abutilon purpusii Standl. & & & Modiola caroliniana (L.) G. Don & & \\
\hline Abutilon subsagittatum Hochr. & & & Mortoniodendron guatemalense Standl. & & $\diamond$ \\
\hline Abutilon umbellatum (L.) & & & \& Steyerm. & & \\
\hline
\end{tabular}


Appendix 1. Continuation.

\begin{tabular}{|c|c|c|c|c|c|}
\hline SCIENTIFIC NAME & CITES & NOM- 059 & SCIENTIFIC NAME & CITES & NOM- 059 \\
\hline Mortoniodendron sulcatum Lundell & & & Conostegia caelestis Standl. & & \\
\hline Pachira aquatica Aubl. & & & Conostegia icosandra Urb. & & \\
\hline Pavonia fruticosa (Mill.) Fawc. \& Rendle & & & Conostegia superba D. Don & & \\
\hline Pavonia multifllora A. St.-Hil. & & & Conostegia volcanalis Standl. \& Steyerm. & & \\
\hline Pavonia paniculata Cav. & & & Conostegia xalapensis D. Don & & \\
\hline Pavonia rosea Schltdl. & & & Heterocentron elegans Kuntze & & \\
\hline Pavonia schiedeana Steud. & & & Heterocentron subtriplinervium A. & & \\
\hline Pavonia spinifex (L.) Cav. & & & Braun \& Bouché & & \\
\hline Pavonia uniflora (Sessé \& Moc.) Fryxell & & & Leandra melanodesma Cogn. & & \\
\hline Phymosia umbellata (Cav.) Kearney & & & Leandra mexicana Cogn. & & \\
\hline Pseudabutilon scabrum (C. Presl) R.E.Fr. & & & Leandra subseriata Cogn. & & \\
\hline Robinsonella mirandae Gómez Pompa & & & Miconia affinis DC. & & \\
\hline Robinsonella pilosa Rose & & & Miconia anisotricha Triana & & \\
\hline Sida acuta Burm. F. & & & Miconia chrysoneura Triana & & \\
\hline Sida cordifolia L. & & & Miconia dodecandra Cogn. & & \\
\hline Sida glabra Mill. & & & Miconia glaberrima Naudin & & \\
\hline Sida rhombifolia L. & & & Miconia ibaguensis C. Wright & & \\
\hline Sida spinosa L. & & & Miconia impetiolaris(Sw.) D. Don ex DC. & & \\
\hline Sida urens L. & & & Miconia lacera (Bonpl.) Naudin & & \\
\hline Sidastrum paniculatum (L.) Fryxell & & & Miconia laevigata (L.) D. Don & & \\
\hline Talipariti tiliaceum var. pernambucense & & & Miconia mexicana Naudin & & \\
\hline (Arruda) Fryxell & & & Miconia moorei Wurdack & & \\
\hline Theobroma cacao L. & & & Miconia oligotricha Naudin & & \\
\hline Tilia mexicana Schltdl. & & & Miconia sylvatica Schltdl. & & \\
\hline Tilia neglecta Spach & & & Miconia trinervia (Sw.) D. Don ex Loudon & & \\
\hline Trichospermum galeottii (Turcz) Kosterm. & & & Monochaetum calcaratum Triana & & \\
\hline Triumfetta bogotensis DC. & & & Monochaetum deppeanum Naudin & & \\
\hline Triumfetta columnaris Hochr. & & & Monochaetum floribundum Naudin & & \\
\hline Triumfetta grandiflora Vahl & & & Mouriri myrtilloides Poir. & & \\
\hline Triumfetta lappula Schomb. & & & Tibouchina galeottiana (Naudin) Cogn. & & \\
\hline Triumfetta orizabae Turcz. & & & Tibouchina Iongifolia Baill. & & \\
\hline Triumfetta semitriloba Jacq. & & & Tibouchina longisepala Cogn. & & \\
\hline Waltheria indica L. & & & Tibouchina mexicana Cogn. & & \\
\hline Wissadula hernandioides (L'Hér.) Garcke & & & Tibouchina naudiniana Cogn. & & \\
\hline Wissadula periplocifolia (L.) Thwaites & & & Tibouchina purpusii Brandegee & & \\
\hline MARANTACEAE & & & Tibouchina rufipilis Cogn. & & \\
\hline Goeppertia misantlensis (Lascur.) & & & Tibouchina schiedeana Cogn. & & \\
\hline Borchs. \& S. Suárez & & & Tibouchina urvilleana Cogn. & & \\
\hline Maranta arundinacea L. & & & Topobea laevigata (D. Don) Naudin & & \\
\hline Maranta gibba Sm. & & & Triolena scorpioides Naudin & & \\
\hline Monotagma laxum (Poepp. \& Endl.) & & & MELIACEAE & & \\
\hline K. Schum. & & & Cedrela odorata L. & & $\diamond$ \\
\hline MARATTIACEAE & & & Guarea glabra Vahl & & \\
\hline Marattia weinmanniifolia Liebm. & & $\diamond$ & Guarea grandifolia DC. & & \\
\hline MARCGRAVIACEAE & & & Guarea tuerckheimii C.DC. ex Donn.Sm. & & \\
\hline Marcgravia mexicana Gilg & & & Trichilia elegans A. Juss. & & \\
\hline Souroubea exauriculata Delp. & & & Trichilia glabra L. & & \\
\hline MELASTOMATACEAE & & & Trichilia havanensis Jacq. & & \\
\hline Arthrostemma ciliatum Pav. ex D. Don & & & Trichilia japurensis C. DC. & & \\
\hline Centradenia grandifolia (Schltdl.) Endl. & & & Trichilia martiana C. DC. & & \\
\hline Centradenia inaequilateralis G. Don & & & Trichilia moschata Sw. & & \\
\hline Clidemia dentata D. Don & & & Trichilia pallida Sw. & & \\
\hline Clidemia hirta D. Don & & & MENISPERMACEAE & & \\
\hline Clidemia laxiflora Schltdl. & & & Cissampelos fasciculata Benth. & & \\
\hline Clidemia petiolaris Triana & & & Cissampelos pareira L. & & \\
\hline Clidemia setosa (Triana) Gleason & & & Hyperbaena mexicana Miers & & \\
\hline Conostegia arborea Schltdl. ex Steud. & & & Odontocarya mexicana Barneby & & \\
\hline
\end{tabular}


Appendix 1. Continuation.

\begin{tabular}{|c|c|c|c|c|c|}
\hline SCIENTIFIC NAME & CITES & NOM- 059 & SCIENTIFIC NAME & CITES & NOM- 059 \\
\hline METTENIUSACEAE & & & Eugenia colipensis O. Berg & & \\
\hline Calatola costaricensis Standl. & & & Eugenia hypargyrea Standl. & & \\
\hline Calatola mollis Standl. & & & Eugenia mexicana Steud. & & \\
\hline Oecopetalum mexicanum Greenm. \& & & & Eugenia mozomboensis P.E. Sánchez & & \\
\hline C.H. Thomps. & & & Eugenia oerstediana O. Berg & & \\
\hline MONIMIACEAE & & & Eugenia pueblana Lundell & & \\
\hline Mollinedia viridiflora Tul. & & & Eugenia trunciflora (Schltdl. \& & & \\
\hline Siparuna thecaphora A. DC. & & & Cham.) G.Don & & \\
\hline MONTIACEAE & & & Eugenia venezuelensis O. Berg & & \\
\hline Calandrinia ciliata DC. & & & Eugenia xalapensis DC. & & \\
\hline MORACEAE & & & Eugenia yautepecana Lundell & & \\
\hline Bagassa guianensis Aubl. & & & Myrcianthes fragrans (Sw.) McVaugh & & \\
\hline Brosimum alicastrum Sw. & & & Pimenta dioica (L.) Merr. & & \\
\hline Castilla elastica Cerv. & & & Psidium guineense Sw. & & \\
\hline Dorstenia contrajerva L. & & & Syzygium jambos (L.) Alston & & \\
\hline Ficus americana Aubl. & & & NYCTAGINACEAE & & \\
\hline Ficus apollinaris Dugand & & & Boerhavia diffusa L. & & \\
\hline Ficus aurea Nutt. & & & Boerhavia erecta L. & & \\
\hline Ficus costaricana Miq. & & & Bougainvillea glabra Choisy & & \\
\hline Ficus crocata Mart. ex Miq. & & & Bougainvillea spectabilis Willd. & & \\
\hline Ficus fuscescens Miq. & & & Mirabilis jalapa L. & & \\
\hline Ficus glycicarpa Miq. & & & Neea tenuis Standl. & & \\
\hline Ficus insipida Willd. & & & NYSSACEAE & & \\
\hline Ficus lapathifolia Miq. & & & Nyssa sylvatica Marshall & & \\
\hline Ficus maxima Mill. & & & OCHNACEAE & & \\
\hline Ficus microcarpa L.f. & & & Ouratea nitida Engl. & & \\
\hline Ficus obtusifolia Kunth & & & Sauvagesia erecta L. & & \\
\hline Ficuspertusa L.f. & & & OLEACEAE & & \\
\hline Ficus trigonata L. & & & Fraxinus dubia (Willd.) P.S. Green & & \\
\hline Ficusturrialbana W.C. Burger & & & $\&$ M. Nee & & \\
\hline Ficus velutina Humb. \& Bonpl. ex Willd. & & & Fraxinus greggii A. Gray & & \\
\hline Ficus yoponensis Desv. & & & asminum gracillimum Hook. f. & & \\
\hline Maclura tinctoria(L.) D. Don ex Steud. & & & asminum grandiflorum $\mathrm{L}$. & & \\
\hline Morus alba L. & & & Jasminum mesnyi Hance & & \\
\hline $\begin{array}{l}\text { Pseudolmedia glabrata (Liebm.) } \\
\text { C.C. Berg. }\end{array}$ & & & $\begin{array}{l}\text { Osmanthus americanus Benth. } \\
\text { \& Hook. f. }\end{array}$ & & \\
\hline Trophis mexicana (Liebm.) Bureau & & & ONAGRACEAE & & \\
\hline Trophis racemosa (L.) Urb. & & & Epilobium ciliatum Raf. & & \\
\hline MUNTINGIACEAE & & & Fuchsia arborescens Sims & & \\
\hline Muntingia calabura L. & & & Fuchsia boliviana Carrière & & \\
\hline MUSACEAE & & & Fuchsia microphylla Kunth & & \\
\hline Musa balbisiana Colla & & & Fuchsia paniculata Lindl. & & \\
\hline Musa paradisiaca L. & & & Fuchsia thymifolia Kunth & & \\
\hline Musa ornata Roxb. & & & Gongylocarpus rubricaulis Cham. & & \\
\hline MYRICACEAE & & & \& Schltdl. & & \\
\hline Myrica cerifera L. & & & Lopezia miniata DC. & & \\
\hline MYRTACEAE & & & Lopezia racemosa Cav. & & \\
\hline Calycorectes mexicanus O. Berg & & & Ludwigia octovalvis (Jacq.) P.H. Raven & & \\
\hline Calyptranthes chytraculia Sw. & & & Ludwigia palustris(L.) Elliott & & \\
\hline Calyptranthes karlingii Standl. & & & Ludwigia peruviana (L.) H. Hara & & \\
\hline Calyptranthes karwinskyana O. Berg & & & Oenothera kunthiana (Spach) Munz & & \\
\hline Calyptranthes schiedeana O. Berg & & & Oenothera rosea Aiton & & \\
\hline Calyptranthes schlechtendaliana O. Berg & & & OPHIOGLOSSACEAE & & \\
\hline Calyptranthes tenuipes McVaugh & & & Botrychium virginianum (L.) Sw. & & \\
\hline Eucalyptus globulus Labill. & & & OPILIACEAE & & \\
\hline $\begin{array}{l}\text { Eugenia acapulcensis Steud. } \\
\text { Eugenia capuli Schltdl. }\end{array}$ & & & Agonandra racemosa Standl. & & \\
\hline
\end{tabular}


Appendix 1. Continuation.

\begin{tabular}{ll}
\hline SCIENTIFIC NAME & CITES NOI N \\
\hline ORCHIDACEAE & \\
Acianthera angustifolia (Lindl.) Luer & Appendix II \\
Acianthera circumplexa(Lindl.) & Appendix II \\
$\quad$ Pridgeon \& M.W. Chase & \\
Acianthera obscura (A. Rich. \& Galeotti) & Appendix II \\
$\quad$ Pridgeon \& M.W. Chase & \\
Arpophyllum giganteum Hartw. ex Lindl. & Appendix II \\
Arpophyllum laxiflorum Pfitzer & Appendix II \\
Arpophyllum spicatum Lex. & Appendix II \\
Beloglottis costaricensis Schltr. & Appendix II \\
Beloglottis mexicana Garay \& Hamer & Appendix II \\
Bletia gracilis G. Lodd. & Appendix II \\
Bletia purpurata A. Rich. \& Galeotti & Appendix II \\
Brassavola appendiculata A. Rich. \& & Appendix II \\
Galeotti &
\end{tabular}

Brassavola cucullata R. Br.

Brassia verrucosa Lindl.

Bulbophyllum pachyrhachis (A.Rich.)

Griseb

Calanthe calanthoides (A. Rich. \&

Galeotti) Hamer \& Garay

Camaridium densum (Lindl.) M.A. Blanco Appendix II

Catasetum integerrimum Hook. Appendix II

Chysis $\times$ laevis Lindl.

Coelia macrostachya Lindl.

Coelia triptera (Sm.) Steud.

Corallorhiza bulbosa A. Rich. \& Galeotti

Corymborkis forcipigera (Rchb. f. \&

Warsz.) L.O. Williams

Cranichis sylvatica A. Rich. \& Galeotti

Cyclopogon comosus (Rchb. f.)

Burns-Bal. \& E.W. Greenw.

Cyclopogon saccatus (A. Rich. \&

Galeotti) Schltr.

Cyrtopodium punctatum (L.) Lindl.

Dichaea graminoides Lindl.

Dichaea muricatoides Hamer \& Garay

Dichaea neglecta Schltr.

Domingoa purpurea (Lindl.) Van den

Berg \& Soto Arenas

Bleanthus cynarocephalus Rchb. $f$.

Encyclia alata (Bateman) Schltr.

Encyclia livida (Lindl.) Dressler

Encyclia ochracea (Lindl.) Dressler

Encyclia parviflora (Regel) Withner

Encyclia polybulbon (Sw.) Dressler

Epidendrum ciliare L.

Epidendrum cristatum Ruiz \& Pav.

Epidendrum difforme Jacq.

Epidendrum diffusum Sw.

Epidendrum longipetalum A. Rich.

\& Galeotti

Epidendrum melistagum Hágsater

Epidendrum nocturnum Jacq.

Epidendrum paniculatum Ruiz \& Pav.

Epidendrum parkinsonianum Hook.

Epidendrum polyanthum Lindl.
Appendix II

Appendix II

Appendix II

Appendix II

Appendix II

Appendix II

Appendix II

Appendix II

Appendix II

Appendix II

Appendix II

Appendix II

Appendix II Appendix II Appendix II Appendix II Appendix II

Appendix II Appendix II Appendix II Appendix II Appendix II Appendix II Appendix II Appendix II Appendix II Appendix II Appendix II

Appendix II Appendix II Appendix II Appendix II Appendix II
SCIENTIFIC NAME

CITES NOM- 059

Epidendrum propinquum A. Rich.

\& Galeotti

Epidendrum ramosum Jacq.

Epidendrum repens Cogn.

Epidendrum tuxtlense Hágsater,

García-Cruz \& L. Sánchez

Goodyera brachyceras (A. Rich. \&

Galeotti) Garay \& G.A. Romero

Goodyera striata Rchb. f.

Govenia liliacea (La Llave \& Lex.) Lindl.

Govenia mutica Rchb. f.

Govenia praecox Salazar \& E.W. Greenw.

Govenia praecox Salazar \& E.W. Greenw. Appendix II

Habenaria alata Hook.

Habenaria bractescens Lindl.

Habenaria distans Griseb

Habenaria entomantha (La Llave

\& Lex.) Lindl.

Habenaria floribunda Lindl.

Habenaria pringlei B.L. Rob.

Habenaria quinqueseta (Michx.) Sw.

lonopsis utricularioides Lindl.

Isochilus latibracteatus A. Rich. \& Galeotti

Isochilus linearis (Jacq.) R. Br.

Isochilus major var. amparoanus

(Schltr.) Correll

Isochilus unilateralis B.L. Rob.

acquiniella leucomelana Schltr.

acquiniella teretifolia (Sw.)

Britton \& P. Wilson

Laelia anceps Lindl.

Lepanthes avis Rchb. f.

Liparis vexillifera (La Llave \& Lex.) Cogn.

Lycaste aromatica Lindl.

Lycaste deppei (Lodd.) Lindl.

Malaxis excavata Kuntze

Malaxis fastigiata Kuntze

Malaxis histionantha (Link, Klotzsch \&

Otto) Garay \& Dunst.

Malaxis soulei L.O. Williams

Malaxis unifolia Michx.

Maxillaria cucullata Lindl.

Maxillaria variabilis Bateman ex Lindl.

Maxillariella tenuifolia (Lindl.) M.A.

Blanco \& Carnevalli

Mesadenus Iucayanus Schltr.

Myrmecophila tibicinis (Bateman) Rolfe

Nageliella purpurea(Lindl.) L.O. Williams Appendix II

Nidema boothii (Lindl.) Schltr.

Notylia barkeri Lindl.

Oncidium carthagenense (Jacq.) Sw.

Oncidium cavendishianum Bateman

Oncidium sphacelatum Lindl.

Oncidium stramineum Lindl.

Ornithocephalus gladiatus Hook.
Appendix II

Appendix II

Appendix II

Appendix II

Appendix II

Appendix II

Appendix II

Appendix II

Appendix II

Appendix II

Appendix II

Appendix II

Appendix II

Appendix II

Appendix II

Appendix II

Appendix II

Appendix II

Appendix II

Appendix II

Appendix II

Appendix II

Appendix II

Appendix II

Appendix II

Appendix II

Appendix II

Appendix II

Appendix II

Appendix II

Appendix II

Appendix II

Appendix II

Appendix II

Appendix II

Appendix II

Appendix II
Appendix II

Appendix II

Appendix II

Appendix II

Appendix II

Appendix II

Appendix II
Appendix II 
Appendix 1. Continuation.

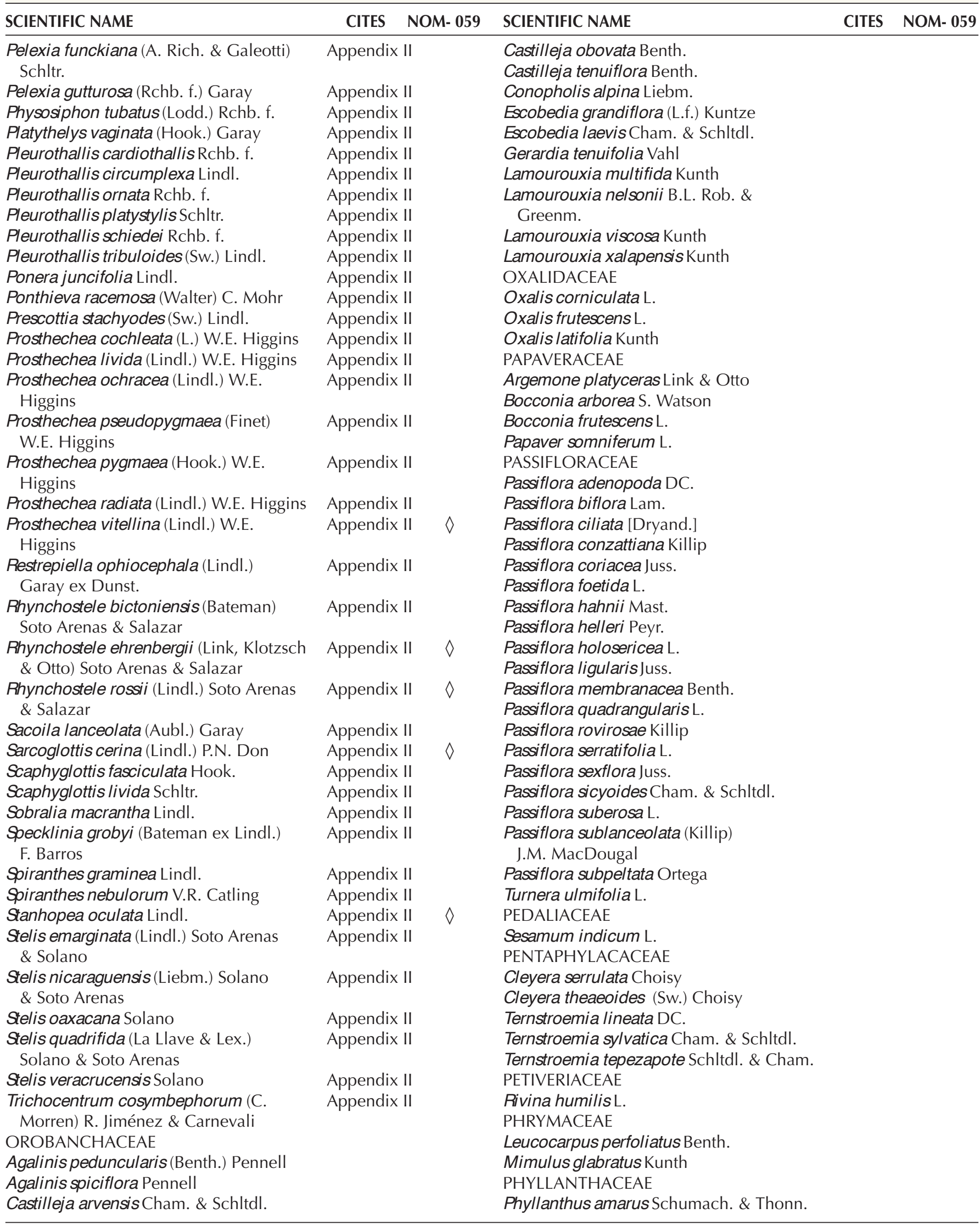


Appendix 1. Continuation.

SCIENTIFIC NAME

Phyllanthus compressus Kunth

Phyllanthus graveolens Kunth

Phyllanthus liebmannianus Müll.Arg.

Phyllanthus niruri L.

Phyllanthus stipulatus (Raf.) G.L. Webster

Savia sessiliflora Willd.

PHYTOLACCACEAE

Agdestis clematidea Moc. \& Sessé

Phytolacca americana $\mathrm{L}$.

Phytolacca icosandra L.

Phytolacca rivinoides Kunth \& C.D.

Bouché

PICRAMNIACEAE

Picramnia antidesma subsp. fessonia

(DC.) W.W. Thomas

Picramnia xalapensis Planch.

PINACEAE

Pinus chiapensis (Martínez) Andresen

Pinus leiophylla Schltdl. \& Cham.

Pinus montezumae Lamb.

Pinus nubicola J.P. Perry

Pinus patula Schltdl. \& Cham.

Pinus pseudostrobus Lindl.

Pinus strobus var. chiapensis Martínez

Pinus teocote Schltdl. \& Cham.

PIPERACEAE

Peperomia alata Ruiz \& Pav.

Peperomia angularis C. DC.

Peperomia angustata Kunth

Peperomia arboricola C. DC.

Peperomia asarifolia Schltdl.

Peperomia berlandieri Miq.

Peperomia blanda (Jacq.) Kunth

Peperomia blanda var. humilis (Vahl.)

Callejas

Peperomia dendrophila Schltdl.

Peperomia deppeana Schltdl. \& Cham.

Peperomia donaguiana C. DC.

Peperomia emarginulata C. DC.

Peperomia epidendron C. DC.

Peperomia galioides Kunth

Peperomia glabella (Sw.) A. Dietr.

Peperomia granulosa Trel.

Peperomia hernandiifolia (Vahl) A. Dietr.

Peperomia liebmannii C. DC.

Peperomia macrostachyos (Vahl.) A.Dietr.

Peperomia maculosa (L.) Hook.

Peperomia oajacensis Dahlst.

Peperomia obtusifolia (L.) A. Dietr.

Peperomia petrophila C. DC.

Peperomia pseudoalpina Trel.

Peperomia quadrifolia (L.) Kunth

Peperomia rotundifolia (L.) Kunth

Peperomia santa-helenae Trel.

Peperomia subblanda C. DC.

Peperomia tenerrima Schltdl. \& Cham.
CITES NOM- 059 SCIENTIFIC NAME

CITES NOM- 059

Peperomia tetraphylla Hook. \& Arn.

Peperomia tuisana C. DC. ex Pittier

Piper aduncum L.

Piper aequale Vahl

Piper amalago L.

Piper auritum Kunth

Piper colipanum C. DC.

Piper dilatatum Rich.

Piper glabrescens C. DC.

Piper hispidum Sw.

Piper jalapense M. Martens \& Galeotti

Piper lapathifolium Steud.

Piper martensianum C. DC.

Piper melastomoides Schltdl. \& Cham.

Piper misantlense C. DC.

Piper pseudofuligineum C. DC.

Piper psilorhachis C. DC.

Piper sanctum Miq.

Piper schiedeanum Steud.

Piper umbellatum L.

Piper unguiculatum Ruiz \& Pav.

PLAGIOGYRIACEAE

Plagiogyria pectinata (Liebm.) Lellinger

PLANTAGINACEAE

$\checkmark \quad$ Bacopa monnieri (L.) Wettst.

Bacopa salzmannii (Benth.) Wettst. ex Edwall

Callitriche verna $\mathrm{L}$.

Cymbalaria muralis G. Gaertn., B.

Mey. \& Scherb.

Digitalis purpurea L.

Linaria canadensis Dum. Cours.

Lophospermum erubescens D. Don

Mecardonia procumbens (Mill.) Small

Penstemon hartwegii Benth.

Penstemon isophyllus B.L. Rob.

Plantago australis Lam.

Plantago lanceolata L.

Plantago major L.

Russelia coccinea (L.) Wettst.

Russelia equisetiformis Schltdl. \& Cham.

Russelia sarmentosa Jacq.

Schistophragma mexicanum Benth.

ex D. Dietr.

Sibthorpia repens (L.) Kuntze

Stemodia lanata Ruiz \& Pav. ex Benth.

Stemodia macrantha B.L. Rob.

Stemodia verticillata (Mill.) Hassl.

Tetranema roseum (M. Martens \&

Galeotti) Standl. \& Steyerm.

Veronica arvensis L.

Veronica peregrina L.

Veronica persica Poir.

PLATANACEAE

Platanus mexicana Moric.

PLUMBAGINACEAE

Plumbago auriculata Lam. 
Appendix 1. Continuation.

\section{SCIENTIFIC NAME}

Plumbago zeylanica L.

POACEAE

Aegopogon cenchroides Humb. \& Bonpl. ex Willd.

Aegopogon tenellus Trin. Agrostis bourgeaei E. Fourn. Agrostis perennans Tuck. Agrostis scabra Willd. Andropogon bicornis L. Andropogon cirratus Hack. Andropogon condensatus Kunth Andropogon glomeratus Britton, Sterns \& Poggenb Andropogon gyrans Ashe Andropogon liebmannii Hack. Andropogon littoralis Nash Andropogon microstachyus Ham. Andropogon salzmannii (Trin. ex

Steud.) Hack.

Andropogon scoparius Michx. Andropogon selloanus (Hack.) Hack. Andropogon virginicus L.

Aristida liebmannii E. Fourn ex Hemsl. Andropogon virginicus L.

Aristida purpurea Nutt.

Aristida schiedeana Trin. \& Rupr.

Aristida ternipes Cav.

Arundinella berteroniana Hitchc. \& Chase

Arundinella deppeana Nees

Arundinella hispida Kuntze

Avena sativa L.

Axonopus ater Chase

Axonopus compressus P. Beauv.

Bothriochloa saccharoides (Sw.) Rydb.

Botriochloa laguroides (DC.) Herter

Bouteloua curtipendula (Michx.) Torr.

Brachiaria plantaginea (Link) Hitchc.

Brachypodium mexicanum Link

Brachypodium pringlei Scribn. ex Beal

Briza minor L.

Briza rotundata Steud.

Bromus catharticus Vahl

Bromus secalinus L.

Bromus unioloides Kunth

Cenchrus brownii Roem. \& Schult.

Cenchrus echinatus L.

Chascolytrum subaristatum Desv.

Chloris gayana Kunth

Chloris virgata $\mathrm{Sw}$.

Chusquea enigmatica Ruiz-Sánchez,

Mejía-Saulés \& L.G.Clark

Chusquea glauca L.G. Clark

Chusquea mulleri Munro

Cryptochloa strictiflora (E. Fourn.) Swallen

Cymbopogon citratus Stapf

Cynodon plectostachyus (K. Schum.) Pilg.

\section{CITES NOM- 059 SCIENTIFIC NAME}

CITES NOM- 059

Dichanthelium acuminatum (Sw.) Gould

\& C.A. Clark

Dichanthelium commutatum (Schult.)

Gould

Dichanthelium dichotomum (Elliott) Gould \& C.A.Clark

Dichanthelium viscidellum (Scribn.) Gould

Dichanthelium aciculare (Desv. ex Poir.) Gould \& C.A. Clark

Dichanthelium boscii (Poir.) Gould \& C.A. Clark

Dichanthelium commutatum (Schult.) Gould

Dichanthelium Iaxiflorum (Lam.) Gould

Digitaria ciliaris (Retz.) Koeler

Digitaria eriantha Steud.

Digitaria insularis(L.) Fedde

Digitaria milanjiana (Rendle) Stapf

Digitaria sanguinalis (L.) Scop.

Digitaria villosa Michx.

Echinochloa cruz-galli (L.) P. Beauv.

Echinochloa crus-pavonis (Kunth) Schult.

Echinochloa pyramidalis (Lam.) Hitchc.

\& Chase

Bionurus tripsacoides Humb. \& Bonpl. ex Willd.

Eragrostis bahiensis Schrad.

Eragrostis intermedia Hitchc.

Eragrostis lugens Nees

Eragrostis pilosa P. Beauv.

Eragrostis tenuifolia Hochst.

Eriochloa punctata (L.) Desv. ex Ham.

Festuca arundinacea Schreb.

Guadua aculeata Rupr. ex E. Fourn.

Guadua amplexifolia J. Presl.

Guadua longifolia (E. Fourn.) R.W. Pohl

Guadua velutina Londoño \& L.G. Clark

Hemarthria altissima (Poir.) Stapf \&

C.E. Hubb.

Heteropogon contortus Beauv. ex Roem. \& Schult.

Homolepis aturensis Chase

Homolepis glutinosa (Sw. ex Smithson)

Zuloaga \& Soderstr.

Hordeum vulgare L.

Hymenachne amplexicaulis Nees

Hordeum vulgare L.

Ichnanthus nemorosus (Sw.) Döll

Ichnanthus pallens (Sw.) Benth.

Ichnanthus tenuis Hitchc. \& Chase

Isachne arundinacea Griseb.

Ixophorus unisetus Schltdl.

arava ichu Ruiz \& Pav.

Lasiacis divaricata (L.) Hitchc.

Lasiacis grisebachii Hitchc.

Lasiacis nigra Davidse 
Appendix 1. Continuation.

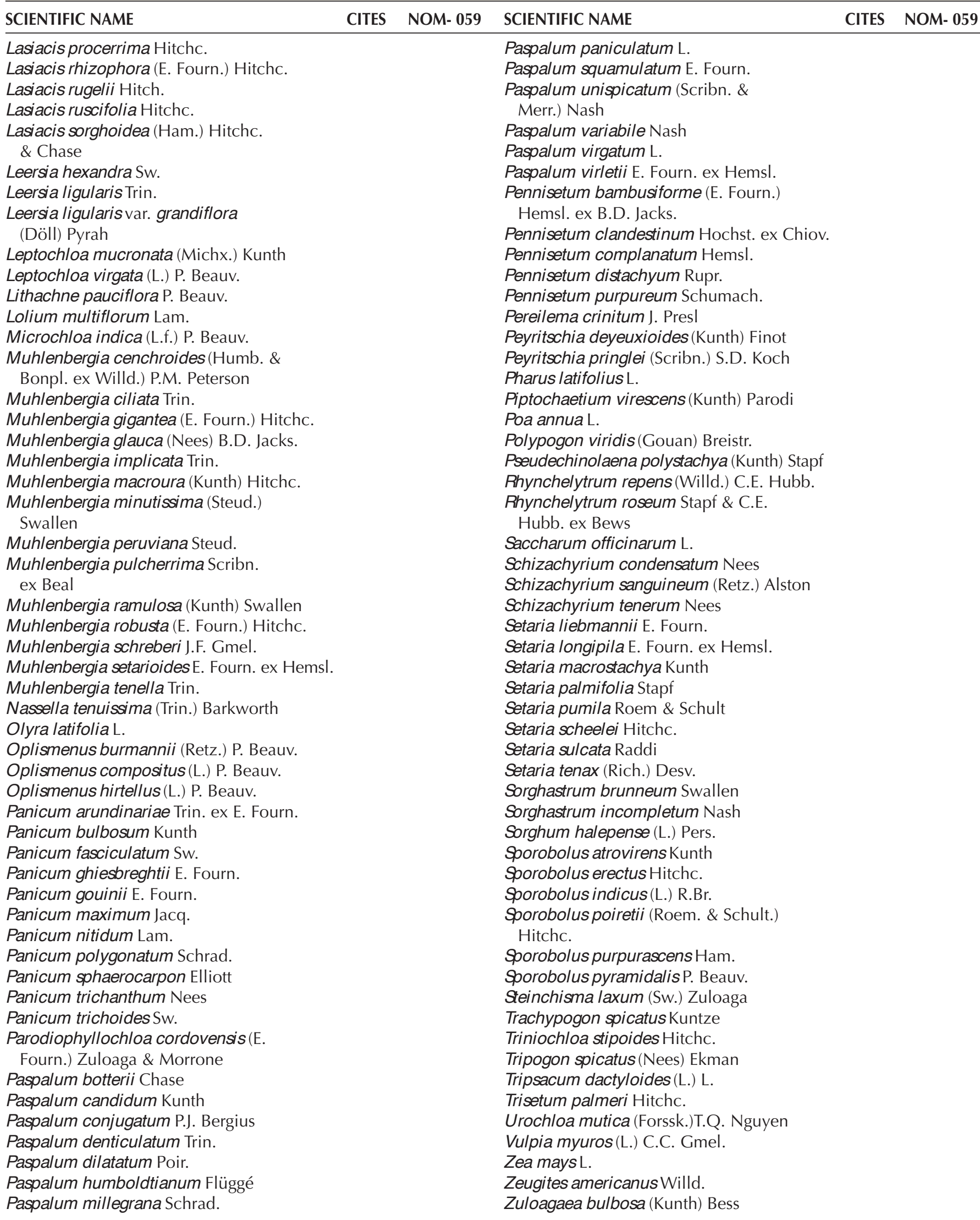


Appendix 1. Continuation.

\section{SCIENTIFIC NAME}

PODOCARPACEAE

Podocarpus guatemalensis Standl.

Podocarpus matudae Lundell

POLEMONIACEAE

Cobaea scandens Cav.

Loeselia ciliata L.

Loeselia glandulosa (Cav.) G. Don

Loeselia mexicana Brand

POLYGALACEAE

Hebecarpa rivinifolia (Kunth) J.r. Abbot

\& J.F.B. Pastore

Monnina schlechtendaliana D. Dietr.

Monnina xalapensis Kunth

Polygala alba Nutt.

Polygala berlandieri S. Watson

Polygala biformipilis S.F. Blake

Polygala glochidata Kunth

Polygala paniculata L.

Securidaca diversifolia (L.) S.F. Blake

Securidaca sylvestris Schltdl.

POLYGONACEAE

Antigonon cinerascens M. Martens

\& Galeotti

Antigonon flavescens S. Watson

Antigonon leptopus Hook. \& Arn.

Coccoloba belizensis Standl.

Coccoloba cozumelensis Hemsl.

Coccoloba escuintlensis Lundell

Coccoloba hirtella Lundell

Coccoloba humboldtii Meisn.

Coccoloba tuerckheimii Donn. Sm.

Homalocladium platycladum L.H. Bailey

Persicaria hydropiperoides Small

Persicaria segetum (Kunth) Small

Podopterus mexicanus Bonpl.

Polygonum punctatum Elliott

Rumex acetosella L.

Rumex crispus L.

Rumex obtusifolius L.

Rumex pulcher L.

POLYPODIACEAE

Campyloneurum angustifolium Fée

Campyloneurum xalapense Fée

Melpomene xiphopteroides (Liebm.)

A.R. Sm. \& R.C. Moran

Niphidium crassifolium (L.) Lellinger

Pecluma alfredii (Rosenst.) M.G. Price

Pecluma atra (A.M. Evans) M.G. Price

Pecluma dispersa (A.M. Evans)

M.G. Price

Pecluma plumula (Humb. \& Bonpl.

ex Willd.) M.G. Price

Phlebodium areolatum (Willd.) J. Sm.

Phlebodium aureum (L.) J.Sm.

Pleopeltis astrolepis (Liebm.) E. Fourn.

Pleopeltis crassinervata T. Moore
CITES NOM- 059 SCIENTIFIC NAME

CITES NOM- 059

Pleopeltis fallax (Schltdl. \& Cham.)

Mickel \& Beitel

$\diamond \quad$ Pleopeltis macrocarpa (Bory ex

Willd.) Kaulf.

Pleopeltis polylepis var. interjecta

(Weath.) E.A. Hooper

Polypodium conterminans Liebm.

Polypodium dissimile $\mathrm{L}$.

Polypodium eatonii Baker

Polypodium fraternum Schltdl. \& Cham.

Polypodium furfuraceum Schltdl. \& Cham.

Polypodium lepidotrichum (Fée) Maxon

Polypodium longepinnulatum Fourn.

Polypodium loriceum L.

Polypodium plebeium Schltdl. \& Cham.

Polypodium plesiosorum Kunze

Polypodium puberulum Schltdl. \& Cham.

Polypodium rhodopleuron Kunze

Polypodium subpetiolatum Hk.in Benth.

Polypodium thyssanolepis A. Br.; KI.

Polypodium triseriale Sw.

Polytrichum juniperinum Hedw.

PONTEDERIACEAE

Heteranthera reniformis Ruiz \& Pav.

POTAMOGETONACEAE

Zannichellia palustris L.

PRIMULACEAE

Amatlania jalapensis (Lundell) Lundell

Anagallis arvensis L.

Anagallis pumila Sw.

Ardisia revoluta Kunth

Ardisia compressa Kunth

Ardisia hyalina Lundell

Ardisia liebmannii Oerst.

Ardisia nigrescens Oerst.

Ardisia paniculata Roxb.

Ardisia pellucida Oerst.

Gentlea penduliflora (A. DC.) Pipoly

\& Ricketson

Myrsine coriacea R. Br.

Parathesis chiapensis Fernald

Parathesis donnell-smithii Mez

Parathesis lenticellata Lundell

Parathesis melanosticta Hemsl.

Parathesis psychotrioides Lundell

Parathesis serrulata (Sw.) Mez

Samolus parviflorus Kunth

PSILOTACEAE

Psilotum complanatum Sw.

Psilotum nudum (L.) P. Beauv.

PTERIDACEAE

Adiantopsis radiata (L.) Fée

Adiantum amplum C. Presl

Adiantum andicola Liebm.

Adiantum braunii Mett.; Kuhn

Adiantum capillus-veneris L. 
Appendix 1. Continuation.

\section{SCIENTIFIC NAME}

Adiantum concinnum Humb. \& Bonpl. ex Willd.

Adiantum poiretii Wikstr.

Adiantum tenerum Sw.

Anogramma leptophylla (L.) Link

Astrolepis crassifolia (Houlston \& T.

Moore) D.M. Benham \& Windham

Astrolepis laevis (M. Martens \& Galeotti)

Mickel

Astrolepis sinuata (Lag. ex Sw.) D.M

Benham \& Windham

Cheilanthes bonariensis (Willd.) Proctor

Cheilanthes cucullans Fée

Cheilanthes eatonii Baker

Cheilanthes integerrima (Hook.) Mickel

Cheilanthes kaulfussii Kunze

Cheilanthes lendigera (Cav.) Sw.

Cheilanthes marginata Kunth

Cheilanthes microphylla Sw.

Cheilanthes tomentosa Link

Doryopteris palmata (Willd.) J. Sm.

Hemionitis palmata L.

Llavea cordifolia Lag.

Mildella intramarginalis Trevis.

Notholaena brachypus (Kunze) J. Sm.

Notholaena candida (M. Martens \&

Galeotti) Hook.

Pellaea ovata Weath.

Pellaea ternifolia (Cav.) Link

Pityrogramma calomelanos (L.) Link

Pityrogramma ebenea (L.) Proctor

Pityrogramma trifoliata (L.)

R.M. Tryon

Pteris altissima Poir.

Pteris cretica L.

Pteris grandifolia L.

Pteris orizabae M. Martens \& Galeotti

Pteris podophylla Sw.

Pteris pulchra Schltdl. \& Cham.

Pteris quadriaurita Retz.

Pterozonium brevifrons (A.C. Sm.)

Lellinger

PUTRANJIVACEAE

Drypetes lateriflora (Sw.) Krug \& Urb.

RANUNCULACEAE

Anemone mexicana Kunth

Clematis dioica L.

Clematis haenkeana C. PresI.

Consolida ambigua (L.) P.W. Ball

\& Heywood

Ranunculus aquatilis L.

Ranunculus dichotomus Moc. \&

Sessé ex DC.

Ranunculus macranthus Scheele

Ranunculus petiolaris Kunth

Ranunculus pilosus Kunth

Ranunculus praemorsus Kunth ex DC.

CITES NOM- 059 SCIENTIFIC NAME

CITES NOM- 059

Thalictrum galeottii Lecoy.

Thalictrum steyermarkii Standl.

Thalictrum strigillosum Hemsl.

RESEDACEAE

Forchhammeria trifoliata Radlk.

RHAMNACEAE

Ceanothus azureus Desf.

Colubrina arborescens (Mill.) Sarg.

Colubrina celtidifolia Schltdl.

Colubrina heteroneura (Griseb.) Standl.

Colubrina triflora Brongn.

Frangula capreifolia var. grandifolia (M.C.

Johnst. \& L.A. Johnst.) A. Pool

Frangula longistyla (C.B. Wolf.) A. Pool

Gouania lupuloides (L.) Urb.

Gouania polygama (Jacq.) Urb.

Rhamnus capreifolia Schltdl.

Sageretia elegans (Kunth) Brongn.

Ziziphus amole (Sessé \& Moc.) M.C. Johnst.

ROSACEAE

Acaena elongata L.

Agrimonia pringlei Rydb.

Alchemilla pectinata Kunth

Alchemilla pringlei (Rydb.) Fedde

Alchemilla procumbens Rose

Alchemilla sibbaldiifolia Kunth

Cercocarpus macrophyllus C.K. Schneid.

Cotoneaster lucidus Schltdl.

Crataegus mexicana Moc. \& Sessé ex DC.

Crataegus pubescens C. Presl

Duchesnea indica (Andrews) Teschem.

Eriobotrya japonica (Thunb.) Lindl.

Fragaria vesca L.

Holodiscus argenteus (L. f.) Maxim.

Holodiscus discolor (Pursh) Maxim.

Malacomeles denticulata (Kunth) G.N. Jones

Malus pumila Mill.

Potentilla aurea L.

Prunus brachybotrya Zucc.

Prunus cortapico Kerber ex Koehne

Prunus domestica L.

Prunus erythroxylon Koehne

Prunus matudae Lundell

Prunus persica (L.) Batsch

Prunus potosina Lundell

Prunus rhamnoides Koehne

Prunus samydoides Schltdl.

Prunus serotina Ehrh.

Prunus tetradenia Koehne

Pyracantha crenulata (D. Don) M. Roem.

Pyrus communis L.

Rosa roxburghii Tratt.

Rubus adenotrichos Schltdl.

Rubus coriifolius Liebm.

Rubus eriocarpus Liebm.

Rubus fagifolius Schltdl. \& Cham. 
Appendix 1. Continuation.

\section{SCIENTIFIC NAME}

Rubus liebmannii Focke

Rubus rosifolius Sm.

Rubus sapidus Schltdl.

Rubus schiedeanus Steud.

RUBIACEAE

Alibertia edulis (Rich.) A. Rich. ex DC.

Amaioua corymbosa Kunth

Arachnothryx capitellata (Hemsl.)

Borhidi

Arachnothryx gonzaleoides (Standl.)

Borhidi

Arachnothryx gracilispica (Standl.) Borhidi

Arachnothryx heteranthera (Brandegee)

Borhidi

Arachnothryx septicidalis (B.L. Rob.)

Borhidi

Augusta rivalis (Benth.) J.H. Kirkbr.

Borreria spinosa Cham. \& Schltdl.

Bouvardia laevis M. Martens \& Galeotti

Bouvardia ternifolia Schltdl.

Cephaelis elata Sw.

Chiococca alba Hitchc.

Chiococca pachyphylla Wernham

Chiococca phaenostemon Schltdl.

Chione venosa (Sw.) Urb.

Chione mexicana Standl.

Coccocypselum cordifolium Nees \& Mart.

Coccocypselum guianense (Aubl.)

K. Schum.

Coccocypselum herbaceum Aubl.

Coccocypselum hirsutum Bartl. ex DC.

Coffea arabica L.

Coutarea hexandra (Jacq.) K. Schum.

Crusea calocephala DC.

Crusea coccinea DC.

Crusea hispida (Mill.) B.L. Rob.

Crusea longiflora (Willd. ex Roem.

\& Schult.) W.R. Anderson

Deppea grandiflora Schltdl.

Deppea purpusii Standl.

Deppea umbellata Hemsl.

Didymaea alsinoides (Cham. \& Schltdl.)

Standl.

Diodella sarmentosa (Sw.) Bacigalupo

\& E.L. Cabral

Diodia teres Walter

Faramea occidentalis(L.) A. Rich.

Galianthe brasiliensis subsp. angulata

(Benth) E.L. Cabral \& Bacigalupo

Galium aschenbornii S. Schauer

Galium hypocarpium (L.) Endl. ex Griseb

Galium mexicanum Kunth

Galium orizabense Hemsl.

Genipa americana L.

Gonzalagunia panamensis (Cav.)

K. Schum.

Guettarda elliptica Sw.
CITES NOM- 059 SCIENTIFIC NAME

CITES NOM- 059

Guettarda macrocarpa Griseb.

Guettarda macrosperma Donn. Sm.

Hamelia patens Jacq.

Hedyotis exigula W.H. Lewis

Hedyotis microtheca Steud.

Hedyotis patens Ridl.

Hedyotis sharpii (Terrell) G.L. Nesom

Hillia tetrandra Sw.

Hoffmannia conzattii B.L. Rob.

Hoffmannia culminicola Standl. \&

L.O. Williams

Hoffmannia excelsa K. Schum.

Hoffmannia mexicana Hemsl.

Hoffmannia montana L.O. Williams

Hoffmannia orizabensis Standl.

Hoffmannia psychotriifolia Griseb.

Ixora coccinea L.

Margaritopsis microdon (DC.) C.M.

Taylor

Mexotis galeottii (M. Martens) Terrell

\& H. Rob

Mitracarpus hirtus DC.

Nertera granadensis Druce

Notopleura uliginosa Bremek.

Oldenlandia lancifolia DC.

Palicourea crocea (Sw.) Schult

Palicourea gardenioides Benth. \&

Hook. ex Hemsl.

Palicourea guianensis Aubl.

Palicourea macrantha Loes.

Palicourea padifolia ((Roem. \& Schult.)

T.N. Taylor \& Lorence

Pentas lanceolata (Forssk.) Deflers

Psychotria berteroana DC.

Psychotria capensis Vatke

Psychotria costivenia Griseb.

Psychotria elata (Sw.) Hammel

Psychotria flava Oerst. ex Standl.

Psychotria fruticetorum Standl.

Psychotria galeottiana (M. Martens)

C.M. Taylor \& Lorence

Psychotria Iorenciana C.M. Taylor

Psychotria mexiae Standl.

Psychotria panamensis Standl.

Psychotria papantlensis (Oerst.) Hemsl.

Psychotria pubescens Sw.

Psychotria quinqueradiata Pol.

Psychotria simiarum Standl.

Psychotria tenuifolia Sw.

Psychotria trichotoma M. Martens

\& Galeotti

Randia aculeata L.

Randia cookii Standl.

Randia monantha Benth.

Randia obcordata S. Watson

Randia xalapensis M. Martens

\& Galeotti 
Appendix 1. Continuation.

\section{SCIENTIFIC NAME}

Richardia scabra L.

Rogiera ligustroides (Hemsl.) Borhidi

Sabicea panamensis Wernham

Simira rhodoclada (Standl.) Steyerm.

Simira salvadorensis (Standl.) Steyerm.

Sommera arborescens Schltdl.

Spermacoce capitata Ruiz \& Pav.

Spermacoce remota Lam.

Spermacoce tetraquetra A. Rich.

Spermacoce verticillata $\mathrm{L}$.

Strumpfia maritima Jacq.

RUTACEAE

Amyris balsamifera L.

Amyris purpusii P. Wilson

Amyris sylvatica Jacq.

Casimiroa edulis La Llave

Choisya ternata Kunth

Citrus japonica Thunb.

Citrus maxima (Burm.) Merr.

Citrus medica L.

Citrus reticulata Blanco

Esenbeckia berlandieri Baill.

Esenbeckia dorantesii Ramos \&

E. Martínez

Esenbeckia macrantha Rose

Esenbeckia pentaphylla Griseb.

Murraya paniculata (L.) Jack

Peltostigma pteleoides (Hook.) Walp.

Ptelea trifoliata L.

Ruta graveolens L.

Stauranthus perforatus Liebm.

Zanthoxylum caribaeum Lam.

Zanthoxylum clava-herculis L.

Zanthoxylum elegantissimum P. Wilson

Zanthoxylum fagara Sarg.

Zanthoxylum juniperinum Poepp.

Zanthoxylum melanostictum Schltdl.

\& Cham.

Zanthoxylum riedelianum Engl.

SABIACEAE

Meliosma alba Walp.

Meliosma dentata Urb.

SACCOLOMATACEAE

Saccoloma inaequale (Kunze) Mett.

SALICACEAE

Abatia mexicana Standl.

Banara dioica Benth.

Casearia guevarana Cast.-Campos

\& E. Medina

Casearia guianensis (Aubl.) Urb.

Casearia nitida Jacq.

Casearia obovata Schltdl.

Casearia sylvestris Sw.

Lunania mexicana Brandegee

Pleuranthodendron lindenii (Turcz)

Sleumer

Populus alba L.
CITES NOM- 059 SCIENTIFIC NAME

CITES NOM- 059

Populus deltoidesW. Bartram ex

Marshall

Populus mexicana Wesm.

Salix babylonica L.

Salix bonplandiana Kunth

Salix exigua Nutt.

Salix humboldtiana Willd.

Salix interior var. angustissima

(Andersson) Dayton

Salix paradoxa Kunth

Salix taxifolia Kunth

Xylosma flexuosa (Kunth) Hemsl.

Xylosma panamensis Turcz.

Xylosma quichensis Donn. Sm.

Zuelania guidonia Britton \& Millsp.

SALVINIACEAE

Azolla filiculoides Lam.

SANTALACEAE

Phoradendron falcatum Eichler

Phoradendron galeottii Trel.

Phoradendron hexastichum (DC.) Griseb

Phoradendron nervosum Oliv.

Phoradendron pedicellatum (Tiegh.) Kuijt

Phoradendron piperoides (Kunth) Trel.

Phoradendron purpusii Trel.

Phoradendron quadrangulare (Kunth)

Krug \& Urb.

Phoradendron robinsonii Urb.

Phoradendron velutinum Nutt.

SAPINDACEAE

Cupania dentata Moc. \& Sessé

Cupania macrophylla Mart.

Cupania spectabilis Radlk.

Dodonaea viscosa Jacq.

Paullinia clavigera Schltdl.

Paullinia pinnata L.

Sapindus drummondii Hook. \& Arn.

Sapindus saponaria L.

Serjania brachycarpa A. Gray ex Radlk.

Serjania cardiospermoides Schltdl.

\& Cham.

Serjania glabrata Kunth

Serjania triquetra Radlk.

Thouinidium decandrum Radlk.

Urvillea ulmacea Kunth

SAPOTACEAE

Chrysophyllum mexicanum Brandegee ex Standl.

Manilkara zapota (L.) P Royen

Pouteria campechiana (Kunth) Baehni

Pouteria glomerata (Miq.) Radlk.

Pouteria rhynchocarpa T.D. Penn.

Sderoxylon capiri (A. DC.) Pittier

Sderoxylon persimile (Hemsl.) T.D. Penn

Sderoxylon salicifolium (L.) Lam.

SAXIFRAGACEAE

Heuchera acutifolia Rose 
Appendix 1. Continuation.

\begin{tabular}{|c|c|c|c|c|c|}
\hline SCIENTIFIC NAME & CITES & NOM- 059 & SCIENTIFIC NAME & CITES & NOM- 059 \\
\hline Heuchera mexicana W. Schaffn. ex Rydb. & & & Cestrum benthamii Miers & & \\
\hline SCHISANDRACEAE & & & Cestrum dumetorum Schltdl. & & \\
\hline Illicium floridanum J. Ellis & & & Cestrum elegans (Brongn. ex & & \\
\hline SCHOEPFIACEAE & & & Neumann) Schltdl. & & \\
\hline Schoepfia schreberi J.F. Gmel. & & & Cestrum endlicheri Miers & & \\
\hline SCROPHULARIACEAE & & & Cestrum fasciculatum Miers & & \\
\hline Buddleja parviflora Kunth & & & Cestrum Ianatum M. Martens \& Galeotti & & \\
\hline Buddleja skutchii C.V. Morton & & & Cestrum nocturnum L. & & \\
\hline Capraria biflora L. & & & Cestrum purpureum Standl. & & \\
\hline Capraria frutescens (Mill.) Britten & & & Cyphomandra betacea Cav. & & \\
\hline Verbascum virgatum Stokes & & & Cyphomandra hartwegii Sendtn. ex Walp. & & \\
\hline SELAGINELLACEAE & & & Datura meteloides DC. ex Dunal & & \\
\hline \& Grev.) Spring & & & altomata procumbens (Cav.) J.L. Gentry & & \\
\hline Selaginella martensii Spring & & & Lycianthes geminiflora Bitter & & \\
\hline Selaginella mollis A. Br. & & & Lycianthes lenta (Cav.) Bitter & & \\
\hline Selaginella pallescens (C. Presl) Spring & & & Lycianthes sideroxyloides Bitter & & \\
\hline Selaginella pulcherrima Liebm. & & & Lycopersicon esculentum Mill. & & \\
\hline Selaginella sartorii Hieron. & & & Nicandra physalodes (L.) Gaertn. & & \\
\hline Selaginella schiedeana A. Br. & & & Nicotiana plumbaginifolia Viv. & & \\
\hline Selaginella silvestris Aspl. & & & Nicotiana tabacum L. & & \\
\hline Selaginella stellata Spring & & & Physalis ampla Waterf. & & \\
\hline Selaginella stenophylla A. Braun & & & Physalis campanula Standl. \& Steyerm. & & \\
\hline SIMAROUBACEAE & & & Physalis gracilis Miers & & \\
\hline Picrasma mexicana Brandegee & & & Physalis greenmanii Waterf. & & \\
\hline Smilax mollis Humb. \& Bonpl. ex Willd. & & & Schraderanthus viscosus (Schrad.) Averett & & \\
\hline Smilax moranensis M. Martens \& Galeotti & & & Solandra guerrerensis Martinez & & \\
\hline Smilax spinosa Mill. & & & Solandra guttata D. Don & & \\
\hline SOLANACEAE & & & Solandra maxima (Sessé \& Moc.) & & \\
\hline Athenaea cernua Donn. Sm. & & & P.S. Green & & \\
\hline Brachistus stramoniifolius (Kunth) Miers & & & Solanum acerifolium Humb. \& & & \\
\hline Brugmansia suaveolens (Willd.) Bercht. & & & Bonpl. ex Dunal & & \\
\hline \& J. Presl & & & Solanum adhaerens Willd. ex Roem. & & \\
\hline Brugmansia $\times$ candida Pers. & & & \& Schult. & & \\
\hline Brunfelsia nitida Benth. & & & Solanum adscendens Sendthn. & & \\
\hline Capsicum annuum L. & & & Solanum aligerum Schltdl. & & \\
\hline Capsicum annuum var. aviculare & & & Solanum aphyodendron S. Knapp & & \\
\hline (Dierb.) D'Arcy \& Eshbaugh & & & Solanum appendiculatum Humb. \& & & \\
\hline Capsicum ciliatum Kuntze & & & Bonpl. ex Dunal & & \\
\hline Capsicum frutescens $\mathrm{L}$. & & & Solanum asperolanatum Ruiz \& Pav. & & \\
\hline $\begin{array}{l}\text { Capsicum lanceolatum (Greenm. Ex } \\
\text { Donn.Sm.) C.V. Morton \& Standl. }\end{array}$ & & & $\begin{array}{l}\text { Solanum aturense Humb. \& Bonpl. } \\
\text { ex Dunal }\end{array}$ & & \\
\hline Capsicum pubescens Ruiz \& Pav. & & & Solanum capsicoides All. & & \\
\hline Capsicum rhomboideum (Humb. & & & Solanum cervantesii Lag. & & \\
\hline Bonpl. \& Kunth) Kuntze & & & Solanum chrysotrichum Schltdl. & & \\
\hline Cestrum anagyris Dunal & & & Solanum diphyllum L. & & \\
\hline
\end{tabular}


Appendix 1. Continuation.

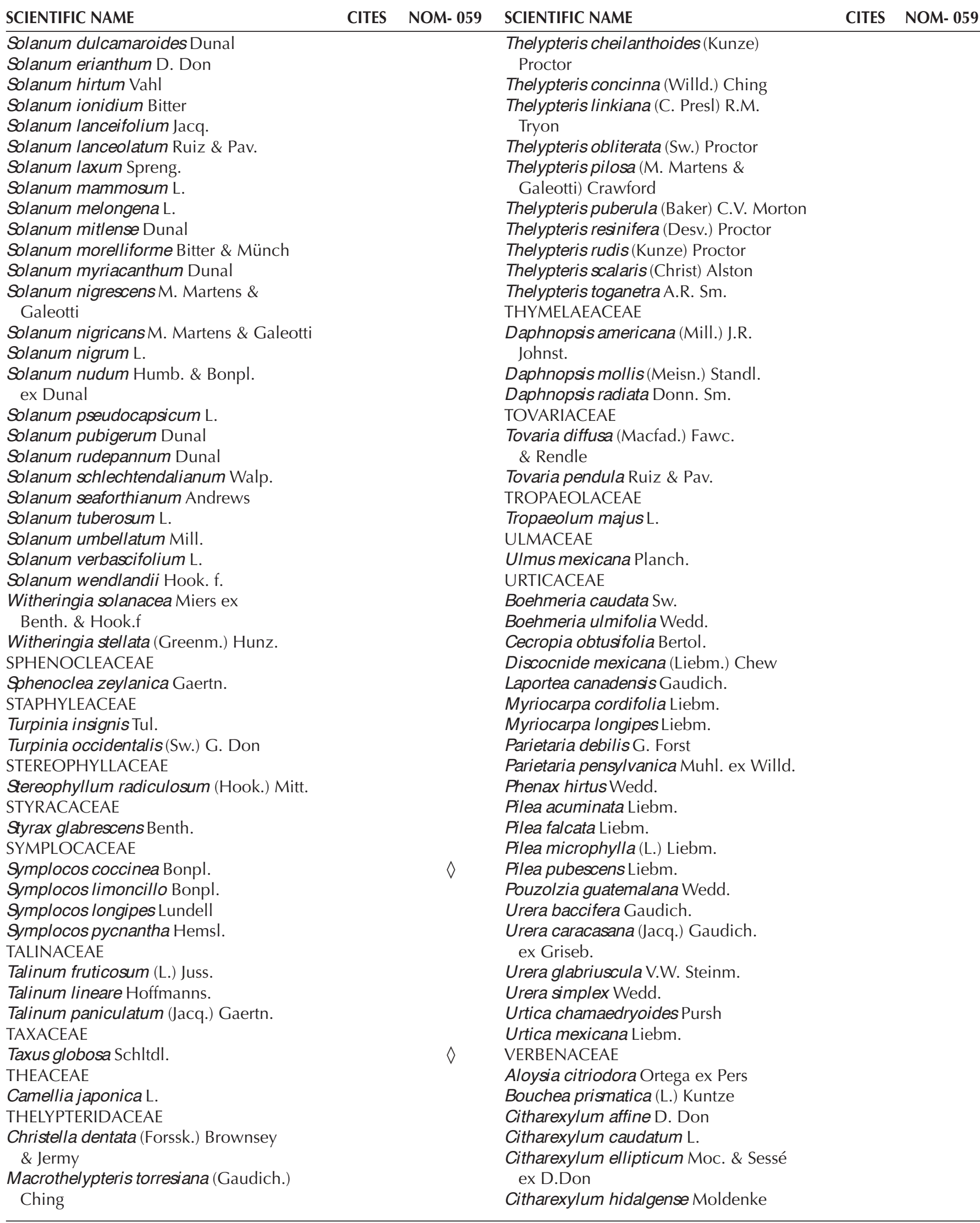


Appendix 1. Continuation.

\begin{tabular}{|c|c|c|c|c|c|}
\hline SCIENTIFIC NAME & CITES & NOM- 059 & SCIENTIFIC NAME & CITES & NOM- 059 \\
\hline Citharexylum ligustrinum Van Houtte & & & Viola jalapaensis W. Becker & & \\
\hline Citharexylum mocinnoi D. Don & & & Viola odorata L. & & \\
\hline Duranta erecta L. & & & Viola scandens Humb. \& Bonpl. ex Willd. & & \\
\hline Glandularia delticola (L.M.Perry) Umber & & & VITACEAE & & \\
\hline Glandularia elegans (Kunth) Umber & & & Ampelocissus erdvendbergiana Planch. & & \\
\hline Glandularia teucriifolia (M. Martens \& & & & Cissus alata Jacq. & & \\
\hline Galeotti) Umber & & & Cissus erosa Rich. & & \\
\hline Lantana camara L. & & & Cissus sicyoides L. & & \\
\hline Lantana canescens Kunth & & & Parthenocissus quinquefolia Planch. & & \\
\hline Lantana glandulosissima Hayek & & & Vitis berlandieri Planch. & & \\
\hline Lantana trifolia L. & & & Vitis biformis Rose & & \\
\hline Lantana velutina M. Martens \& Galeotti & & & Vitis bourgaeana Planch. & & \\
\hline Lippia alba (Mill.) N.E. Br. ex Britton & & & Vitis nesbittiana Comeaux & & \\
\hline \& P. Wilson & & & Vitis popenoei J.L. Fennell & & \\
\hline Lippia myriocephala Schltdl. \& Cham. & & & Vitis tiliifolia Humb. \& Bonpl. ex Schult. & & \\
\hline Lippia nodiflora Michx. & & & VITTARIACEAE & & \\
\hline Lippia umbellata Cav. & & & Polytaenium feei Maxon & & \\
\hline Petrea volubilis L. & & & Vittaria graminifolia Kaulf. & & \\
\hline Phyla scaberrima (Juss. ex Pers.) & & & WINTERACEAE & & \\
\hline Moldenke & & & Drimys winteri J.R. Forst. \& G. Forst & & \\
\hline Phyla strigulosa (M. Martens \& & & & WOODSIACEAE & & \\
\hline Galeotti) Moldenke & & & Athyrium filix-femina (L.) Roth & & \\
\hline Priva aspera Kunth & & & Woodsia mollis (Kaulf.) J.Sm. & & \\
\hline Stachytarpheta jamaicensis Vahl & & & XIMENIACEAE & & \\
\hline Tamonea curassavica (L.) Pers. & & & Ximenia americana L. & & \\
\hline Tectona grandis L. f. & & & ZAMIACEAE & & \\
\hline Verbena bipinnatifida Nutt. & & & Ceratozamia brevifrons Miq. & Appendix I & \\
\hline Verbena carolina L. & & & Ceratozamia mexicana Brongn. & Appendix I & $\diamond$ \\
\hline $\begin{array}{l}\text { Verbena ehrenbergiana S. Schauer } \\
\text { Verbena halei Small. }\end{array}$ & & & $\begin{array}{l}\text { Ceratozamia morettii Vázq. Torres \& } \\
\text { Vovides }\end{array}$ & Appendix I & $\diamond$ \\
\hline Verbena litoralis Kunth & & & Dioon edule Lindl. & Appendix II & $\diamond$ \\
\hline $\begin{array}{l}\text { Verbena longifolia M. Martens \& Galeotti } \\
\text { Verbena menthifolia Benth. }\end{array}$ & & & $\begin{array}{l}\text { Zamia inermis Vovides, J.D. Rees \& } \\
\text { Vázq. Torres }\end{array}$ & Appendix II & $\diamond$ \\
\hline Verbena pinetorum Moldenke & & & Zamia monticola Chamb. & Appendix I & \\
\hline Verbena rigida Spreng. & & & ZINGIBERACEAE & & \\
\hline VIOLACEAE & & & Alpinia zerumbet (Pers.) B.L. Burtt \& & & \\
\hline $\begin{array}{l}\text { Hybanthus attenuatus (Humb. \& Bonpl. } \\
\text { ex Schult.) Schulze-Menz }\end{array}$ & & & $\begin{array}{l}\text { R.M. Sm. } \\
\text { Hedychium coronarium J. Koenig }\end{array}$ & & \\
\hline Hybanthus elatus (Turcz.) C.V. Morton & & & Renealmia aromatica Griseb. & & \\
\hline Hybanthus mexicanus Ging. ex DC. & & & Renealmia mexicana Klotzsch ex Petersen & & \\
\hline Hybanthus parietariifolius Loes. & & & ZYGOPHYLLACEAE & & \\
\hline Rinorea guatemalensis Bartlett & & & Kallstroemia pubescens(G. Don) Dandy & & \\
\hline
\end{tabular}

